\title{
1 Seasonality and Oldowan behavioral variability in East Africa
}

2 Gonzalo J. Linares-Matás ${ }^{\mathrm{a}, *}$ \& James Clark ${ }^{\mathrm{b}}$

3 a St. Hugh's College, University of Oxford, St. Margaret's Road, Oxford, OX2 6LE, United 4 Kingdom

5 beverhulme Centre for Human Evolutionary Studies, University of Cambridge, Fitzwilliam 6 Street, Cambridge, CB2 1QH, United Kingdom

$7 \quad$ E-mail address: gonzalo.linaresmatas@ @t-hughs.ox.ac.uk (G. Linares-Matás).

8 Accepted for publication in Journal of Human Evolution (Decision made on 12-August-2021)

\section{Abstract}

10 The extent, nature, and temporality of early hominin food procurement strategies has been subject 11 to extensive debate. In this paper, we examine evidence for the seasonal scheduling of resource 12 procurement and technological investment in the Oldowan, starting with an evaluation of the 13 seasonal signature of USOs, freshwater resources, and terrestrial animal resources in extant 14 primates and modern human hunter-gatherer populations. Subsequently, we use the mortality 15 profiles, taxonomic composition, and taphonomy of the bovid assemblages at Kanjera South 16 (Homa Peninsula, Kenya) and FLK-Zinj (Olduvai Gorge, Tanzania) to illustrate the behavioral 17 flexibility of Oldowan hominins, who were targeting different seasonally-vulnerable 18 demographics. In terms of the lithic assemblages, the specific opportunities and constraints 19 afforded by dry season subsistence at FLK-Zinj may have disincentivized lithic investment, 20 resulting in a more expedient toolkit for fast and effective carcass processing. This may have been

21 reinforced by raw material site provisioning during a relatively prolonged seasonal occupation, 22 reducing pressures on the reduction and curation of lithic implements. In contrast, wet season plant 
23 abundance would have offered a predictable set of high-quality resources associated with low

24 levels of competition and reduced search times, in the context of perhaps greater seasonal mobility

25 and consequently shorter occupations. These factors appear to have fostered technological

26 investment to reduce resource handling costs at Kanjera South, facilitated by more consistent net

27 returns and enhanced planning of lithic deployment throughout the landscape. We subsequently

28 discuss the seasonality of freshwater resources in Oldowan procurement strategies, focusing on

29 FwJj20 (Koobi Fora, Kenya). While more analytical studies with representative sample sizes are

30 needed, we argue that inter-assemblage differences evidence the ability of Oldowan hominins to

31 adapt to seasonal constraints and opportunities in resource exploitation.

32 Keywords: Seasonality; Zooarcheology; Taphonomy; Lithic technology; Early Pleistocene; 33 Oldowan. 


\section{Introduction}

The Oldowan represents the first geographically and temporally widespread lithic tradition of the African Early Stone Age, and can be characterized by the removal of sharp (often short and thick) flakes from cores by direct percussion, with little secondary modification (Gallotti, 2018; Shea, 2020). Assemblages of this nature first appear around the beginning of the Early Pleistocene

39 ( 2.6-2.5 Ma) at Ledi-Geraru and Gona, Ethiopia (Semaw et al., 1997; Semaw et al., 2003; Braun 40 et al., 2019). Their appearance is correlated with a period of major climatic change in East Africa

41 (Plummer, 2004), as the gradual onset of the Northern Hemisphere Glaciation, particularly around $42 \sim 3.0-2.6 \mathrm{Ma}$, resulted in demonstrably cooler and more variable worldwide climates (e.g., Lisiecki 43 and Raymo 2005; Herbert et al., 2010; Joordens et al., 2019; Trauth et al. 2021). In Africa, this 44 process may have involved an expansion of grasslands and turnovers in mammalian faunas (e.g., 45 Vrba, 1985; deMenocal, 1995; Bobe and Behrensmeyer, 2004; deMenocal, 2004; Cerling et al., 46 2011; Potts, 2012; Potts and Faith, 2015), but these are likely to have been gradual and regionally47 distinct (Trauth et al., 2021). An important consequence of these changes is the evidence for an 48 intensification of yearly seasonality to levels comparable to the modern-day by at least $2 \mathrm{Ma}$ 49 (Blumenthal et al., 2019).

In many regions of East Africa, these patterns would imply the alternation of dry and wet

51 seasons, which can be identified directly at paleolake basin sites with intra-annual fluctuations in 52 water level, such as Olduvai Gorge (Beverly et al., 2014). Butzer (1982) argued that the strategic 53 location of hominin sites in mosaic environments with access to different resource patches would 54 have mediated the seasonal fluctuation of water and resources, with sites in the African interior 55 restricted to wetter climatic phases. In contrast, Speth (1987) proposed that the increasing 56 seasonality associated with the Plio-Pleistocene transition would have had crucial implications for 
57 hominin ecological fitness, requiring the development of adaptive subsistence strategies able to

58 successfully cope with the cyclical resource stress inherent to the food supply mechanisms of

59 hunter-gatherer and primate communities living in semi-arid landscapes. Ethnographic and

60 primatological studies attest to the notion that seasonal fluctuations in resource availability and

61 quality in subtropical environments have a considerable influence on the food-procurement

62 strategies and dietary composition of both modern human hunter-gatherers and non-human

63 primates (e.g., Speth, 1987; Hawkes et al., 1989; Marlowe and Berbesque, 2009; Lee, 2013; Oelze

64 et al., 2014). Recent approaches are showing that such seasonal variations also influenced hominin

65 diets (e.g., Sponheimer et al., 2005; Sponheimer et al., 2006; Joannes-Boyau et al., 2019).

Resource availability is not the only factor to consider for understanding the optimality of

67 hominin foraging strategies (cf., Hawkes et al., 1982; Foley, 1985; Kurland and Beckerman, 1985;

68 Ferraro, 2007). For example, even when an attractive resource is available in a given season, a

69 minimum level of landscape knowledge may be required for their consumption. Clark and Linares-

70 Matás (2020) define landscape knowledge as the extent to which a population is aware of the

71 distribution and predictability of specific resources within their unique habitat, suggesting that this

72 information determines the extent of engagement and technological investment in their

73 exploitation. This may explain why chimpanzees (Pan troglodytes) at Lopé Reserve, Gabon, do

74 not partake in nut-cracking, despite the bioavailability of nuts and the existence of suitable raw

75 materials (McGrew et al., 1997).

76 From the perspective of dietary breadth models, animals rank resources in their environment

77 by their nutritional rewards relative to search, procurement, and processing costs (Stephens and

78 Krebs, 1986; Kelly, 2013). Both high- and low-ranked plant and other non-mammalian resources

79 are likely to have been very important to hominin diets throughout human evolution, given their 
80 considerable contributions to primate and hunter-gatherer diets (Tanaka, 1976; Goodall, 1986;

81 Hawkes et al., 1989; Hawkes et al., 1995; Kitanishi, 1995; Marlowe and Berbesque, 2009; Melin

82 et al., 2014). Meat and within-bone resources, such as marrow, have a particularly high calorific

83 and nutritional potential (e.g., Bunn and Ezzo, 1993; Cordain et al., 2001; Tennie et al., 2009), and

84 thus are likely to have been an attractive resource for Early Pleistocene hominins. Evidence for

85 animal exploitation is often the best preserved direct evidence of Early Pleistocene subsistence,

86 with the appearance of the Oldowan penecontemporaneous with the first secure evidence for

87 hominin processing of animal remains ${ }^{1}$. This pattern is first documented at Gona and Bouri,

88 Ethiopia around 2.6-2.5 Ma (de Heinzelin et al., 1999; Domínguez-Rodrigo et al., 2005), and at

89 Ain Boucherit, Algeria, from 2.4 Ma (Sahnouni et al., 2018). Lithics are likely to represent an

90 adaptation for a faster and more efficient processing of particular resources available to hominins,

91 including the manufacture of organic implements (e.g., Isaac, 1986; Toth, 1987; Plummer, 2004;

92 Domínguez-Rodrigo et al., 2009; Gürbüz and Lycett, 2021).

93 Since certain primate genera are known to sporadically consume animal resources (Stanford,

94 2001; Surbeck and Hohmann, 2008; Watts, 2020), occasional omnivory was likely a basal hominin

95 trait (Stanford, 2012; Wood and Gilby, 2017). Nonetheless, meat is still a relatively marginal

96 dietary component in bonobos (Pan paniscus; Oelze et al., 2011), while chimpanzees only rarely

97 approach even the lowest levels of meat consumption seen in tropical hunter-gatherer societies

98 (Watts, 2020). Therefore, it is likely that several shifts towards greater emphasis on animal

99 consumption took place during the course of hominin evolution (Speth, 1989; Foley, 2001; Bunn,

100 2007; Domínguez-Rodrigo and Pickering, 2017; Thompson et al., 2019; Pobiner, 2020). This

\footnotetext{
${ }^{1}$ The earliest reported cut-marks in the archaeological record derive from Dikika, Ethiopia, from 3.39 Ma (McPherron et al., 2010), but their identification has been contested on taphonomic grounds (e.g., Domínguez-Rodrigo and Alcalá, 2016).
} 
101 increasing reliance on higher-quality resources may have driven brain growth and physiological 102 development (cf., Foley and Lee, 1991; Aiello and Wheeler, 1995). Resource provision may also 103 have influenced the life history strategies of hominins (e.g., Hawkes et al., 1997), facilitating the 104 required ontogenetic patterns for the development of increased neural complexity (cf., Hawkes and 105 Finlay, 2018).

106 We argue that seasonality is a critical framework for understanding hominin resource 107 procurement strategies in the Early Pleistocene of East Africa, as recently explored by Hosfield 108 (2020) in relation to the European Lower Paleolithic. In this paper, we first provide an overview 109 of the seasonal scheduling of resource consumption in relation to fluctuations in availability and 110 nutritional returns, with a view to generating hypotheses about the archaeological record. We 111 subsequently apply these insights to Oldowan subsistence strategies at Kanjera South and FLK112 Zinj, two crucial sites for understanding the nature of hominin access to animal resources (Bunn 113 and Pickering, 2010; Domínguez-Rodrigo et al., 2010; Blumenschine et al., 2012; Ferraro et al., 114 2013; Parkinson, 2013; Parkinson, 2018; Oliver et al., 2019). We argue that seasonal changes in 115 subsistence patterns and habitat selection would have profound implications for the predictability 116 of resource distributions across the landscape and their dietary returns, influencing the nature of 117 both food-procurement strategies and technological investment. We also discuss the seasonal 118 relevance of freshwater resources at Oldowan sites, particularly FwJj20, in terms of both their 119 potential contribution to hominin diets and as important paleoecological indicators. 

subtropical environments

There are a number of resources with seasonal fluctuations in availability which may have

123 been exploited by hominins, such as honey, insects (including colonial and soft-bodied

124 invertebrates), fruits and berries, roots and tubers, freshwater taxa, and terrestrial animal resources

125 (e.g., Bunn et al., 1988; Stewart, 1994; Sato et al., 2012; Lesnik, 2014; Marlowe et al., 2014; Melin

126 et al., 2014). Indeed, use-wear data on early bone technology from multiple South African Early

127 Pleistocene sites indicate extractive foraging through termite fishing or digging for roots and tubers

128 (Backwell and d'Errico, 2001; d'Errico and Backwell, 2009; Stammers et al., 2018). Here, we focus

129 our review on the importance for hominins of three resource types in particular: underground

130 storage organs (USOs), freshwater taxa, and terrestrial animal resources.

131 The consumption of terrestrial USOs, including roots and tubers, is relatively common

132 among certain chimpanzee communities, such as those of Ugalla and the Mahale Mountains,

133 Tanzania, during the wet season (Hernandez-Aguilar et al., 2007; Yoshikawa and Ogawa, 2015).

134 At Ugalla, this constitutes a period of low fruit availability (Hernandez-Aguilar et al., 2007). This

135 wet season bias for terrestrial USO consumption is also documented among human foragers in

136 tropical and subtropical environments, such as the Hiwi of the Venezuelan Amazon (Hurtado and

137 Hill 1990) and the Baka of southeastern Cameroon (Sato et al., 2012). This pattern may be linked

138 to lower procurement costs when the soil is softer, since the ground hardens during the dry season

139 and becomes more difficult to penetrate in certain environments (e.g., the savanna of Ugalla;

140 Hernandez-Aguilar et al., 2007). These acquisition costs may help to explain why the Aka of

141 northeastern Congo show lowest tuber exploitation in the late dry season, despite this being the

142 period where tubers are at their greatest size and return potential (Kitanishi, 1995). Among the 
143 Hadza of northern Tanzania, tubers may be brought to the camp in greatest quantities during the

144 wet season (Vincent, 1985; Marlowe and Berbesque, 2009), but procurement is fundamentally a

145 year-round foraging activity, with the number of foraging trips dependent on the seasonal

146 availability of preferred berries (Hawkes et al., 1989; Hawkes et al., 1995; Marlowe and

147 Berbesque, 2009). This pattern highlights that when higher-ranked resources have tightly-

148 constrained seasonal signatures, there is a need to adaptively schedule the consumption of different

149 resources to maintain nutritional quality throughout the year (Laden and Wrangham, 2005;

150 Lambert, 2007; Marshall and Wrangham, 2007; Marshall et al., 2009).

$151 \quad$ Freshwater fish represent one such seasonally-constrained but nutritious food source that

152 carnivores and non-human primates occasionally exploit (Turnbull-Kemp, 1967; Goodall, 1971;

153 Ewer, 1973; Kruuk, 1976; Hamilton and Tilson, 1985; Russon et al., 2014). Freshwater resources

154 are often an important source of essential polyunsaturated fatty acids and proteins for tropical and

155 subtropical hunter-gatherers, potentially playing an important role in human evolution (Broadhurst

156 et al., 2002; Jerardino and Marean, 2010; Joordens et al., 2014; Kyriacou et al., 2016).

157 Consumption of such resources may have emerged in the context of seasonal exploitation of USOs,

158 sedges, seedless vascular plants, and aquatic macrophytes in mosaic riparian environments (Sept,

159 1984; Wrangham et al., 2009; Stewart, 2010; Magill et al., 2016). For example, aquatic USOs

160 (which are not subject to the same soil hardness constraints as terrestrial USOs) are exploited by

161 yellow baboons (Papio cynocephalus), to the greatest extent during the dry season, when preferred

162 foods are scarce (Wrangham et al., 2009). The transition between the late dry and early wet seasons

163 is a particularly productive period in these environments for opportunistic human fishing (cf.,

164 Dufour, 1987; Sato et al., 2012). This is underpinned by a requirement for cognitive mapping of

165 seasonal fluctuations in water bodies, and knowledge requirements pertaining to specific seasonal 
166 fish behaviors in their habitual watercourses. In Eastern Africa, the late dry season is associated

167 with migratory catfish (Clarias spp.) and nesting Cichlidae becoming trapped and exposed in

168 shallow receding ponds (Leakey, 1971). In the early wet season, large quantities of catfish then

169 migrate upriver during the early rains to spawn (Greenwood, 1955), and some perciforms,

170 including cichlids, construct their nests in the shallows of river floodplains and lakes (Stewart,

171 1994). Since cichlids are very territorial, African fisher communities of the Bangwelu Wetlands

172 of northeastern Zambia often make spatial references on their recurrent nesting areas to ensure

173 successful fishing encounters during the wet season (Brelsford, 1946). Thus, fish could have been

174 a seasonally predictable and relatively easy to catch prey for Oldowan groups if they were able to

175 become acquainted with the location and fluctuations of seasonal lakes and streams.

176 On the other hand, primates and hunter-gatherer or fisher-forager groups also have the 177 opportunity to target certain freshwater resources, such as turtles, shellfish or migratory fish, 178 during the wider wet season, albeit at variable acquisition costs. Isolated instances of targeted wet 179 season acquisition of fish and crabs in shallow, slow-flowing waters have been documented among 180 long-tailed macaques (Macaca fascicularis) in Indonesia (Son, 2003; Stewart et al., 2008). Among 181 the Hiwi hunter-gatherers of Venezuela, the capture of freshwater turtles is predominantly carried 182 out during the late wet season, focused on the stable waters of oxbow lakes alongside river courses 183 (Hurtado and Hill, 1990). Indeed, a heavy wet-season bias in chelonid exploitation relative to 184 ungulate hunting by Kalahari San groups was used by Speth and Davis (1976) in one of the first 185 attempts to infer the seasonality of selected Early Pleistocene sites in East Africa.

186 Terrestrial animal resources present another dietary category particularly relevant to 187 discussions of the Early Pleistocene archeological record. There is much evidence for a seasonal 188 signature in chimpanzee hunting behaviors, but the same patterns are not consistently repeated 
between sites in different ecological settings (Mitani and Watts, 2005). Of particular relevance to

190 hominin behavior, chimpanzee hunting in open savanna environments focuses on the acquisition

191 of small vertebrates with low individual return rates (Pruetz et al., 2015; Moore et al., 2017). In

192 contrast, however, the targeting of larger animal carcasses is observed consistently within the

193 hominin lineage from the Early Pleistocene (Domínguez-Rodrigo et al., 2005; Braun et al., 2010;

194 Bunn and Pickering, 2010; Ferraro et al., 2013; Parkinson, 2018). As such, seasonal patterns of 195 meat availability and/or preference in modern human hunter-gatherers may provide clearer insights 196 about the intra-annual patterning of Oldowan food procurement strategies.

197 In the diets of many modern tropical and subtropical hunter-gatherer populations, animal 198 resources play a relevant role year-round, although meat consumption tends to be most frequent 199 during the dry season. For example, among the Baka, and the Mbuti of the Ituri Forest 200 (northeastern Congo), dry season procurement of mammals is consistently greater than during the 201 wet season (Ichikawa, 1983; Sato et al., 2012). Similarly, the greatest period of meat consumption 202 in the Hadza also occurs in the dry season, reaching $40 \%$ of food brought back to camp by weight 203 in the late dry, and dropping to as little as $\sim 10 \%$ during the early wet (Marlowe and Berbesque, 204 2009). Among the Ju/'hoansi, Botswana, this general pattern is replicated, with meat also observed 205 to provide up to $80 \%$ of the diet during two months of one particularly severe dry season, when all 206 other resources were rather scarce (Weissner and N!aici, 1998; Lee, 2013). This pattern is likely 207 to result from the interplay between changes to overall resource abundance and to resource quality 208 and ranking by season.

209 The reduction of plant availability and the evaporation of rain-fed seasonal watercourses 210 during the dry season in in arid and semi-arid regions of Africa often leads to the concentration of 211 weakened herbivores around the few permanent water sources still present in the landscape, as 
212 these animals require access to forage persisting around these areas as well as drinking water to 213 compensate for the dehydration of plant foods (Thrash et al., 1995; Redfern et al., 2003; Chamaille-

214 Jammes et al., 2008; Valeix 2011). This spatial clustering of hunting and scavenging opportunities

215 ensures that predators do not need to spend as much time searching for prey in the dry season, and 216 have a greater success rate in locating them (Bunn et al., 1988; Hurtado and Hill, 1990; Foley, 217 1993; O'Connell et al., 2002; Hawkes, 2016). These animal resources also have a greater dietary 218 return than most individual available plants, which further encourages a shift towards their 219 procurement (Pobiner, 2015). This ecological pattern can help explain why most meat tends to be 220 consumed by the Hadza and other subtropical hunter-gatherers during the dry season, providing a 221 greater dietary contribution in the face of seasonal and inter-annual fluctuations in plant resource 222 availability (Vincent, 1985; Bunn et al., 1988; Hitchcock, 1989; Hawkes et al., 1991; O’Connell 223 et al., 1992; Hawkes et al., 1997; Sherry and Marlowe, 2006; Marlowe and Berbesque, 2009; Lee, 224 2013).

225 At the same time, modern human populations have a limit for protein consumption of around $226 \quad 30-40 \%$ of dietary calories, with consumption above this threshold exceeding the body's ability 227 to metabolize urea (Cordain et al., 2000). As a result, repeated consumption of lean meat results 228 in a breach of the 'protein ceiling' - which may lead to protein poisoning — thus placing relatively 229 tight constraints on its consumption and rendering it an ineffective resource under food stress 230 conditions (Binford, 1978; Speth, 1983; Cordain et al., 2000). Indeed, a pattern of fat-depleted 231 animal avoidance is documented among hunters in semi-arid environments, who may even 232 abandon whole carcasses if they are too lean (Tindale, 1972; Hayden, 1981; Speth, 1983). In a 233 similar fashion, contemporary African fishers may throw fat-depleted fish back to the water 234 (Brelsford, 1946; Jubb, 1967). 
In contexts of marginal nutritional intake, fat and especially carbohydrates, have a protein-

236 sparing effect, as the body is also able to derive energy from these non-protein sources, thus

237 reducing the metabolic demands associated with amino acid catabolism (Munro, 1964; Richardson

238 et al., 1979; Speth and Spielmann, 1983; Bunn and Ezzo, 1993). During periods of fat-depletion

239 in animal carcasses, Cordain et al. (2000) suggest that hunter-gatherers must either show a

240 preferential selection for fattier individuals or carcass portions, hunt larger animals with greater

241 proportions of body fat, or increase their consumption of plant resources, particularly those with

242 high carbohydrate concentrations. A general preferential selection of fattier animals is reported by

243 many different hunter-gatherer groups across different ecosystems (Tomita, 1966; Hart and Hart,

244 1986; O’Dea et al., 1991). In particular, the hunting of different duiker (Cephalophus spp.) species

245 predominantly during the dry season by the Mbuti corresponds to the only period of the year when

246 these animals store substantial mesentery fat, as reflected in high kidney fat index (KFI) values

247 (Ichikawa, 1983; Hart and Hart, 1986). Similarly, Lee (2013) reports that the Ju/'hoansi make their

248 first cut of an ungulate carcass along the breastbone, in order to first check the extent of

249 subcutaneous fat, and gain access to the viscera. This preference for fatty body parts is even a

250 common finding among chimpanzees (e.g., Boesch and Boesch, 1989; Pruetz et al., 2015). For

251 example, Gilby and Wawrzyniak (2018) report that chimpanzee consumption of primate prey at

252 Gombe follows a predictable pattern based on immediate returns, in which energy-dense, fat-rich

253 resources, such as viscerae and head-contents, were usually exploited first. This body of evidence

254 strongly suggests that one of the main attractions of animal carcasses for human and non-human

255 primates is fat-rich tissue (Hayden, 1981; Hill et al., 1984; Lee, 2013). Therefore, the interplay

256 between physiological constraints and prey selection strategies makes body fat fluctuation a 
257 critical aspect for modelling seasonal patterns of terrestrial ungulate consumption in the Early

258 Pleistocene (Speth, 1987; Bunn and Ezzo, 1993; Cordain et al., 2000; Ben-Dor et al., 2011).

259 As the dry season advances, the reduction in the quality and distribution of food resources

260 leads to declines in body fat percentage among terrestrial ungulates (Speth, 1987). In modern

261 African savannas, ungulates try to mitigate these trends through the deployment of seasonal dietary

262 and mobility strategies that play a considerable role in regulating their abundance and population

263 dynamics (Staver and Hempson, 2020). Ungulates of the Serengeti ecosystem (northern Tanzania)

264 tend to subsist on sub-maintenance diets for most of the dry season, using the consumption of large

265 amounts of low-quality forage as a way to slow the rate of utilization of their internal fat reserves

266 (Sinclair, 1975). This pattern leads to a time lag between the point of lowest total caloric intake

267 and the point of poorest condition (i.e., nutritional yield) of African ungulates (Sinclair, 1975;

268 Speth, 1983). Total carcass fat is therefore at its lowest around the end of the dry season and the

269 beginning of the rainy season (Speth, 1987).

270 This time lag in ungulate physiology therefore has paramount implications for understanding

271 the impact of seasonal food stress on Oldowan animal food procurement strategies, since it implies

272 that the quality of animal resources will have declined less rapidly than that of plant resources in

273 the dry season (Bunn and Ezzo, 1993). As such, we expect hominin consumption of meat resources

274 to be greater during most of the dry season, excluding the very late dry. In the early wet season,

275 ungulate carcasses would still exhibit a high degree of fat-depletion. Moreover, terrestrial

276 ungulates tend to disperse in the face of wider plant biomass availability with the onset of the rains,

277 resulting in lower encounter rates. At this time of the year, hominins should have therefore

278 preferentially targeted carbohydrate-rich resources (berries, honey, and tubers), and energy-dense

279 fatty resources, such as freshwater species or the brains, viscerae, and marrow of terrestrial 
280 ungulates, alongside any protein intake (Table 1). Towards the second half of the wet season, we

281 would expect animal carcasses to regain their overall nutritional attractiveness, although their

282 dispersed pattern would entail higher search costs.

\begin{tabular}{|c|c|c|c|c|c|}
\hline \multirow[t]{2}{*}{ Resource } & & \multicolumn{3}{|c|}{ Seasonal Preferences } & \multirow[t]{2}{*}{ References } \\
\hline & & Dry season & $\begin{array}{l}\text { Very late dry to early } \\
\text { wet transition }\end{array}$ & $\begin{array}{c}\text { Wet } \\
\text { season }\end{array}$ & \\
\hline \multirow[t]{2}{*}{$\begin{array}{l}\text { Underground storage } \\
\text { organs (USOs) }\end{array}$} & Terrestrial & Moderate & Moderate & High & $\begin{array}{l}\text { Hawkes et al. (1989, 1995); } \\
\text { Kitanishi (1995); Hernandez- } \\
\text { Aguilar et al. (2007); Marlowe } \\
\text { and Berbesque (2009); Sato et } \\
\text { al. (2012) }\end{array}$ \\
\hline & Aquatic & High & Moderate & Low & $\begin{array}{c}\text { Laden and Wrangham (2005); } \\
\text { Wrangham et al. (2009); } \\
\text { Stewart (2010) }\end{array}$ \\
\hline Freshwater resources & & Low & High & Moderate & $\begin{array}{l}\text { Leakey (1971); Speth and } \\
\text { Davis (1976); Stewart (1994) }\end{array}$ \\
\hline \multirow[t]{2}{*}{$\begin{array}{l}\text { Terrestrial animal } \\
\text { resources }\end{array}$} & $\begin{array}{l}\text { Meat and } \\
\text { marrow }\end{array}$ & High & Low & Moderate & $\begin{array}{l}\text { Sinclair (1975); Speth and } \\
\text { Davis (1976); Blumenschine } \\
\text { (1987); Bunn et al. (1988); } \\
\text { Blumenschine and Madrigal } \\
\text { (1993); Bunn and Ezzo (1993) }\end{array}$ \\
\hline & $\begin{array}{l}\text { Viscerae and } \\
\text { head contents }\end{array}$ & Moderate & High & Moderate & $\begin{array}{l}\text { Bunn and Ezzo (1993); Speth } \\
\text { and Spielmann (1983); } \\
\text { Cordain et al. (2000); Gilby } \\
\text { and Wawrzyniak (2018) }\end{array}$ \\
\hline
\end{tabular}

283 Table 1: Hypothesized seasonal preferences (based on resource availability, constraints, and 284 returns) for the main set of resources discussed in the text for Oldowan hominins.

285 Lastly, we recognize the additional importance of inter-annual differences in the magnitude

286 of fluctuations in resource quality and availability, and that these changes may limit our ability to

287 confidently infer seasonality (e.g., Hawkes et al., 1991; Speth et al., 1991). Nonetheless, we

288 propose that the intra-annual framework outlined here can still be broadly applied to the

289 characterization of hominin adaptation to recurrent terrestrial animal resource variability, with

290 seasonality being a key driver of this pattern at the yearly scale. 


\section{Carcass acquisition strategies by Oldowan hominins}

\subsection{Hunting versus scavenging debate}

Early paleoanthropological research was quick to take for granted that hunting was a 294 quintessential activity of early Homo, driving their socio-economic and technological organization

295 (cf., Lee and DeVore, 1968). Glynn Isaac's (1978; Isaac, 1984) work contributed to the shift of 296 emphasis towards the underlying social organization, structured through cooperation, a gendered 297 division of labor, and the subsequent sharing of food resources at home bases. This period also 298 witnessed the first detailed zooarcheological and taphonomic research on Early Pleistocene faunal 299 remains as sources of evidence (Behrensmeyer, 1978; Bunn et al., 1980; Binford, 1981; Bunn, 300 1981; Potts and Shipman, 1981). When Binford (1985) analyzed skeletal part profiles and 301 superficially assessed the nature of bone surface modifications at FLK-Zinj, he concluded that 302 hominins appeared to have been marginal scavengers of carnivore kills. This interpretation 303 fostered actualistic research assessing whether hominin exploitation of abandoned carnivore kills 304 could have represented a reliable source of nutrients (Blumenschine, 1986; Blumenschine, 1987; 305 Blumenschine, 1988; Domínguez-Rodrigo, 1994; Domínguez-Rodrigo, 1999; Pobiner, 2015).

306 However, subsequent taphonomic and actualistic research amongst modern hunter-gatherers 307 highlighted the relevance of an abundant representation of high-yielding skeletal parts bearing 308 anthropogenic modifications, such as cut-marks and percussion marks, for identifying stone-tool 309 mediated butchery at FLK-Zinj and Koobi Fora sites (e.g., Bunn, 1986; Bunn and Kroll, 1986; 310 Shipman, 1986; Bunn et al., 1988; O’Connell et al., 1988a; O’Connell et al., 1992).

311 The interpretation of the abundance, anatomical distribution, and overlap between bone 312 surface modifications (cut-marks, percussion marks, and carnivore tooth marks) on mammal bones 313 became the next major avenue of taphonomic and actualistic research (Blumenschine et al., 1994; 
314 Domínguez-Rodrigo, 1994; Domínguez-Rodrigo, 2001). Several researchers have concluded that

315 the tooth mark and percussion marks counts reported by Blumenschine et al. (1994) for FLK-Zinj

316 fit a carnivore-hominin-carnivore model — whereby hominins scavenged carcasses abandoned by

317 large felids, with bones subsequently ravaged by hyenids (Blumenschine, 1995; Capaldo, 1997;

318 Pante et al., 2015). Nonetheless, a considerable proportion of the tooth-marks reported in

319 Blumenschine et al. (1994) have been subsequently reassessed as having a natural biochemical

320 origin unrelated to carnivore activity (Domínguez-Rodrigo and Barba, 2006; Parkinson, 2018).

321 The pattern resulting from the new tooth mark estimates better fits Blumenschine's hammerstone-

322 to-carnivore model, indicating primary access of hominins to carcasses, either by hunting or

323 confrontational scavenging, followed by secondary carnivore scavenging (Domínguez-Rodrigo

324 and Barba, 2006). This revision is also more consistent with the anatomical placement and

325 frequency of cut-marks and percussion marks (Bunn and Kroll, 1986; Bunn and Ezzo, 1993;

326 Parkinson, 2013; Parkinson, 2018). Early access to carcasses following a hominin-first model has

327 also been reported for other Oldowan sites, including DS (Olduvai Bed I; Cobo-Sánchez, 2020)

328 and Kanjera South (Ferraro et al., 2013; Parkinson, 2013), and can therefore be considered a 329 relevant feature of Early Pleistocene hominin dietary behaviors.

330 At the same time, portraying early hominin carcass acquisition as an either/or dichotomy

331 between the hunting of prime game and the scavenging of carnivore leftovers is likely misplaced

332 (cf., Bunn and Kroll, 1986; Blumenschine, 1987; Potts, 1988). Indeed, insights from carnivore

333 ethology suggest that most predators engage to an extent in both hunting and opportunistic

334 scavenging by adaptively responding to seasonal fluctuations in prey distribution, prey body

335 condition, and carrion availability, with the selected strategy reflecting an ecological trade-off

336 between energetic investment and dietary output (Molinari-Jobin et al., 2004; Owen-Smith, 2008; 
337 Pereira et al., 2014; Mattison et al., 2016). The Hadza provide a hunter-gatherer example of this

338 phenomenon, as individuals are able to respond quickly to scavenging opportunities, including

339 passive scavenging of within-bone nutrients, when they appear at localities where they actively

340 capture ungulate prey (Bunn et al., 1988; O'Connell et al., 1988b; O'Connell et al., 2002; Hawkes,

341 2016). We suggest that Oldowan hominins were also likely to have displayed the flexibility

342 required to switch between different carcass acquisition and processing strategies (Speth, 1983;

343 Bunn and Ezzo, 1993), particularly when facilitated by the deployment of lithic technologies

344 (Foley, 1985; Ferraro, 2007).

345

346 3.2. Seasonality, prey selection, and carcass acquisition strategies

347 There are several possible methods of acquiring animal carcasses: scavenging the remains

348 of animals that have died naturally or through predation (passive scavenging), 'kleptoparasitism'

349 (confrontational/power scavenging) whereby predators are actively chased away from their kills,

350 'compensatory/cursorial predation' of individuals already vulnerable to death due to age or

351 disease, and 'additive predation' of healthy individuals (Schaller and Lowther, 1969; Schaller,

352 1972; Pereira et al., 2014). These strategies are summarized in Table 2 (passive scavenging has

353 been divided into facultative scavenging - feeding on earlier predator kills — and scavenging of

354 natural death pulses), alongside their respective ecological patterning and archeological signatures

355 as a framework for evaluating Pleistocene sites. We recognize that these discrete categories

356 actually fall along an overlapping behavioral continuum of carcass acquisition behavior, and

357 therefore hominins are likely to have employed these strategies at different points in time and in

358 varying frequencies, depending on the potential returns, costs, and constraints in a given context. 
Seasonality has a profound influence on these decision variables, due to changes in factors

360 such as soil condition, maximum daily temperature, cloud cover, precipitation, animal

361 physiological condition, and prey densities. A wide range of carnivores and human-hunter-

362 gatherers adopt compensatory prey selection strategies that are intrinsically linked to these

363 predictable intra-annual changes. For example, lions (Panthera leo) of Hwange National Park,

364 Zimbabwe, preferentially target buffalo (Syncerus caffer) year-round, but males show an increase

365 in the hunting of vulnerable juveniles when they become more abundant during the wet season

366 (Davidson et al., 2013). Furthermore, lions opportunistically exploited a range of other seasonally-

367 vulnerable animals, including juvenile elephants taken during very late dry season droughts

368 (Davidson et al., 2013). Leopards (Panthera pardus) also actively adapt their prey selection

369 strategies to take advantage of birthing seasons and ecosystem changes (Karanth and Sunquist,

370 1995; Yang et al., 2018).

371 Bunn and Ezzo (1993) argued that a flexible adoption of carcass procurement strategies

372 based on intra-annual body condition variability could have provided hominins with a suitable

373 supply of animal resources at different points of the year. Ethnographic accounts of hunting

374 strategies by San groups in the Kalahari demonstrate a pattern of seasonally-vulnerable ungulate

375 prey selection, targeting animals more prone to tiredness on the basis of attributes that fluctuate

376 over different temporal scales such as reproductive status, age, injury, illness, hunger, or thirst. For

377 example, !Xo and G/wi hunters of the Kalahari choose to pursue certain Bovidae, such as steenbok

378 (Raphicerus campestris), common duiker (Sylvicapra grimmia) and gemsbok (Oryx gazella),

379 during the rainy season, when the wet sand forces open their hoofs and stiffens the joints (Schapera,

380 1930; Liebenberg, 2006). In the dry season, Kalahari hunters prefer to track greater kudu

381 (Tragelaphus strepsiceros), eland (Taurotragus oryx), and red hartebeest (Alcelaphus caama) 
382 males with heavy horns or pregnant females, who become exhausted faster when running on loose 383 sand (Liebenberg 2006). In each case, the hunters identify and follow trails of isolated weaker 384 individuals, who are exhausted and have splintered from the rest of the herd to hide in the bush 385 (Liebenberg, 2006). The nature and temporality of carcass acquisition strategies determine the specific animal 387 nutrients and skeletal parts available to Oldowan hominins at any given site (Schaller and Lowther, 388 1969; Bunn and Ezzo, 1993). We can predict a focus on high-ranking (and fatty) viscerae whenever 389 hominins had primary access to the carcass (e.g., Lee 2013; Gilby and Wawrzyniak, 2018), most 390 clearly documented through cut-marks on the ventral side of ribs (cf., Nilsson, 2000). This would 391 have been particularly important to hominins during seasonal fat-depletion in terrestrial ungulate 392 carcasses (very late dry to early wet transition), where meat itself becomes very lean. Other 393 elements with high fat availability that are often left by large felids, such as head contents or the 394 marrow of limb bones (Pobiner, 2015), are likely to have been favored whenever available, 395 regardless of the timing of access to the carcass (Thompson et al., 2019). This pattern may have 396 been exacerbated seasonally, with focus shifting towards bones that retain the greatest overall 397 amounts of fat, such as the tibiae, or those which deplete more slowly, such as the lower limb 398 bones (Newlin and McCay, 1948; Turner, 1979; Speth, 1987; Speth, 1990; Blumenschine and 399 Madrigal, 1993). 


\begin{tabular}{|c|c|c|c|c|c|c|c|c|}
\hline Strategy & $\begin{array}{c}\text { Trophic } \\
\text { engagement }\end{array}$ & $\begin{array}{l}\text { Access to } \\
\text { carcass }\end{array}$ & Returns & $\begin{array}{l}\text { Procurement } \\
\text { costs }\end{array}$ & $\begin{array}{c}\text { Planning } \\
\text { requirements }\end{array}$ & $\begin{array}{c}\text { Mortality } \\
\text { profiles }\end{array}$ & $\begin{array}{l}\text { Taphonomic } \\
\text { signature }\end{array}$ & $\begin{array}{c}\text { Relevant Oldowan } \\
\text { references }\end{array}$ \\
\hline $\begin{array}{l}\text { Facultative } \\
\text { scavenging }\end{array}$ & Passive & Secondary & $\begin{array}{l}\text { Meat scraps and } \\
\text { within-bone } \\
\text { nutrients }\end{array}$ & $\begin{array}{l}\text { Low: late access } \\
\text { to carcasses } \\
\text { reduces initial } \\
\text { competition }\end{array}$ & Low & $\begin{array}{l}\text { Representative of } \\
\text { primary } \\
\text { carnivore(s) }\end{array}$ & $\begin{array}{l}\text { Abundant tooth- } \\
\text { marks } \\
\text { Cut-marks on low- } \\
\text { ranking parts }\end{array}$ & $\begin{array}{l}\text { Binford (1981); Blumenschine } \\
\text { (1987); Pante et al. (2012) }\end{array}$ \\
\hline $\begin{array}{l}\text { Scavenging of } \\
\text { natural death pulses }\end{array}$ & Passive & Primary & $\begin{array}{l}\text { Multiple whole } \\
\text { carcasses } \\
\text { Poor } \\
\text { physiological } \\
\text { condition }\end{array}$ & $\begin{array}{l}\text { Low- } \\
\text { Intermediate: } \\
\text { competition can } \\
\text { be high }\end{array}$ & $\begin{array}{l}\text { Low- } \\
\text { Intermediate: } \\
\text { predictable } \\
\text { carrion pulses }\end{array}$ & $\begin{array}{l}\text { Attritional, } \\
\text { occasionally } \\
\text { catastrophic }\end{array}$ & $\begin{array}{l}\text { Mass nearby } \\
\text { concentration of } \\
\text { natural deaths } \\
\text { Emphasis on } \\
\text { evisceration and } \\
\text { within-heads } \\
\text { contents }\end{array}$ & $\begin{array}{l}\text { Capaldo and Peters (1995); } \\
\text { Lam (2008) }\end{array}$ \\
\hline $\begin{array}{l}\text { Confrontational } \\
\text { scavenging }\end{array}$ & Passive & Early & $\begin{array}{l}\text { Near-complete } \\
\text { carcasses }\end{array}$ & $\begin{array}{l}\text { Intermediate: } \\
\text { involves } \\
\text { carnivore } \\
\text { encounters }\end{array}$ & $\begin{array}{c}\text { Intermediate: } \\
\text { anticipation of } \\
\text { carnivore } \\
\text { behavior and } \\
\text { chasing away }\end{array}$ & $\begin{array}{l}\text { Representative of } \\
\text { primary } \\
\text { carnivore(s) }\end{array}$ & $\begin{array}{l}\text { Low evisceration cut- } \\
\text { mark counts } \\
\text { High-incidence of } \\
\text { defleshing cut-marks }\end{array}$ & $\begin{array}{l}\text { Medium to large carcasses: } \\
\text { Bunn and Ezzo (1993); Bunn } \\
\text { (2001); O’Connell et al. (2002) }\end{array}$ \\
\hline $\begin{array}{l}\text { Compensatory } \\
\text { hunting }\end{array}$ & Active & Primary & $\begin{array}{l}\text { Complete } \\
\text { carcasses }\end{array}$ & High & High & $\begin{array}{l}\text { Seasonally } \\
\text { vulnerable } \\
\text { demographics }\end{array}$ & $\begin{array}{l}\text { Evisceration and } \\
\text { defleshing cut-marks }\end{array}$ & $\begin{array}{c}\text { Small Carcasses: Bunn and } \\
\text { Pickering (2010); Oliver et al. } \\
\text { (2019) }\end{array}$ \\
\hline Additive hunting & Active & Primary & $\begin{array}{l}\text { Complete } \\
\text { carcasses }\end{array}$ & Highest & Highest & Prime adults & $\begin{array}{c}\text { Evisceration and } \\
\text { defleshing cut-marks }\end{array}$ & $\begin{array}{l}\text { Medium to large carcasses: } \\
\text { Bunn and Pickering (2010); } \\
\text { Bunn and Gurtov (2014) }\end{array}$ \\
\hline
\end{tabular}

401 Table 2: Profile of different possible carcass acquisition strategies available to Oldowan hominins. Procurement costs include those

402 incurred while procuring the carcass, its processing, and its defense. 
403 The availability of certain terrestrial animal nutrients and skeletal parts to Early Pleistocene

404 hominins would have nonetheless been partially reliant on the carcass acquisition strategies

405 followed (Table 2). Thus we can predict an initial focus on viscerae, whenever hominins had

406 primary access to the carcass, as well as the head contents and within-bone nutrients of skeletal

407 elements with high marrow contents at that time (such as the tibiae) and/or those with delayed

408 depletion (such as the lower limb bones), regardless of carcass acquisition strategy (Newlin and

409 McCay, 1948; Turner, 1979; Speth, 1987; Speth, 1990; Blumenschine and Madrigal, 1993). As

410 such, we hypothesize that dry season Oldowan sites may show a greater dependence on animal

411 tissue, with most parts of the carcass (including meat) providing an attractive resource (cf.,

412 Blumenschine, 1987; Bunn et al., 1988; Bunn and Ezzo, 1993). On the other hand, during periods

413 of greatest ungulate physiological stress (most commonly the very late dry season and the early

414 wet season), we would expect to see an increased emphasis on skeletal parts that retain the greatest

415 proportions of fatty nutrients (cf., Cordain et al., 2000). For example, the fat contents of brain and

416 viscerae, particularly the liver, remain relatively constant throughout the year, while adipose tissue

417 mass and bone marrow gradually become depleted under conditions of nutritional stress (Cordain

418 et al., 2002; Kuipers et al., 2010). Nonetheless, the marrow of distal appendicular bones,

419 particularly metapodials - which contain the highest proportion of digestible low-melting-point

420 fatty acids - tends to become depleted last among ungulates (Speth, 1987; Blumenschine and 421 Madrigal, 1993). 


\section{Seasonally-mediated behavioral variability at Kanjera South and FLK-Zinj}

423 Carcass acquisition strategies at Early Pleistocene sites are frequently assessed

424 taphonomically, but limited faunal preservation or a lack of a clear association with co-occurring 425 lithic assemblages often prevent an accurate assessment of hominin behavior (Domínguez426 Rodrigo, 2009). Nonetheless, it may be possible to demonstrate a relationship between resource 427 exploitation strategies, seasonality, and the nature of lithic assemblages at certain Oldowan sites, 428 such as Kanjera South, Kenya (2.0 Ma), and FLK-Zinj (FLK Level 22), Olduvai Gorge, Tanzania 429 (1.84 Ma; Bunn, 1981; Bunn and Ezzo, 1993; de la Torre and Mora, 2005; Braun et al., 2009b; 430 Domínguez-Rodrigo, 2009; Ferraro et al., 2013; Parkinson, 2013; Oliver et al., 2019; Figure 1).

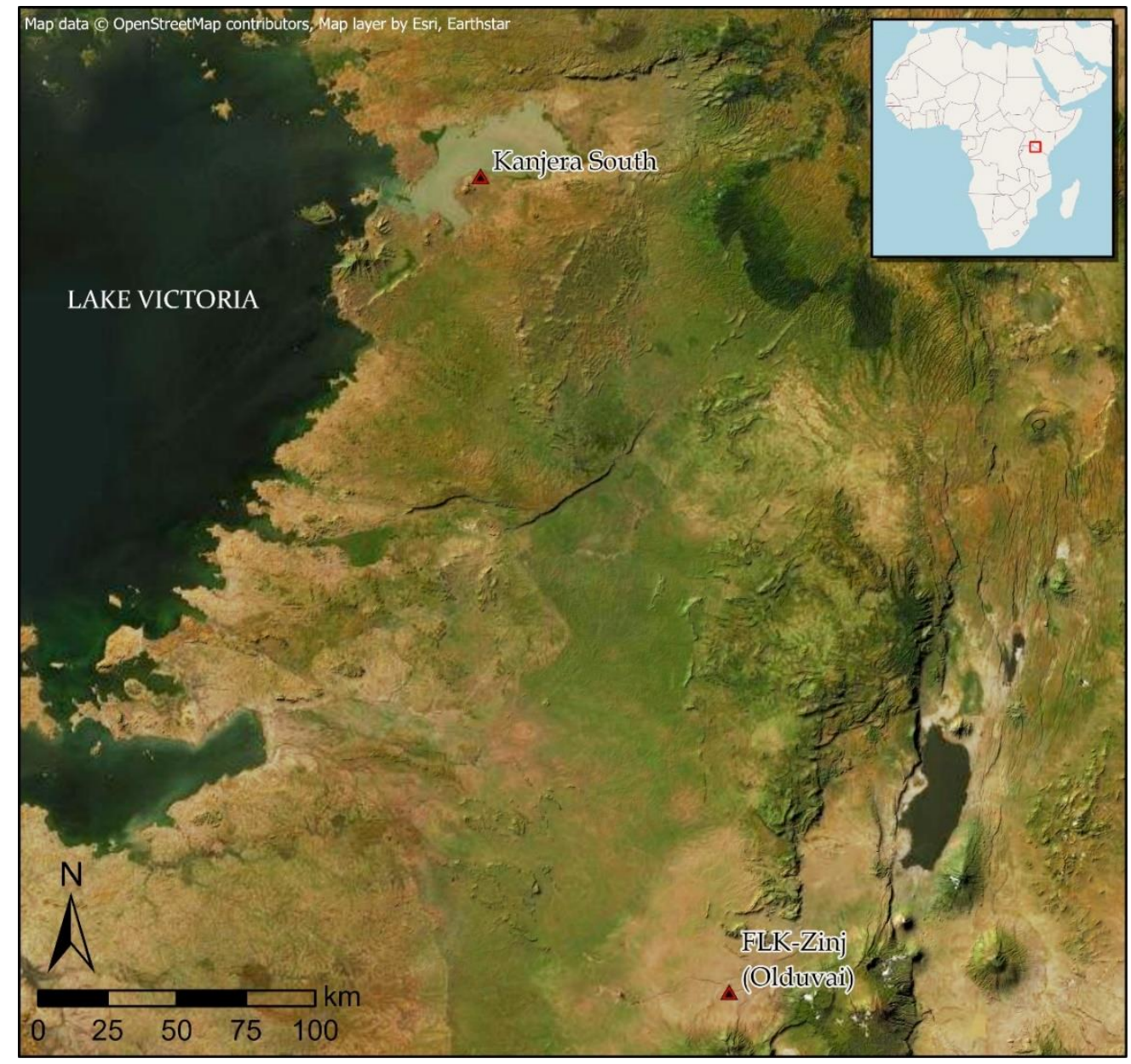

432 Figure 1. Map depicting the location of FLK-Zinj and Kanjera South, the two main Oldowan case433 studies discussed in the paper. 
In terms of the lithic assemblages, Kanjera South frequently evidences bifacial centripetal

435 schemes, including on relatively large flakes, while $28 \%$ of the raw materials exploited were

436 selectively transported $>10 \mathrm{~km}$ from conglomerates in the neighboring Awach drainage basin

437 (Braun et al., 2008; Braun et al., 2009a; Braun et al., 2009b). This may also be reflected in the

438 underrepresentation of cores in relation to flakes at the site, suggesting cores were transported into

439 the site for flake production, and then removed from the site for future use (Plummer and Bishop,

440 2016). Unidirectional unifacial methods were often restricted to local fenetized Nyanzian rhyolites

441 or dacites and Homa limestone or phonolite of poorer quality (Braun et al., 2009a; Reeves et al.,

442 2021), with transported materials being more heavily worked, and were selected according to the

443 durability of their cutting edge over flaking predictability (Braun et al., 2009a; Braun et al., 2009b;

444 Reeves et al., 2021). Flakes from these non-local raw materials also occasionally display secondary

445 retouch, something that is extremely rare for the Oldowan (Plummer and Bishop, 2016; Gallotti,

446 2018). These patterns of relatively long-distance transport and elongated reduction sequences are

447 suggestive of a considerable planning of activity across the landscape, potentially related to

448 predictability of resource exploitation.

449 In contrast, the FLK-Zinj lithic assemblage is characterized by unidirectional and unifacial

450 reduction on local quartzite raw materials, resulting in a greater impression of expediency than

451 Kanjera South (Leakey, 1971; de la Torre and Mora, 2005; Braun et al., 2009a; Gallotti, 2018).

452 Immediately local lava (particularly basalt) cobbles are abundant in Leakey's (1971) unmodified

453 'manuport' assemblage, but represent a much smaller proportion of exploited cores, suggesting a

454 preference for the quartzite material (de la Torre and Mora, 2005). This pattern suggests selection

455 for cutting ability over durability (Key et al., 2020). Retouched flakes are also very rare, despite

456 flakes and flake fragments representing the focus of the assemblage (Leakey, 1971; de la Torre 
457 and Mora, 2005; Gallotti, 2018). Taken together, the raw material transport distances at FLK-Zinj,

458 similar to many other Olduvai Bed I sites (Gallotti, 2018), hint at a directional movement into the

459 Olduvai paleolandscape via an appropriate raw material source (i.e. Naibor Soit).

460 The taphonomic evidence from the faunal assemblages, which we discuss in more detail

461 below, suggests that hominins had primary access to carcasses at both Kanjera South and FLK-

462 Zinj (e.g., Bunn, 1981; Domínguez-Rodrigo, 2009; Bunn and Pickering, 2010; Ferraro et al., 2013;

463 Parkinson, 2013; but see Pante et al., 2012). However, we would argue that paleoecological and

464 taphonomic data illustrate differences in the nature and seasonality of resource procurement

465 strategies between Kanjera South and FLK-Zinj.

467 4.1. Kanjera South

468 The site of Kanjera South (western Kenya) is centrally located within the northern margins

469 of the alluvial fans that cover the carbonatite geology of the Homa Peninsula, by the shore of

470 Winam Gulf, Lake Victoria (Behrensmeyer et al., 1995; Plummer et al., 1999; Plummer and

471 Bishop, 2016). The presence of lithic and faunal remains in the colluvial and alluvial silts and

472 sands of beds KS1-3 has been dated to 2.30-1.92 Ma through magneto- and bio-stratigraphy

473 (Ditchfield et al., 2019). The gentle nature of the deposition and the high sedimentation rates at

474 the lake margin, as suggested by minimal bone weathering and absence of both fluvial rounding

475 and debris-flow accumulations, favored the good preservation of archeological remains (Ditchfield

476 et al., 2019). The primary context of the site is further reinforced by the existence of several artifact

477 refits and the diversity of skeletal parts with differing water transport potential (Plummer et al.,

478 2009; Parkinson, 2013). The recurrent sedimentation cycles have afforded researchers an

479 opportunity to explore the nature of Oldowan hominin behavior through the time-lapse represented 
480 in the KS1-3 beds, since humans were the primary biotic agent responsible for the accumulation

481 of archeological materials (Ferraro et al., 2013). Another interesting paleoecological component

482 of the Kanjera ecosystem is the predominance of open $\mathrm{C}_{4}$ grassland habitats, alongside some

483 indications of woodland/grassland ecotones and a permanent watercourse, as inferred from the

$484 \delta^{13} \mathrm{C}$ values of soil carbonates and herbivore enamel (Plummer et al., 2009). This existence of

485 nearby watercourses is reinforced by the presence of water-dependent taxa, such as hippotamids,

486 crocodilians, and reduncine bovids, although they are relatively rare in the sequence (Oliver et al.,

487 2019). The stability of resource exploitation strategies throughout the three archeological levels at

488 Kanjera South attests to the consistently productive nature of the landscape and repeated seasonal

489 attraction of the site over hundreds or even thousands of years (Ferraro et al., 2013; Lemorini et

490 al., 2014; Ditchfield et al., 2019).

491 In terms of zooarcheological data, the Kanjera South assemblage shows an even

492 representation of skeletal part profiles for small bovids (e.g., Antidorcas sp., Gazella granti), which

493 indicates procurement and processing of whole carcasses. In relation to the mortality profiles,

494 dental eruption and epiphyseal fusion rates suggest that a high proportion (50\%) of both size 1-2

495 and size 3 bovids were young or subadult at the time of death (Parkinson, 2013; Plummer and

496 Bishop, 2016; Oliver et al., 2019; Table 3). The anatomical distribution of bone surface

497 modifications indicates that hominins had early access to the small prey size carcasses (Parkinson,

498 2013). The presence of cut-marks on small bovid remains, such as a metatarsal (KJS 7472) or the

499 proximal epiphysis of a femur (KJS 2565), is associated with limb disarticulation (Ferraro et al.,

500 2013), with the restricted intensity and frequency of carnivore damage indicating an only

501 occasional incidence of secondary scavenging (Parkinson 2013; Plummer and Bishop 2016). This

502 aligns well with the conclusions of Oliver et al. (2019) that the accumulation of size 1-2 bovids in 
503 the Kanjera South assemblage results from a hominin strategy of hunting vulnerable juvenile

504 individuals, which granted them complete and early primary access.

505

\begin{tabular}{cccccc}
\hline Bovid category & Young juveniles & Subadult juveniles & Prime adults & Old adult & Total MNI \\
\hline Small bovids (sizes 1-2) & $7(31.8 \%)$ & $4(18.2 \%)$ & $8(36.4 \%)$ & $3(13.6 \%)$ & 22 \\
Larger bovids (sizes 3a/3b) & $8(20.0 \%)$ & $12(30.0 \%)$ & $18(45.0 \%)$ & $2(5.0 \%)$ & 40 \\
\hline
\end{tabular}

506 Abbreviations: MNI = minimum number of individuals.

507 Table 3: Bovid mortality profiles from Kanjera South, in terms of MNI (\%). Data derived from 508 Oliver et al. (2019: Table 2).

509 We can better understand the seasonal relevance of the Kanjera South mortality profiles by 510 using analogues derived from extant bovid ecology (Foley, 1983). The temporality and 511 synchronicity of African bovid births are considerably variable, based on the timing of food supply 512 growth (in relation to both protein peak and overall biomass), the length of time food is available, 513 and anti-predator behavior exhibited (Jarman, 1974; Rutberg, 1987; Ims, 1990; Sinclair et al., 514 2000; Kingdon, 2015). According to Sinclair et al. (2000), most small bovid species living in small 515 groups with non-precocial calves give birth during the wet season, although they do not exhibit a 516 high degree of birth synchronicity. Gazella spp. for example, tend to produce their young early in 517 the wet season, ahead of the high protein peak (Sinclair et al., 2000). In contrast, bovids living in 518 larger herds with precocial young tend to have more tightly synchronized birth periods (Sinclair et 519 al., 2000). Of particular relevance to the Kanjera South zooarcheological assemblage —where 520 Alcelaphini (3a) play an important role (Ferraro et al. 2013; Oliver et al. 2019) — topi (Damaliscus 521 lunatus) births also tend to peak around the onset of the wet season (Sinclair et al., 2000). As such, 522 the number of juveniles from a range of bovid species is likely to peak during the wet season 
523 (Pereira et al., 2014; Kingdon, 2015). This abundance makes them a paramount seasonal resource

524 that is most frequently exploited by omnivorous, rather than obligate, carnivores (Pereira et al., 525 2014).

526 Small African antelope species, such as Gazella spp. and dik-dik (Madoqua spp.), follow a 527 'hider' strategy (cf., Jarman, 1974), through which mothers conceal their calves rather efficiently 528 in the tall grass, out of sight from stalking cheetahs and other predators (Murdock et al., 1983; 529 Ralls et al., 1986; FitzGibbon, 1993). However, hominins would have been able to overcome these 530 anti-predator strategies and turn them into a predictable source of compensatory hunting 531 opportunities by investing time into learning how to track the maternal vocalizations of gazelles 532 prior to their daily feeding instances (Lent, 1974). This knowledge would, in turn, reveal the 533 location of vulnerable nursing juveniles to the hominin groups that were actively monitoring the 534 behavior of these species (cf., Oliver et al., 2019). Gaining access to small bovid calves could have 535 provided hominins with a mechanism to attract and capture adult females as well: recent 536 observations of Hadza hunting practices documented how a hunter deliberately distressed a 537 recently-captured kudu calf so it would call its mother for help (Corey, 2021). On the basis of prey 538 ethology, we argue that the active human hunting of juvenile bovids in the grassland environment 539 of Kanjera South evidences hominin presence during at least the early-mid wet season at the site.

540 Such a seasonal pattern would be consistent with observations of wet season Hadza hunting 541 patterns (Hawkes and O'Connell, pers. comm.), the relatively low levels of carnivore competition 542 documented at the site (Parkinson, 2013), and the paleoecological relevance attributed to 543 seasonally moist soils and ephemeral streams (Ditchfield et al., 2019). At the same time, more 544 analytical data is needed to confirm the season of death of ungulates acquired at the site, with 545 research into bovid tooth microwear patterns underway (T. Plummer and J. Oliver, pers. comm.). 
546 If a pattern of broadly wet season ecology holds for the wider occupation of Kanjera South, we

547 would predict hominins to be preferentially targeting fat-rich animal products when available,

548 while also focusing on abundant and accessible plant resources, such as USOs.

549 Such a preference for fatty resources may be hinted at in the exploitation of larger ungulates

550 in the Kanjera South faunal assemblage. In comparison to the smaller bovid size classes, the

551 mortality profiles for size 3 bovids at Kanjera South are still biased towards young and sub-adult

552 individuals (see Table 3 above), although they show an increase in the proportion of prime-aged

553 individuals with regards to the minimum number of individuals (MNI; Oliver et al., 2019). This

554 pattern has been suggested to be representative of a combined strategy of compensatory hunting

555 of younger individuals as well as the scavenging of carcasses from other carnivore kills (Oliver et

556 al., 2019). The zooarcheological evidence for the medium-large bovid assemblage at Kanjera

557 exhibits an uneven skeletal part representation that reflects a weight-minimizing carcass transport

558 strategy (Ferraro et al., 2013). Selective body part transport should reflect an attempt to maximise

559 net nutritional returns, although the overrepresentation of bovid crania and mandibles at Kanjera

560 South, differs from usual patterns documented among the Hadza and other hunter-gatherers

561 (Binford, 1978; Bunn et al., 1988; O’Connell et al., 1988a; O’Connell et al., 1990; Metcalfe and

562 Barlow, 1992; O’Connell et al., 1992; Schoville and Otárola-Castillo 2014). We speculate this

563 deviation may be a consequence of a) a potentially greater reliance on passive scavenging when

564 acquiring cranial remains, resulting in reduced access to the yields of other body parts, and/or b)

565 that ethnographic observations of carcass acquisition and transport often take place in the dry

566 season, which may not account for seasonal fluctuations in the nutritional quality of different body

567 parts. In this context, marked asymmetries in skeletal part profiles of prime-aged individuals in the

568 Kanjera medium-large bovid assemblage-potentially derived from overlapping and very 
569 different acquisition and butchery events (cf., Lupo, 2001) - may also skew the overall MNI

570 patterns away from juvenile specimens, which still represent $50 \%$ of individuals in this bovid size

571 class (Table 3).

572 The taphonomic signatures of post-cranial remains of medium-large bovids highlight the

573 presence of cut-marks on ribs and limb bones, occurring alongside a limited number of carnivore

574 tooth marks (Ferraro et al., 2013; Parkinson, 2013). This taphonomic pattern indicates that

575 hominins had access to viscera and highly-prized cuts of meat. These body parts are usually

576 consumed quickly by lions and other carnivores following a kill (O'Connell et al., 1988b;

577 Domínguez-Rodrigo, 1999). This pattern would suggest that the role of primary carcass acquisition

578 methods in the formation of the post-cranial faunal assemblage was quite considerable, perhaps

579 resembling more closely the pattern of hunting young and subadult individuals suggested by Oliver

580 et al. (2019) for the smaller bovid size class. A recent comparative multivariate discriminant

581 analysis of Oldowan mortality patterns further indicates that Kanjera South hominins had early

582 access to medium-sized bovids (Cobo-Sánchez, 2020).

583 With regards to post-cranial within-bone nutrients, Parkinson (2013) notes that percussion

584 marks in the entire bovid assemblage are predominantly found on tibiae (c.40\%) - the highest-

585 ranked bone for marrow extraction in terms of calorific output (Blumenschine and Madrigal,

586 1993) - while their overall count across all main long limb bones is low $(n=15 / 6 \%$, consistent

587 with the 6-9\% values on midshaft fragments reported by Ferraro et al., 2013). This pattern of low

588 percussion mark counts despite high bone fragmentation might have been caused by a breakage

589 pattern in which hominins broke the bones against an anvil (Oliver, 1992; Parkinson, 2013).

590 Nonetheless, the low emphasis on within-bone nutrients of limb bones at the site may have also

591 been related to the seasonal temporality of marrow fat depletion (Sinclair, 1975; Speth, 1987; 
592 Speth et al., 1991). In this context, we also note that the proportion of midshafts with percussion 593 marking increases with bovid size class in the KJS-1 and KJS-2 units (Parkinson, 2013). This 594 pattern is consistent with observations that larger animals preserve increased quantities of fat for 595 longer during periods of nutritional depletion (Cordain et al., 2000). The overabundance of isolated cranial and mandibular remains seems to suggest a 597 preferential transport of these elements to the site, with the presence of clear percussion striae 598 confirming that hominins targeted the consumption of their contents (Ferraro et al., 2013). The 599 excess cranial elements in proportion to post-cranial MNI counts may imply a different 600 procurement strategy, perhaps involving some extent of scavenging on skeletal parts left 601 untouched by primary predators (Ferraro et al., 2013; Oliver et al., 2019). Alternatively, their 602 presence may reflect the selective exploitation of natural deaths derived from late dry season 603 carrion pulses, and/or the hunting of these animals primarily to target their crania and mandibles 604 before an early abandonment of the rest of the fat-depleted carcass. Regardless, the procurement 605 and exploitation of cranial remains would be consistent with an attempt to maximize consumption 606 of fatty and energy-dense animal resources, such as brain matter and the mandibular nerve and/or 607 marrow (Blumenschine, 1987; Speth, 1987; Cordain et al., 2000; Ferraro et al., 2013). Since fatty 608 brain tissue contains one of the lowest protein percentages of any animal tissue (Jayathilakan et 609 al., 2012), their consumption would have assisted Kanjera South hominins in avoiding the "protein 610 ceiling'. The behavioral patterns inferred for the hominins at Kanjera South can be integrated into 611 a coherent animal exploitation strategy using insights from observations of modern hunter612 gatherers. In their ethnoarcheological study of a Kua rainy season camp (//oabe I)—occupied by 61314 people for 7 nights - Bartram et al. (1991) noted that all nine ungulates procured were juvenile 614 or neonatal, easily obtained once their hiding places were located, and the juvenile carcasses were 
615 brought back whole to the camp. Furthermore, the Kua processed the skulls at the site to extract

616 the brains and cranial pulps (Bartram et al., 1991). The acquisition of younger complete carcasses,

617 alongside the larger bovid skulls, may have provided the Kanjera hominins with a similar

618 opportunity to intensively exploit fat resources from younger carcasses and to obtain fat-rich

619 material from both the complete juveniles and isolated skulls, including the fatty cranial matter.

620 As well as the evidence for the targeting of fatty animal resources, there is evidence for the

621 exploitation of non-animal resources at Kanjera South. Indeed, use-wear analysis of the lithics

622 reveals that, while around a third of tools were associated with butchery, the majority show signs

623 of use related to the processing of medium-hard plant material, including wood and USOs

624 (Lemorini et al., 2014; Lemorini et al., 2019). The processing and consumption of USOs at Kanjera

625 South may match our predictions that they were a seasonally-relevant resource for hominins during

626 times of reduced preferred food availability, such as when terrestrial ungulates are dispersed and/or

627 fat-depleted (e.g., Speth, 1987; Laden and Wrangham, 2005; Hernandez-Aguilar et al., 2007;

628 Marlowe and Berbesque, 2009; Wrangham et al., 2009; Sato et al., 2012).

629 The use-wear data also highlight a preferential use of non-local quartzites and rhyolites in

630 plant processing, with the four analyzed retouched flakes of these materials showing evidence of

631 cutting and scraping activities on medium-hard surfaces. At least three of these flakes were used

632 on wood or hard herbaceous plants (Lemorini et al., 2014; Lemorini et al., 2019). This use-wear

633 evidence for wood processing may be related to the production of organic tools, potentially

634 including digging sticks for the extraction of USOs and hunting spears (Lemorini et al., 2014;

635 Lemorini et al., 2019). Chimpanzees are known to use a diverse set of manufactured wooden tools,

636 predominantly during the (early) wet season, for these purposes (Hernandez-Aguilar et al., 2007;

637 Pruetz and Bertolani, 2007; Wynn et al., 2011), as well as for colonial invertebrate fishing 
638 (McGrew et al., 1979; Goodall, 1986; Stewart and Piel, 2014; Hicks et al., 2019; Pascual-Garrido

639 and Almeida-Warren, 2021). The Hadza also use wooden digging sticks to access USOs (Vincent,

640 1985). While preservation of wood is rare in the archeological record, recent finds from

641 Gantangqing, China, indicate that hominins in subtropical environments were (seasonally)

642 manufacturing such pointed implements and using them to obtain USOs, at least by the Late

643 Middle Pleistocene (Gao et al., 2021). Investment in the production of wooden implements at

644 Kanjera South is consistent with an attempt to minimize acquisition and processing costs of a

645 desirable and predictable resource to maximize return yields (Ferraro, 2007; Clark and Linares-

646 Matás, 2020). Although similar use-wear analyses at other sites are required for comparative

647 purposes, we suggest that plant resource exploitation at this site may have played a greater role in

648 governing the intensive exploitation of raw materials and the movement of lithics throughout the

649 landscape than is conventionally discussed in the Oldowan literature.

$651 \quad 4.2$ FLK-Zinj

652 Frida Leakey Korongo-Zinjanthropus (FLK-Zinj) is a site located in Olduvai Gorge,

653 Tanzania, situated within a very tight geographic cluster with most of Mary Leakey's (1971) sites

654 in the Upper Member of Bed I. This pattern may be coincidental, or a reflection of specific features

655 of the Olduvai landscape which were particularly attractive for the subsistence activities of

656 hominins and carnivores (Domínguez-Rodrigo et al., 2010). Indeed, paleogeographic

657 reconstruction of the Olduvai landscape emphasizes the presence of a saline-alkaline lake and a

658 perennial freshwater spring, the latter of which lies very close to the known cluster of Bed I sites

659 (Ashley et al., 2010; Domínguez-Rodrigo et al., 2010; Blumenschine et al., 2012). The presence

660 of the perennial spring amidst lower lake levels fostered the development of a biodiverse 
661 freshwater wetland at Olduvai (Ashley et al., 2009; Ashley et al., 2010; Domínguez-Rodrigo et al.,

662 2010). This ecological setting would have been extremely attractive to dehydrated herbivores

663 throughout the dry season - and by extension to hominins and carnivores, due to both their needs

664 for drinking water and the opportunities for the active procurement of prey (Speth and Davis, 1976;

665 Domínguez-Rodrigo et al., 2010; Hawkes, 2016; Domínguez-Rodrigo et al., 2019a).

666 On the basis of paleoecological reconstructions, the location of FLK-Zinj, on a topographical

667 elevation by the edge of a lake floodplain, may have enjoyed a mosaic woodland vegetation pattern

668 which could have offered hominins some degree of protection from carnivores (Ashley et al., 2010;

669 Blumenschine et al., 2012; Uribelarrea et al., 2014; Arráiz et al., 2017). The skeletal part profiles

670 of the site show a diverse taxonomic composition and near-complete representation of skeletal

671 parts, although with an underrepresentation of the axial skeleton. Bunn (1986) suggests the high

672 proportion of cranial remains and long bones suggests selective transport of high-ranking body

673 parts into the site, whereas Blumenschine (1991) suggested that the pattern could reflect hominin

674 transport of skeletal remains from scavenged carnivore kills. Other authors have suggested that the

675 underrepresentation of axial elements and the limited evidence for disarticulation at FLK-Zinj

676 derives from processes resulting in density-mediated differential preservation, such as secondary

677 carnivore ravaging (Marean et al., 1992). From this perspective, near-complete carcasses would

678 have been originally transported to the site from procurement spots located relatively short

679 distances away (O’Connell et al., 2002; Faith et al., 2009; Domínguez-Rodrigo et al., 2010). Some

680 degree of carcass transport towards a more sheltered spot mitigated carnivore competition at FLK-

681 Zinj, evidenced by the presence of tooth marks on bovids and even on at least one hominin

682 individual, bearing crocodile and leopard tooth marks (Domínguez-Rodrigo et al., 2010;

683 Blumenschine et al., 2012; Njau and Blumenschine, 2012; Egeland, 2014; Aramendi et al., 2017). 
While most Bed I lithic assemblages are associated with fauna of initial carnivore origin 685 (Domínguez-Rodrigo et al., 2007), the functional association of lithics and faunal remains at FLK686 Zinj is reinforced by taphonomic evidence suggesting hominins had primary access to the 687 carcasses (e.g., Bunn, 1981; Domínguez-Rodrigo, 1997; Domínguez-Rodrigo and Barba, 2006; 688 Parkinson, 2018). These factors indicate that carcass procurement and processing were co689 occurring spatially at FLK-Zinj (Domínguez-Rodrigo and Cobo-Sánchez, 2017). Nonetheless, 690 there is debate as to whether the dense concentrations of lithic artifacts and exploited faunal 691 remains during the accumulation of the sedimentary unit at this focal point for hominin activity 692 reflects prolonged occupations (e.g., Ashley et al., 2010), or a series of brief but recurrent visits 693 limited to feeding (e.g., Blumenschine et al., 2012) within an extremely productive environment. 694 The taxonomic composition of the FLK-Zinj anthropogenic faunal assemblage mostly 695 reflects local, non-migratory species, such as Kobus, Antidorcas, and Parmularius (Domínguez696 Rodrigo et al., 2019b). Springbok (Antidorcas sp.) dominates the small-medium (size 1-2) 697 assemblage, while waterbuck (Kobus sp.) is the most common amongst the size 3 bovids (Bunn 698 and Pickering, 2010). Nowadays, migratory taxa (i.e., wildebeest [Connochaetes gnou]) are 699 present in the Olduvai landscape mostly during the short wet season (Domínguez-Rodrigo et al., 700 2019b), although resident subpopulations may remain in the region year-round. Thus, if these 701 actualistic patterns are relevant for understanding Early Pleistocene paleoecological patterns, the 702 underrepresentation of migratory taxa would primarily suggest a dry season occupation 703 (Domínguez-Rodrigo et al., 2019a). Models of calorific return from the marrow of different long 704 bones at FLK-Zinj suggest that the exploited animals had suffered only very limited fat depletion 705 (Blumenschine and Madrigal, 1993). This observation would also be consistent with a broadly dry 706 season occupation. 
While sample sizes are currently small, meso-wear and micro-wear patterns on ungulate

708 teeth from the site suggest that the anthropogenic components of the FLK-Zinj assemblage likely

709 formed during a single seasonal occupation, in contrast to the carnivore-accumulated Olduvai

710 assemblage of FLK-N, which reflects more prolonged periods of carcass acquisition throughout

711 the year (Domínguez-Rodrigo et al., 2019b). The tooth wear pattern could also represent repeated

712 occupations in the same season over time, but the limited subaerial weathering documented on

713 bone surfaces is more suggestive of relatively rapid sedimentary deposition (Domínguez-Rodrigo

714 et al., 2007; Domínguez-Rodrigo et al., 2019b). Waterbuck teeth, the best-represented size 3 bovid

715 at the site, exhibit a microwear pattern consistent with a mixed feeding diet (Domínguez-Rodrigo

716 et al., 2019b). This pattern would better fit the dry season dietary preferences of waterbuck, since

717 reduncines tend to follow a predominantly grazer regime during the wet season (Child and Richter,

718 1969; Herbert, 1972; Spinage, 1982; Gagnon and Chew, 2000; Kassa et al., 2007). Assuming FLK-

719 Zinj was indeed primarily occupied during the dry season, we suggest that procurement of

720 terrestrial animal resources, including meat, should represent an important part of the dietary

721 strategy at the site.

722 The mortality profiles of size 1 and 2 bovids at FLK-Zinj are old-dominated (5/7, 71\%; Bunn

723 and Pickering 2010; Table 4). This pattern differs from leopard ambush hunting strategies, mostly

724 focused on prime adults, meaning it is unlikely that size 1 and 2 bovids were confrontationally

725 scavenged (Bunn and Pickering, 2010). Furthermore, primary hominin access is inferred

726 taphonomically on the basis of the distribution of cut-marks on the high meat-yielding proximal

727 and intermediate limb bones, complemented by the presence of percussion marks for marrow

728 extraction, particularly on the tibiae (Parkinson, 2018). Early access is also supported by the nature

729 of tooth mark density distribution on the tibiae and other hindlimb bones, which closely resembles 
730 an experimental model in which the carnivore access follows hominin hammerstone use

731 (Parkinson, 2018). Taken together, we would argue that the age profile seen amongst the small-

732 medium bovids at FLK-Zinj is most consistent with compensatory hunting of vulnerable

733 individuals.

\begin{tabular}{|c|c|c|c|c|c|c|}
\hline Bovid category & $\begin{array}{c}\text { Young } \\
\text { juveniles }\end{array}$ & $\begin{array}{l}\text { Subadult } \\
\text { juveniles }\end{array}$ & $\begin{array}{c}\text { Early prime } \\
\text { adults }\end{array}$ & $\begin{array}{l}\text { Late prime } \\
\text { adults }\end{array}$ & Old adults & $\begin{array}{l}\text { Total } \\
\text { MNI }\end{array}$ \\
\hline Smaller bovids (sizes $1-2$ ) & $0(0.0 \%)$ & $1(14.3 \%)$ & $1(14.3 \%)$ & $0(0.0 \%)$ & $5(71.4 \%)$ & 7 \\
\hline Larger bovids (sizes $3 \mathrm{a} / 3 \mathrm{~b} / 4$ ) & $2(10.0 \%)$ & $4(20.0 \%)$ & $8(40.0 \%)$ & $4(20.0 \%)$ & $2(10.0 \%)$ & 20 \\
\hline Waterbuck (Kobus sigmoidalis) & $2(22.2 \%)$ & $0(0.0 \%)$ & $3(33.3 \%)$ & $4(44.4 \%)$ & $0(0.0 \%)$ & 9 \\
\hline
\end{tabular}

Abbreviations: $\mathrm{MNI}=$ minimum number of individuals.

735 Table 4: Bovid mortality profiles from FLK-Zinj, in terms of MNI (\%). Data derived from Bunn 736 and Pickering (2010: Table 1).

737 Large bovid procurement strategies at FLK Zinj have been variously interpreted as evidence

738 of selective ambush hunting (e.g., Bunn and Pickering, 2010; Domínguez-Rodrigo and Pickering,

739 2017), non-selective (living structure), ambush hunting resembling Hadza and Kua practices

740 (Bunn and Gurtov, 2014), passive scavenging of felid-exploited carcasses (e.g., Blumenschine et

741 al., 2012; Pante et al., 2015), confrontational scavenging of carnivore kills (e.g., Bunn, 2001; Bunn,

742 2007; O'Connell et al., 2002), or exploitation of carrion pulses (Capaldo and Peters, 1995; Lim,

743 2008). These strategies have also been evaluated with taphonomic evidence for hominin

744 engagement with the carcasses, as well as the mortality profiles of the large bovid remains. With

745 regards to the latter, the age profiles reported by Bunn and Pickering (2010) show a predominance

746 of prime-aged individuals $(12 / 20 ; 60 \%)$, with the proportion increasing to $77.8 \%$ (7/9) for

747 waterbuck (Kobus sigmoidalis, size 3b). 
Carrion pulses due to natural mortality are common towards the end of the dry season, when

749 large herbivores are most likely to succumb to severe physiological stress (Sinclair et al., 2003;

750 Pereira et al., 2014). However, they are unlikely to have provided extensive amounts of edible

751 meat for hominins at FLK-Zinj, since these carcasses would be severely fat-depleted and thus not

752 metabolically profitable (Speth, 1987; Blumenschine, 1987). Moreover, the mortality profiles at

753 the site, especially the underrepresentation of old-age individuals, are substantially different to

754 modern mass death events (Bunn and Gurtov, 2014). This is supported by systematic sampling

755 carried out by The Olduvai Palaeoanthropology and Palaeoecology Project (TOPPP), which did

756 not document large quantities of carcasses near the perennial spring at the time of FLK-Zinj

757 occupation. This suggests that the hominin presence in the landscape was not coeval with any

758 sizable carrion pulse (Domínguez-Rodrigo et al., 2010).

759 The proposal of a marginal and passive interaction with exploited and abandoned carnivore

760 kills is undermined by evidence for recurrent early hominin access to the flesh of these

761 medium/large animals (e.g., Domínguez-Rodrigo et al., 2007; Parkinson, 2013). Both femora and

762 radio-ulnae show dense clusters of cut-marks in 'hot zones' (cf., Domínguez-Rodrigo, 1999),

763 demonstrating that hominins had primary access to fleshed carcasses (Oliver, 1994; Parkinson,

764 2018). Confrontational scavenging has been proposed as one way of reconciling evidence for

765 primary access without implying hominin hunting, since carnivore kills were a recurrent feature

766 of the Olduvai Bed I paleolandscape (Bunn and Kroll, 1986; Bunn, 2001; O’Connell et al., 2002)

767 and carnivore predation is a major source of mortality for medium-sized ungulates in the Serengeti

768 (Sinclair et al., 2003). These suggestions are, however, also difficult to reconcile with the cut-mark

769 distribution data discussed above, since the same elements of size 3 bovids with abundant cut-

770 marks at FLK-Zinj tend to be defleshed quickly by lions (O’Connell et al., 1988b; Domínguez- 
771 Rodrigo, 1999; Bunn and Pickering, 2010; Gidna et al., 2014). Furthermore, the mortality profiles

772 of lion kills are significantly different to that seen at FLK-Zinj, and the penecontemporaneous site

773 of DS, as the former tend to include substantially fewer prime adults (Bunn and Pickering, 2010;

774 Bunn and Gurtov, 2014; Cobo-Sánchez, 2020). Lastly, studies on the behavioral ecology of

775 carnivore predation have shown that extant lions tend to preferentially target larger prey sizes when

776 they are available, especially buffalo (size 4), across a range of ecosystems (Funston and Mills,

777 2006; Davidson et al., 2013; Dublin and Ogutu, 2015). This contrasts with the predominance of

778 size 1-3b bovids in anthropogenic Olduvai Bed I assemblages (Bunn and Pickering, 2010; Cobo-

779 Sánchez, 2020), further emphasizing that large felids were unlikely to have been the main agent

780 of accumulation at FLK-Zinj.

781 At FLK-Zinj, there is a single high-density cluster of faunal remains (Leakey, 1971). While

782 bone refuse in modern hunter-gatherer campsites tends to display a multi-cluster distribution that

783 differs from the FLK-Zinj pattern (Domínguez-Rodrigo and Cobo-Sánchez, 2017), the high

784 density of remains at the site mirrors the abundance of bone leftovers noted for dry season Kua

785 camps in the Kalahari (Bartram et al., 1991). While ca. 23\% of the analyzed assemblage exhibits

786 tooth-marks (Domínguez-Rodrigo et al., 2007; Parkinson, 2018), their distribution is not clustered

787 on primary-access areas, and thus they do not challenge the predominantly anthropogenic origin

788 of the assemblage (Parkinson, 2018). Instead, on the basis of the morphometry of tooth marks on

789 cancellous bone and the deletion of epiphyses, ribs, and pelvis fragments, it appears that hyenids

790 subsequently ravaged the FLK-Zinj faunal assemblage, which would account for the high tooth

791 mark frequencies (Domínguez-Rodrigo and Barba, 2006; Parkinson, 2018). These secondary

792 scavengers were likely attracted to the high concentration of bone refuse, scattering some of the 
793 remains away from the main cluster in the process (cf., Camarós et al., 2013; Domínguez-Rodrigo 794 and Cobo-Sánchez, 2017).

795 In addition to the zooarcheological and taphonomic data, actualistic insights from bovid 796 ecology can help elucidate further the nature of hominin carcass acquisition at the site. Since Kobus 797 sigmoidalis is the most abundant size 3 bovid at FLK-Zinj (Bunn and Pickering, 2010), we center 798 our discussion around it. This extinct waterbuck species is similar in size and phenotype to the 799 extant Kobus ellipsiprymnus in East Africa, presumably occupying similar habitats (Spencer, 800 1997). The species is gregarious and non-migratory (Foley, 1983), living in groups of 6-30 801 individuals. Waterbuck stay near active water sources, particularly during the dry season, since 802 waterbuck do not tolerate dehydration well (Taylor et al., 1969; Foley, 1983; Estes, 2004).

803 Females and their offspring form nursery herds, whereas young males unite in bachelor 804 herds, roaming the landscape in pursuit of an opportunity to displace the prime territorial male, 805 which is most dominant at 6-9 years of age (Kingdon and Hoffman, 2013). However, territorial 806 competition between bachelor herds and dominant males often results from the decrease in food 807 availability associated with the dry season (Tomlinson, 1979; Tomlinson, 1981). These tensions 808 lead to increases in activity which, alongside the decrease in food intake, is known to result in a 809 substantial decline in body condition in impala and other antelope species during periods of 810 competition, such as the rut (Murray, 1982; Van Rooyen, 1993). Around the age of ten, the primacy

811 of territorial males is often irrevocably challenged and they are replaced. After losing their status 812 and territory, these late prime males recede to small and unprotected areas of the landscape, which 813 renders them more vulnerable to predators (Kingdon and Hoffman, 2013). These late prime 814 individuals, however, are not yet ontogenetically old, since waterbuck live around 18 years in the 815 wild. As such, dry season hunting strategies should have avoided the acquisition of territorial, 
816 prime-aged males, not only because they might have been more difficult to hunt, but also because

817 they would have experienced fat depletion much quicker than other age and sex groups, such as

818 late prime males and especially pregnant waterbuck females. Kidney fat indices for many species,

819 such as impala (Aepyceros melampus) and nyala (Tragelaphus angasii), tend to be higher in

820 pregnant than non-pregnant individuals (Spinage, 1984).

821 A detailed examination of the waterbuck adult sample at FLK-Zinj $(n=7)$ shows that there

822 is a complete absence of peak prime-aged males (Bunn and Pickering, 2010). The sexual

823 dimorphism of this species allows the identification of three smaller, early prime females and four

824 larger, late prime males, which Bunn and Pickering (2010) suggest could represent these older,

825 non-territorial individuals. Furthermore, on the basis of unworn upper and lower deciduous

826 premolars, at least two, likely three, fetal individuals are present in the assemblage, which suggests

827 that the early prime females were captured during late gestation (Bunn and Pickering, 2010).

828 During this stage, pregnant female ungulates are most vulnerable to predation (Molinari-Jobin et

829 al., 2004; Owen-Smith, 2008). Furthermore, adult waterbuck females are observed in open forested

830 environments much more often than expected when compared to territorial and bachelor males

831 (Wirtz and Kaiser, 1988), perhaps making their presence in the woodland surrounding FLK-Zinj

832 more likely. Therefore, while the adult waterbuck individuals were ontogenetically prime, the

833 overrepresentation of pregnant females and late prime males suggests that hominins at FLK-Zinj

834 were more successful when targeting nursery herds and lone individuals as they passed through

835 woodland on approach to the perennial spring. Increases in hunting success rates would have

836 ensured that more individuals within the group obtained access to meat-derived nutrients (Kaplan

837 and Hill, 1985; Speth, 1990; Tennie et al., 2009). 
As such, we argue that Oldowan hominins enjoyed higher success rates when engaging in

839 compensatory hunting strategies targeting seasonally-vulnerable prey demographics. The active

840 exploitation of fleshed carcasses during the dry season would have provided hominins with early

841 access to energy-dense resources, such as meat ( $\sim 15 \%$ of bone specimens at FLK-Zinj display cut-

842 marks; Parkinson, 2018) and within-bone nutrients, such as marrow (22-23\% exhibit percussion

843 marks; Domínguez-Rodrigo et al., 2007; Parkinson, 2018). The resulting composition of the

844 assemblage, biased towards individuals who would subsequently be more likely to succumb to

845 physiological stress later in the dry season, may also help explain the degree of overlap in mortality

846 profiles between FLK-Zinj and the mostly non-anthropogenic 'background' assemblages at other

847 Olduvai Bed I sites (Bunn and Pickering, 2010: Figure 3).

848 We also suggest that dry season hunting patterns may have played a role in the expedient

849 nature of the lithic toolkit at FLK-Zinj, suggested by the overall predominance of relatively simple

850 unidirectional and unifacial reduction schemes and the lack of retouch on flakes (de la Torre and

851 Mora, 2005; Gallotti, 2018). Our seasonality framework would suggest that the meat and within-

852 bone nutrients of terrestrial ungulates were important resources for hominins throughout most of

853 the dry season, as they are for the Hadza (Bunn et al., 1988; Hawkes et al., 1991; O'Connell et al.,

854 1992; Marlowe and Berbesque, 2009). Future use-wear analysis will help to test this at FLK-Zinj

855 (cf., Bello-Alonso et al., 2019). Nevertheless, successful carcass acquisition endeavors may have

856 been rather unpredictable at the daily scale (Hawkes, 2000), making it more difficult to time the

857 use of tools throughout the landscape. In this context, we note the finding of Binford (1979) that

858 the lithics produced by the Nunamiut for an immediate need were notably less complex than those

859 used in pre-planned activities. Moreover, Kua hunter-gatherer groups in the Kalahari tend to

860 consume carcasses almost immediately during the hot dry season, and transport them only across 
861 short distances, to minimize their exposure to heat and predators (Bartram et al., 1991). Therefore,

862 while short-distance movement of carcasses from acquisition spots to the woodland ecotone at

863 FLK-Zinj provided some relative safety, these hazards would have fostered an expedient toolkit

864 that could be produced quickly to extensively process carcasses in a minimized amount of time.

865 The butchery activities documented taphonomically at FLK-Zinj heavily emphasize filleting

866 rather than disarticulation (Parkinson, 2018), and slicing meat offers little resistance to lithics

867 (Bello-Alonso et al., 2019). As such, the task can be achieved as successfully with unretouched

868 than with retouched flakes (Jones, 1994), thus discouraging the additional investment required by

869 the latter. That lithics and faunal remains at FLK-Zinj are functionally associated is further

870 supported by their correlated spatial distributions (Domínguez-Rodrigo and Cobo-Sánchez, 2017).

871 Risk-buffering processes may also explain investment in directional quartzite transport into the

872 site from the Naibor Soit, rather than use of the local lava cobbles which predominate in Leakey's

873 (1971) unmodified manuports (de la Torre and Mora, 2005). Quartzite flakes display greater initial

874 edge sharpness despite their reduced durability, and thus its selection suggests a desire to maximize

875 efficiency in short-term tasks (Key et al., 2020). In this context it is interesting to note that such a

876 preference for quartzite over basalt flakes (and handaxes) is directly associated with butchery

877 practices at the Bed II sites of FLK-W and BK (Yravedra et al., 2017a; Yravedra et al., 2017b).

878 Hominins were thus likely to have been planning their repeated visits to the site following

879 acquisition of carcasses during the dry season (Domínguez-Rodrigo et al., 2010). This behavioral

880 scheduling would have provided an opportunity to minimize the costs of transporting quartzite

881 across the landscape during hunting forays by maintaining a raw material presence at a known

882 processing spot, and quickly producing usable flakes when carcasses were brought to the site (cf.,

883 Potts, 1984; Potts, 1991). 


\section{Discussion}

885 5.1. Seasonality and Oldowan behavioral flexibility at Kanjera South and FLK-Zinj

As outlined above, we argue that the available data from Kanjera South (Kenya) and FLK-

887 Zinj (Olduvai Gorge, Tanzania) evidence a pattern of seasonal variation in Oldowan subsistence

888 strategies, which underscores the behavioral flexibility of early Homo. The term 'behavioral

889 flexibility' has a long history of use in relation to animal learning and adaptation in the fields of

890 behavioral psychology and behavioral ecology (e.g., Dickinson, 1981; Kummer and Goodall,

891 1985; Tebbich et al., 2010; Navarrete et al., 2016; Audet and Lefebvre, 2017). The term is used

892 here simply to highlight the problem-solving skills of Oldowan hominins, for whom seasonal shifts

893 would have constantly re-structured acquisition priorities on the basis of resource quality and

894 availability.

895 Using the nature of resource acquisition and processing at FLK-Zinj and Kanjera South as a

896 lens to study these phenomena, we suggest that seasonality played a profound role in the

897 subsistence strategies of Oldowan hominins, mirroring observations made in extant nonhuman

898 primates and modern human hunter-gatherers. Regarding terrestrial animal consumption

899 specifically, compensatory hunting strategies targeting vulnerable prey demographics emerged at

900 both sites, but differ in ways consistent with predictable seasonal cycles. At Kanjera South, small

901 bovid hunting focused on the exploitation of young individuals (Ferraro et al., 2013), perhaps

902 through the location and pursuit of newborn calves in the longer grasses (Oliver et al., 2019). On

903 the basis of small savanna bovid ecology, we argue that such a hunting strategy is more likely to

904 have been undertaken during the wet season, since most births tend to take place around the onset

905 of the rains (Sinclair et al., 2000; Kingdon, 2015; Pobiner, 2020). As such, this strategy would not 
906 have been as readily available at FLK-Zinj during the dry season. Instead, these hominins

907 predominantly targeted the vulnerability of pregnant or older individuals.

908 Meanwhile, carcass processing at Kanjera South was generally less intensive than at FLK-

909 Zinj, both in terms of defleshing and limb bone marrow processing (Domínguez-Rodrigo et al.,

910 2007; Ferraro et al., 2013; Parkinson, 2013; Parkinson, 2018). Instead, hominins at Kanjera South

911 preferentially targeted the brains and/or cranial pulp of large bovid skulls as well as mandibular

912 nerve and marrow (Ferraro et al., 2013), resources that would have maintained a greater fat content

913 into the early wet season (Sinclair, 1975). In this context, we suggest that activities enabling access

914 to consistently fat-rich resources, such as evisceration and brain extraction, would have been

915 particularly important during these periods of ungulate depletion. In contrast, the utility of

916 defleshing and marrow extraction would have been much greater when bovid fat stores were more

917 substantial. We also speculate that disarticulation may have been more relevant throughout the wet

918 season as a whole, as ungulate dispersal and hominin movement through the landscape were

919 generally more extensive. Nonetheless, we note that ethnoarcheological assessments of differential

920 body part transport by animal condition (pregnant, juvenile, feeble) or season of acquisition are

921 limited by small sample sizes (Lupo, 2006), meriting further research.

922 As ungulate carcasses exhibit fat depletion from the very late dry season into the wet season

923 (Sinclair, 1975; McNaughton and Georgiadis, 1986), a contextual paleoecological assessment

924 (Table 5) can assist in discerning seasonality when taphonomic research indicates a degree of meat

925 and marrow avoidance (Speth, 1987; Blumenschine and Marean, 1993; Bunn and Ezzo, 1993). For

926 example, within the Lower Augitic Sandstone (LAS) unit of HWK-EE (Olduvai Gorge), Pante et

927 al. (2018) report a pattern of fat-depleted marrow and epiphyseal grease avoidance by both

928 carnivores and hominins, characterized by high epiphyseal to shaft fragment ratios (0.23; cf., 
929 Blumenschine and Marean, 1993) alongside low tooth mark (5.4\%) and percussion mark values

930 (7.8\%). The proportion of midshaft fragments with percussion marks closely mirrors the 6-9\%

931 values reported for Kanjera South and are well below those from FLK-Zinj (Ferraro et al., 2013;

932 Parkinson, 2018). This relatively limited engagement with within-bone nutrients occurs alongside

933 cut-marked hippopotamid remains, a considerable number of shed crocodile teeth (Pante et al.,

934 2018), and a notable concentration of fish remains suggesting a catastrophic mortality episode

935 (Bibi et al., 2018). This mortality profile is expected from modern observations of fish becoming

936 trapped in pools as the water recedes in the late dry season (Leakey, 1971; Stewart, 1994). Extant

937 crocodiles also tend to congregate within increasingly isolated pools of water towards the end of

938 the dry season (Njau, 2012), a time they are known to share them with hippopotami (Kofron,

939 1993). This suggests an occupation of LAS at HWK-EE that encompassed the very late dry season,

940 which would be consistent with the more general dry season indication given by bovid tooth micro-

941 and meso-wear data (Rivals et al., 2018).

942

Given the patterns of marrow and grease avoidance, it is perhaps surprising that pounding

943 and/or percussive tools at HWK-EE (found in greater number than at any other Olduvai Bed I-II

944 site) are most abundant within the LAS ( $n=283 ; 81.1 \%$; Arroyo and de la Torre, 2018). The

945 intensity of contact on the active areas of most of these tools suggest a direct percussive motion

946 and use in hard hammer lithic manufacture (Arroyo and de la Torre, 2016, 2018). Many

947 hammerstones with active edges (HAE), anvils, and subspheroids, however, have lower-intensity

948 wear patterns (Arroyo et al., 2018). Experimental tools used to open nuts, tenderize meat, extract

949 marrow from limb bones, and process tubers show low-intensity wear (de la Torre et al., 2013;

950 Sánchez-Yustos et al., 2015; Arroyo et al., 2016). In this regard, the limited evidence for percussive

951 breakage of bone shafts in this late dry season context (Pante et al., 2018) may suggest that these 
952 pounding tools may have targeted resources other than marrow. In particular, nuts and seeds can 953 represent an attractive seasonal source of unsaturated fats, often linked with the ripening (and 954 rotting) of fruits and grasses at seasonal transitions (Testart, 1982; Hitchcock et al., 1996; Eaton et 955 al., 1997; Lee 2013; Lombard and Kyriacou 2018). Procurement and consumption of nuts 956 throughout the dry season is amply documented among African hunter-gatherers in both tropical 957 rainforests and more open environments (Kitanishi 1994; Hitchcock et al., 1996; Sato et al., 2012;

958 Lee, 2013; Remis and Jost Robinson 2014; Gómez et al., 2016; Ingram et al., 2017). Nuts and 959 seeds may therefore have been possible resources requiring pounding that could compensate for 960 fat depletion in Oldowan food procurement strategies, particularly during the very late dry season.

961 Table 5: Summary of predictions discussed in the text for assessing seasonality of site use in the 962 Oldowan, derived from the comparison of Kanjera South and FLK-Zinj and incorporating insights 963 from other Early Pleistocene localities discussed in the text. Presence or absence of migratory taxa 964 may also be a relevant seasonal, landscape-specific paleoecological signature. Note that hominin 965 occupation at some Oldowan sites may span more than one season or a seasonal transition 966 (potentially including FwJj20), while natural site formation processes may also result in the 967 deposition of background material from successive seasons. With regards to assessments of 968 mortality profiles, skeletal part profiles, and spatial distribution of faunal remains, it is important 969 to consider the impact of secondary carnivore ravaging, post-depositional transport, and bone 970 preservation biases due to biogeochemical processes. Any of these factors would compromise the 971 integrity of the faunal assemblage, making inferences regarding the specific nature and intra972 annual timing of hominin activity more difficult. 


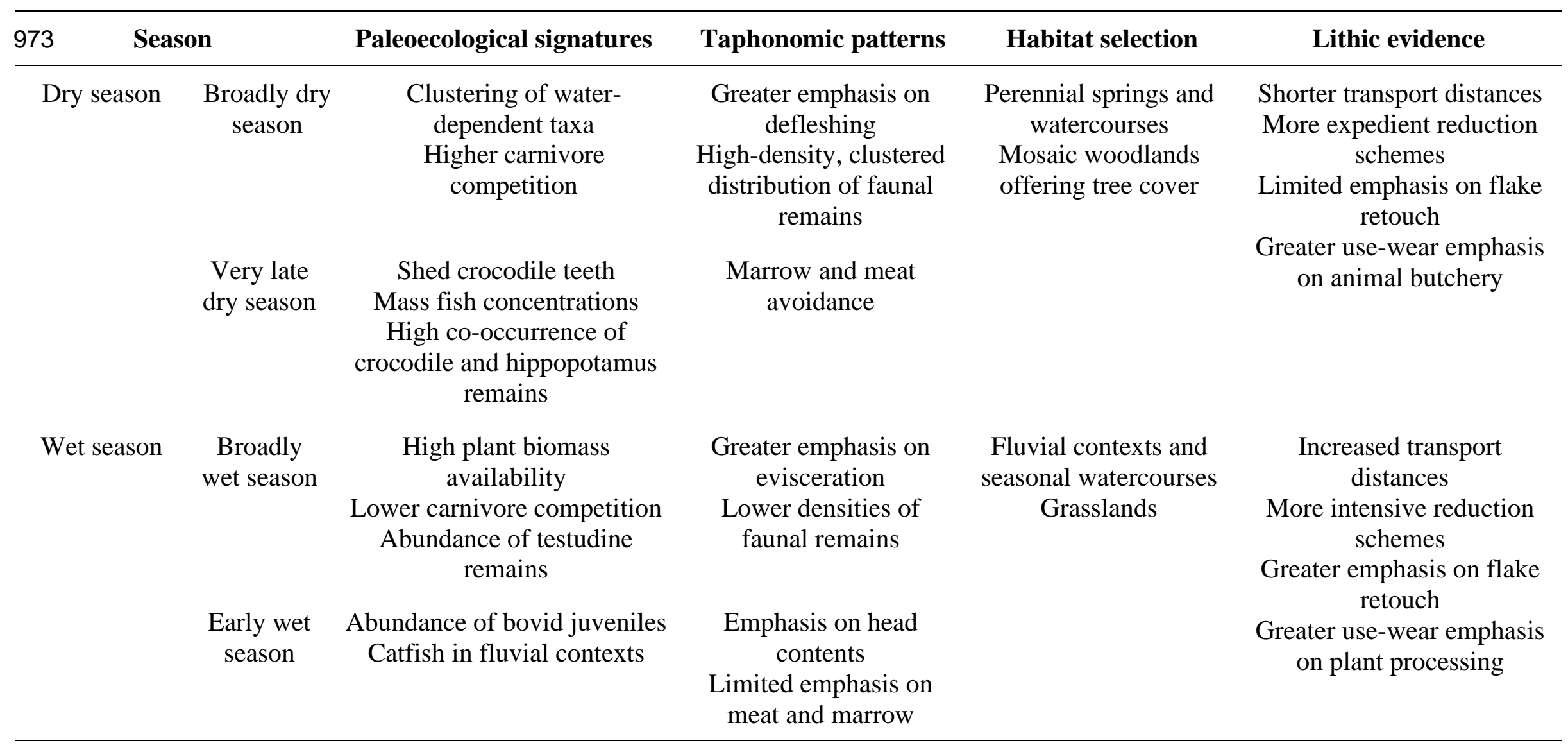


In contrast to HWK-EE, we would suggest that palaeoecological indicators suggest that the

975 bulk of hominin activity at Kanjera South likely occurred in the wet season. The opportunistic

976 availability of medium-large bovid heads from carrion pulses and/or carnivore kills may mean that

977 occupation of the site began in the very late dry, but only the early wet would account for the

978 abundance of juvenile bovids in the context of the renewal of plant biomass in this grassland

979 ecosystem. Furthermore, the aforementioned rarity of water-dependent reduncines at Kanjera

980 South stands in contrast to the predominance of Kobus at FLK-Zinj (Oliver et al., 2019), despite

981 both sites having a perennial water source nearby. Waterbuck are known to show a tight

982 relationship between habitat quality and population density, with feeding areas clustering around

983 water sources in the dry season and dispersing into well-watered open grasslands with the onset of

984 the rains (Tomlinson, 1981; Spinage, 1982; Wirtz and Kaiser, 1988). Therefore, the contrasting

985 patterns of reduncine abundance at FLK-Zinj and Kanjera South are consistent with a broadly wet

986 season attribution to the latter.

987 The prevailing character of the FLK-Zinj lithic assemblage is one of expediency, as indicated

988 by the predominance of unifacial, unidirectional reduction strategies, and only very limited

989 secondary retouch (Leakey, 1971; de la Torre and Mora, 2005; Gallotti, 2018). Some of this

990 reduced investment may be related to the relatively reduced cost of abandoning a local raw

991 material, and indeed different Oldowan sites at Olduvai show a linear reduction in the weight,

992 density, proportion, and reduction intensity of quartzite raw material in the assemblage with

993 distance from the Naibor Soit (Blumenschine et al., 2008). However, there are clear deviations

994 from this trend which may suggest additional ecological influences on the lithic assemblages, with

995 Blumenschine and colleagues (2008) suggesting that the magnitude of the deviations from the

996 distance-decay trend may be related to the extent of task-specific raw material utility 
997 (Blumenschine et al., 2008). Indeed, the functional expediency at FLK-Zinj is underlined by the 998 likely selection of quartzite materials (over the more durable and immediately local lava) for their 999 cutting efficiency (Key et al., 2020).

1000 This contrasts with the pattern at Kanjera South, where selection of materials emphasized 1001 durability over flaking predictability (Braun et al., 2009a). Had Kanjera South shared a similar 1002 emphasis on the fast production and use of raw material with FLK-Zinj, we would have expected 1003 flaking predictability to have been a more important factor in the knapping of material. Instead, 1004 the hominins at the site were willing to accept a greater risk of shorter flakes with less sharp edges 1005 and a greater chance of hinge and step fractures in order to produce more durable cutting edges 1006 (Braun et al., 2009a). This emphasis on tool durability at Kanjera occurs alongside the 1007 aforementioned increased frequency of investment in reduction (particularly bifacial centripetal 1008 reduction schemes), producing longer cutting edges relative to flake mass, and in secondary 1009 retouch, with certain raw materials being transported into the site from $>10 \mathrm{~km}$ away (Braun et al., 1010 2008; Braun et al., 2009a; Braun et al., 2009b; Reeves et al., 2021). This implies a decoupling of 1011 lithic use from specific points on the landscape (cf., Braun and Harris, 2003). In addition, non1012 local materials at Kanjera tend to be among the most durable, and show the most retouch (Braun 1013 et al., 2009a; Braun et al., 2009b; Lemorini et al., 2014), a technological strategy that would have 1014 enhanced further the potential use-life of the tools (Jones, 1981). This trade-off implies that 1015 hominins were planning more abrasive or time-consuming activities such as skinning and/or the 1016 processing of medium-hard plant tissues (Braun et al., 2009a). Indeed, use-wear evidence at 1017 Kanjera South confirms that a substantial quantity of lithic implements were primarily devoted to 1018 the processing of plant resources (Lemorini et al., 2014; Lemorini et al., 2019). Recent 1019 experimental studies have shown that flake retouch and larger flake sizes, which increase force 
1020 loading and manipulability, enhance wood processing efficiency, suggesting that plant resource 1021 manipulation directly influences lithic investment (Bencomo Viala et al., 2020; Gürbüz and Lycett, 1022 2021). These patterns may reflect the establishment of a processing chain to enhance resource 1023 procurement through organic tool use (cf., Pascual-Garrido and Almeida-Warren, 2021).

1024 We use these observations as an empirical basis from which to develop predictions regarding 1025 the relationship between seasonality and technological investment in the Oldowan. According to 1026 evolutionary optimality theory, organisms attempt to maximize a particular currency variable, such 1027 as nutrient return rates, with decisions made according to the costs and benefits of a particular 1028 action, in the context of available constraints (Hawkes et al., 1982; Foley 1985; Stephens and 1029 Krebs, 1986; Winterhalder and Smith, 1992; Ferraro, 2007; Kelly, 2013). In this context, we 1030 emphasize the relevance of seasonal variables, such as competition risk, resource type and quality, 1031 acquisition costs, and resource predictability, for understanding the level of expected technological 1032 investment in lithic assemblages. In Figure 2, these seasonal variables can be considered intra1033 annual constraints on technological development, informing the relative costs (processing 1034 requirements) and benefits (expected returns) on such investment. 
Seasonal Variables

Decision Variables

Outcome

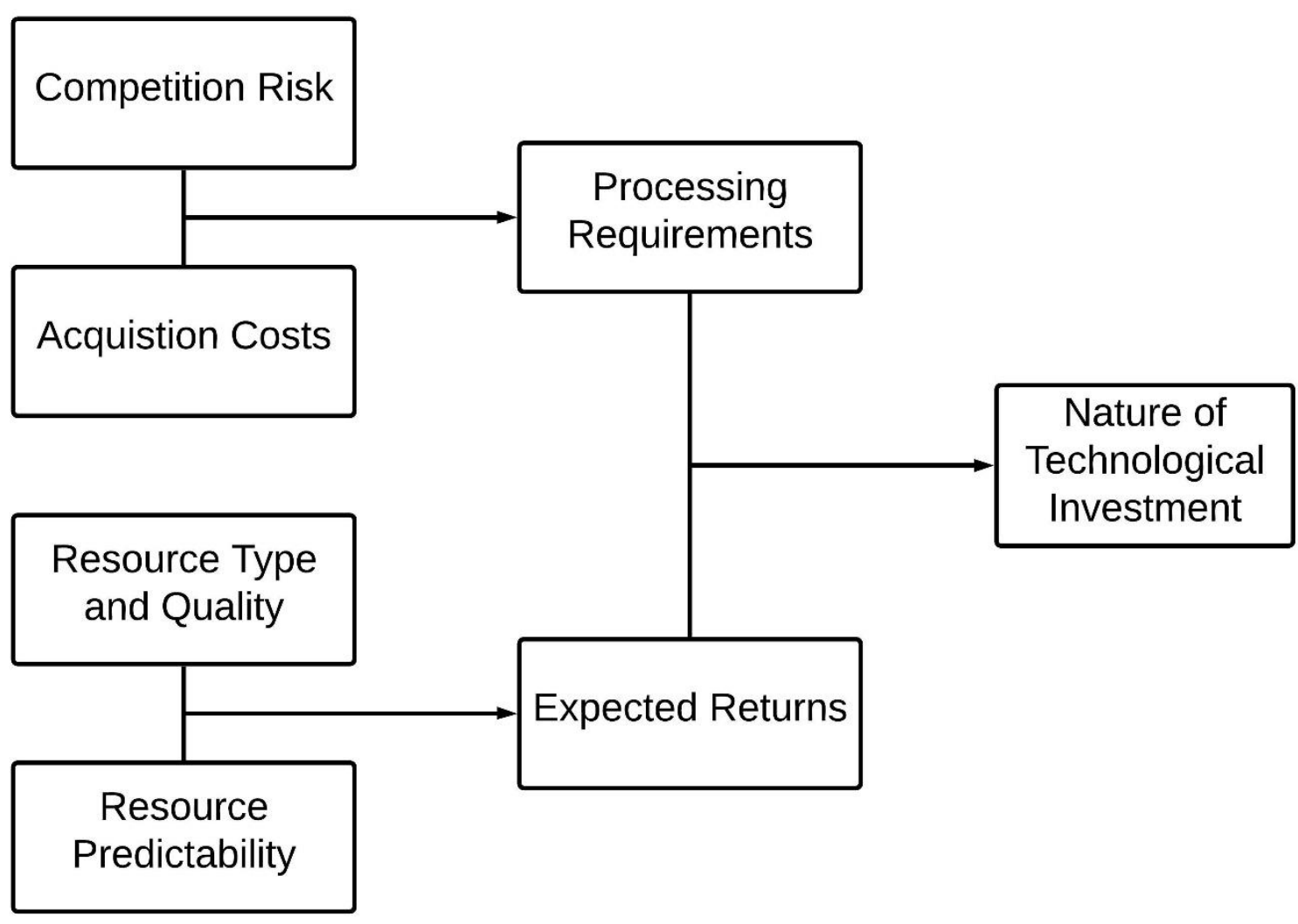

1036 Figure 2. Expected relationship between resource seasonal resource procurement and 1037 technological outcomes in the context of Oldowan.

1038 Faunal acquisition during the Oldowan relied on the relatively unpredictable exploitation of 1039 sparse and mobile resource patches, at least partially through compensatory hunting at both 1040 Kanjera and FLK-Zinj. The use of such hunting strategies is likely to have reduced the 1041 unpredictability of return yields associated with other carcass acquisition strategies, but it still 1042 would not have approached the predictability of distribution and returns seen in plant resources, 1043 particularly during the wet season. Indeed, modern observations of the Hadza suggest men only 1044 succeed in obtaining large carcasses in 1 in 30 hunter-days, remaining as low as 1 in 3 when small 1045 game hunting and trapping was carried out (Hawkes et al., 1991; Hawkes et al., 2001). Given that 1046 Oldowan hominins lacked the technological complexity observed in the Hadza, particularly bows 
1047 and arrows, we can envisage even greater failure rates in the Early Pleistocene. Furthermore, 1048 experimental studies have suggested that retouched flakes are not more effective in this task than 1049 unretouched flakes (Jones, 1994), suggesting that increased investment for predominantly 1050 defleshing purposes will not always produce a corresponding dietary return. In this context, returns 1051 on investment towards carcass processing beyond expedient unretouched flakes upon procurement 1052 would have been minimal relative to costs and relatively unpredictable. Furthermore, the 1053 spatiotemporal co-occurrence of hominins and carnivores in the ecosystem during the dry season 1054 demanded the evaluation of trade-offs between defending or abandoning a carcass before complete 1055 exploitation. Time constraints associated with predation risk have been suggested to directly 1056 influence lithic reduction sequences and Oldowan tool use at Swartkrans, South Africa (Caruana, 1057 2020). Taken together, we would expect a greater emphasis instead on an expedient flake toolkit 1058 capable of fast carcass processing in dry season contexts, as observed at FLK-Zinj.

1059 In contrast, investment in increased handling efficiency is most effective when search costs 1060 are minimal in relation to time spent harvesting and processing a resource (Hawkes and O’Connell, 1061 1992; Hawkes et al., 2018). In the context of increased plant availability and diversity in the wet 1062 season (Sept, 1984), knowledge regarding the abundance and predictability of visible and 1063 embedded resource distributions may have minimized search times and reduced resource 1064 procurement competition (cf., Foley, 1985; Clark and Linares-Matás, 2020). In addition, given the 1065 greater energy density of animal resources (particularly fat: 9 kcal/gram), plant carbohydrates will 1066 generally produce lower caloric return per unit of weight (4 kcal/gram) and unit of handling time 1067 (US National Research Council on Diet and Health, 1989; Stewart, 2014). This further elongates 1068 the required amount of time spent handling these resources to meet caloric requirements (Hawkes 1069 et al., 1982). These factors would have fostered investment towards minimizing handling costs 
1070 and maximizing overall return rates, while also allowing for the ability to foreplan the use of lithic

1071 technology throughout the landscape (Clark and Linares-Matás, 2020). Taken together, we would

1072 therefore expect greater investment in raw material selection and transport (where high-quality

1073 local materials are not available) at wet season sites. This should result in a corresponding increase

1074 in lithic reduction intensity and in the diversity of final forms, including an extent of secondary

1075 retouch. We argue that these patterns are reflected in the relative lithic complexity observed at

1076 Kanjera South (Braun et al., 2009b; Lemorini et al., 2014; Reeves et al., 2021).

1077

1078 5.2. Seasonality and habitat selection in the Oldowan

1079 A recent comparison of faunal exploitation between Kanjera South and FLK-Zinj 1080 emphasized that the affordances of different habitat types, such as grasslands and woodlands, 1081 heavily influenced specific modes of hominin resource acquisition (Oliver et al., 2019). While this 1082 is certainly true, seasonal constraints and opportunities would have actively influenced Oldowan 1083 habitat selection patterns. Predictable response patterns to seasonality-mediated changes in habitat 1084 composition, suitability, and the spatial distribution of preferred resources have been documented 1085 for a wide range of genera across a diversity of heterogeneous ecosystems (e.g., Fleming et al., 1086 1987; Van Schaik et al., 1993; Pape and Löffler, 2015; Vélez et al., 2017; Stanley et al., 2021), 1087 including chimpanzees in forest-woodland mosaic environments (Collins and McGrew, 1988; 1088 Pennec et al., 2020). Moreover, modern human hunter-gatherers show clear patterns of seasonal 1089 movement, with camps tending to be located near perennial water sources during the (late) dry 1090 season (e.g., Hawkes et al., 1997; Lee, 2013). Among the Hadza, wet season camps are more 1091 ephemeral, with repeated camp movement determined by relatively frequent fluctuations in the 1092 spatio-temporal distribution of berries and honey (Hawkes et al., 1997). 
We argue that predictable fluctuations in the spatio-temporal distribution of resources would

1094 have encouraged Oldowan groups to schedule their food-procurement strategies, technological

1095 investment, and preferred habitats on the basis of seasonal constraints and opportunities. The

1096 lakeshore grassland environment at Kanjera South would have enjoyed moist soils and ephemeral

1097 watercourses during the wet season (Ditchfield et al., 2019), which would have profound

1098 implications for plant resource availability and seasonal habitat attractiveness for Oldowan

1099 hominins and other animals. In the context of modern hunter-gatherer seasonal foraging strategies,

1100 the Hadza specifically target environments rich in berries, such as the floodplain of the Barai River

1101 near Lake Eyasi (Vincent, 1985), with the availability of these berries even dictating the location

1102 of many wet season camps (Hawkes et al., 1997). We also note that the probability of finding

1103 medium- to large-sized carcasses with scavenging potential during the wet season in the Serengeti

1104 increases along erosion embankments and the margins of riparian woodlands (Blumenschine,

1105 1987; Hopcraft et al., 2005). In contrast, the mosaic woodland with perennial springs around FLK-

1106 Zinj (Ashley et al., 2010) would have been an attractive dry season hotspot for ungulates,

1107 carnivores, and hominins seeking water and other resources (Hopcraft et al., 2005; Hawkes, 2016).

1108 We also emphasize that our proposed model regarding the nature of lithic investment at

1109 Oldowan sites may be reinforced by raw material management strategies in relation to the length

1110 of site occupation in the face of seasonal variability in habitat selection. In the context of the Late

1111 Pleistocene, Riel-Salvatore and Barton (2004) point out that longer-term occupation of a site,

1112 especially where raw material has been cached, should be associated with reduced intensity of

1113 reduction and curation, as the pressure on preserving raw material is lower. In turn, this should

1114 result in greater artifact densities at such a site, but with an overwhelming focus on unretouched

1115 flakes. Thus, site-level raw material provisioning in the context of a longer duration of 
1116 occupation(s) near perennial water sources during the dry season may have contributed to the

1117 patterns observed at FLK-Zinj. In contrast, in contexts of higher mobility across the landscape and

1118 shorter occupations, hominins should be faced with greater constraints on raw material availability,

1119 resulting in a need to more efficiently utilize (transported) raw material through intensive core

1120 reduction and flake maintenance through edge retouch. This may relate to the technological

1121 patterns observed at Kanjera South (Reeves et al., 2021), in the context of wet season foraging 1122 activities.

\section{5.3. Seasonality and freshwater resource exploitation in the Oldowan}

1125 Terrestrial animal and plant resources were certainly not the only components of Oldowan 1126 diets. In particular, freshwater resources such as crocodiles, testudines, fish, or shellfish would 1127 have offered rich polyunsaturated and Omega-3 fatty acids, as well as trace minerals and vitamins 1128 (Stewart, 1994; Braun et al., 2010; Archer et al., 2014; Cáceres et al., 2017). These resources 1129 exhibit relatively predictable distribution patterns and availability peaks, being most easily 1130 captured during the very late dry and early wet seasons (Stewart, 1994), the periods when terrestrial 1131 animal resources would have been most fat-depleted. Furthermore, the intra-annual patterns of 1132 behavior in many freshwater taxa can act as important paleoecological information for inferring 1133 the seasonality of site formation.

At Olduvai, the fish assemblages $(n=4000)$ of Bed I and II sites exhibit low taxonomic 1135 diversity, likely due to the high salinity and alkalinity values of the Olduvai paleolake (Greenwood 1136 and Todd, 1970; Stewart, 1994). At FLK-Zinj, the assemblage (number of identified specimens $1137[\mathrm{NISP}]=110)$ comprises predominantly catfish $(83.3 \%)$ and cichlids (16.7\%; Stewart, 1994). 1138 While most Olduvai Bed I fish assemblages are likely the result of natural depositional processes, 
1139 FLK-Zinj and FLK-NN have a relatively greater density than natural lacustrine fish scatters, and

1140 an overrepresentation of head versus axial fragments, which may indicate that hominins were

1141 acquiring and processing them (cf., Stewart, 1994). Nonetheless, since the fish assemblage at FLK-

1142 Zinj represents a small proportion of the overall faunal assemblage, fish procurement may have

1143 been opportunistic (Stewart, 1994), perhaps based on the capture of stranded specimens as the

1144 paleolake and seasonal watercourses to the south of the site (Uribelarrea et al., 2014) were receding

1145 during the dry season. Catfish and cichlids are also present within the Kanjera South fish

1146 assemblage (Plummer et al., 1999; Archer et al., 2014), but they do not bear diagnostic surface

1147 modification damage (J. Ferraro, pers. comm.).

1148 A key site for understanding the combined freshwater and terrestrial resource exploitation in

1149 the Oldowan is FwJj20, Koobi Fora Formation, Kenya (1.95 Ma; Braun et al., 2010; Archer et al.,

1150 2014; see Figure 1 above), located within the fluctuating Il Dura fluvio-lacustrine system (Gathogo

1151 and Brown, 2006). Water-dependent species, such as reduncines, tragelaphines, hippopotamids,

1152 and rhinocerotids dominate the terrestrial assemblage, while the sizeable freshwater assemblage

1153 includes turtle, fish, and crocodiles (Braun et al., 2010; Archer et al., 2014). Taphonomic evidence

1154 indicates primary hominin access to the carcasses, with cut-mark distribution data indicating the

1155 practice of evisceration, disarticulation, and defleshing (Braun et al., 2010). Viscera extraction on

1156 terrestrial carcasses is inferred on the basis of cut-marks on the ventral side of a rhinoceros rib (cf.,

1157 Nilssen, 2000), and disarticulation is evident from the presence of cut-marks on a hippopotamus

1158 astragalus and on the glenoid fossa of a bovid scapula (Braun et al., 2010). Flesh removal was

1159 documented on the palmar surface of a crocodile phalanx, which Braun et al. (2010) suggest would

1160 have granted hominins access to the manus muscle mass. The abundance of plastron and carapace

1161 elements indicates that the chelonian assemblage at FwJj20 is anthropogenic in nature (cf., 
1162 Sampson, 2000), while the presence of cut-marks on the ventral surface of a turtle costal carapace

1163 element indicates that evisceration was also being carried out on turtle carcasses (cf., Blasco, 2008;

1164 Braun et al., 2010). With regards to fish, the FwJj20 assemblage (NISP = 405) is dominated by

1165 catfish $(\mathrm{NISP}=365, \mathrm{MNI}=49)$. The catfish skeletal part profiles show an over-representation of

1166 cranial fragments (ca. 75\%; Stewart, 1994; Braun et al., 2010; Archer et al., 2014). Archer et al.

1167 (2014) notes that head over-representation is often the result of butchery processes, as further

1168 evidenced by the presence of cut-marks (mostly on cranial fragments), as well as intentional

1169 fragmentation. $25.5 \%$ of cranial fragments have green breakage planes-with $27.5 \%$ of these

1170 initiated along sutures - and 2.5\% exhibit percussion marks and associated notches (Archer et al.,

1171 2014). On the basis of catfish butchery experiments engaging local Turkana fishing communities,

1172 cranial breakage along sutures using a hammerstone appears to be strongly associated with access

1173 to the fat-rich brain matter (Archer et al., 2014).

1174 Archer et al. (2014) suggest that the main drivers of hominin exploitation of freshwater

1175 resources may have been attempts to reduce energetic investment in resource acquisition, to reduce

1176 technological costs, or to reduce carnivore competition. Additionally, their exploitation may have

1177 been related to seasonal periods of animal depletion and diminishing body fat percentages (Archer

1178 et al., 2014). Carnivore tooth mark patterns on limb bone fragments at FwJj20 (1.9\% NISP)

1179 indicates that carnivore competition in this riparian woodland setting (Bamford, 2011) was lower

1180 than at both the dry season mosaic woodland environment at FLK-Zinj or the wet season open

1181 grassland environment at Kanjera South. As such, rather than representing primarily an attempt to

1182 avoid carnivore competition, we concur that low procurement costs may have facilitated the

1183 seasonal exploitation of fat-rich freshwater resources by hominins. Hominins at FwJj20 appear to

1184 have exploited terrestrial animal resources rather selectively, given the evidence for evisceration 
1185 and skeletal part selection through disarticulation alongside comparatively little evidence for 1186 terrestrial carcass filleting at the site (Braun et al., 2010). Similarly, percussion marks on terrestrial 1187 limb bones are low $(n=4)$, suggesting little emphasis on limb bone marrow nutrients of terrestrial 1188 animals (Braun et al., 2010: Table 2), confirming the overall signature of less intensive carcass 1189 processing than at FLK-Zinj. These taphonomic insights are consistent with a pattern of seasonal 1190 fat-depletion in the flesh and marrow of African ungulates (cf., Sinclair, 1975; Speth, 1987).

1191 On the basis of fish ecology, the reliance on catfish exploitation within a humid fluvio1192 lacustrine context at FwJj20 may also be used to infer seasonality of occupation, as the 1193 aforementioned catfish engage in mass riverine migration towards the onset of the early rainy 1194 season to spawn (Stewart, 1994). Intensive catfish exploitation in a fluvial context has also been 1195 reported at BK in Olduvai Bed II, and was used by Stewart (1994) to infer a very late dry to early 1196 wet season context, potentially allowing the same deduction to be applied to FwJj20. A hominin 1197 presence spanning this seasonal transition would also be consistent with the diverse 1198 paleoecological signatures observed at the site. For example, the high density of water-dependent 1199 reduncine remains and the co-occurrence of abundant crocodile and hippopotamid remains would 1200 indicate late dry season, while the high proportion of chelonid, in relation to bovid NISP values 1201 would be suggestive of wet season (cf., Speth and Davis, 1976). Embedded fish resources, such as 1202 the energy-dense head content of catfish, appear to have been particularly desirable to the FwJj20 1203 hominins (Archer et al., 2014). Since catfish brains have a similar metabolic composition to 1204 mammalian brains (Du et al., 2018), they likely performed a similar dietary function at FwJj20 to 1205 the large bovid heads and mandibles processed at Kanjera South (Ferraro et al., 2013) in the 1206 seasonal food-procurement schedules of early Homo. It is also possible that the cut-marks found 1207 on a crocodile skull fragment at Gona OGS-6 (Cáceres et al., 2017) may have similarly been 
1208 produced during butchery processes that targeted within-head contents, in addition to adhering

1209 flesh. We anticipate that further publications on the technological sequences and use-wear of the

1210 lithics of FwJj20 will allow for more holistic comparisons with other Oldowan sites.

1211

1212 6. Conclusions

1213 In this paper, we have attempted to derive a framework for interpreting the influence of 1214 seasonality on hominin behavior within the Oldowan record, using patterns of resource 1215 consumption and lithic investment at FLK-Zinj and Kanjera South as a lens through which 1216 behavioral variability can be studied. On the basis of zooarcheological assessments of mortality 1217 profiles and the taphonomic evidence for early hominin access to carcasses, we argue that at least 1218 some extent of compensatory hunting is a shared feature of both sites. Nonetheless, there are 1219 differences in prey demographics that can be related to seasonal cycles of vulnerability, matching 1220 expectations derived from actualistic observations of carnivore feeding behavior (Owen-Smith,

1221 2008; Pereira et al., 2014; Arriaza et al., 2015). The ability to achieve primary access to terrestrial 1222 ungulates in different seasons may be indicative of novel foraging behaviors that enhanced overall 1223 resource yields from patchy resources. Late Oldowan hominins may have relied on social networks 1224 to identify and pursue carcass acquisition opportunities, while keeping predators away in the 1225 process. At the same time, we emphasize that the relative relevance of certain animal resources in 1226 Oldowan diets was a distinctly seasonal phenomenon. For example, fat-depleted meat would have 1227 been less attractive during periods of nutritional stress (cf., Speth, 1987), such as the very late dry 1228 season and the early wet season. In these contexts, energy-dense resources such as ungulate head 1229 contents, plant carbohydrates, nuts, and freshwater taxa would have been particularly desirable. 
We further argue that seasonal changes to food-procurement strategies, partially mediated

1231 through habitat selection, would have contributed to the patterning of techno-economic behavior.

1232 Embedded social landscape knowledge would have been an underlying requirement in hominin

1233 awareness of changing resource distribution patterns and the ability to successfully track and 1234 exploit those resources (Clark and Linares-Matás, 2020). Animal resource exploitation involving 1235 fast and comprehensive carcass processing upon procurement encouraged greater lithic 1236 expediency at dry season sites, especially when facilitated by raw material place provisioning, as 1237 interpreted for FLK-Zinj. In contrast, the nutritional constraints associated with the consumption 1238 of fat-depleted terrestrial animal resources during the very late dry season and the early wet season 1239 actively encouraged hominins to engage in the preferential selection of fat-rich skeletal parts, such 1240 as head contents, mandibular nerve and marrow, and viscerae. Freshwater aquatic resources would 1241 have also provided a source of fatty acids at this time of the year, as discussed in relation to FwJj20. 1242 The availability, predictability, and dietary relevance of plant resources during the early-mid wet 1243 season would have encouraged hominins to shift their overall dietary emphasis towards 1244 carbohydrate-rich plants. In this context, planning of subsistence behaviors through the landscape 1245 and investment in raw material transport and/or lithic reduction schemes may have allowed for 1246 reduced resource acquisition and processing costs, either directly or for the production of suitable 1247 tools on organic materials. We propose that these seasonal dynamics could help explain the 1248 archeological record of Kanjera South. We suggest that the consolidation and subsequent 1249 elaboration of these behavioral patterns allowed early Homo to more successfully negotiate 1250 seasonal variability in resource predictability and habitat structure from the Early Pleistocene 1251 onwards. 


\section{Acknowledgments}

1254 We wish to thank the Editors-in-Chief of Journal of Human Evolution (Andrea B. Taylor and 1255 Clément Zanolli) for considering the submission of this manuscript, as well as the anonymous 1256 Associate Editor and three reviewers for their very helpful comments. We are also very grateful to 1257 Robert Foley (King's College, University of Cambridge), Peter Mitchell (St. Hugh's College, 1258 University of Oxford), and Nick Barton (Hertford College, University of Oxford) for their initial 1259 encouragement and insightful suggestions. We extend our gratitude to the following scholars, who 1260 took the time to read our work and provided feedback and discussed ideas present in earlier 1261 versions of this manuscript: Henry Bunn (University of Wisconsin-Madison), Lucía Cobo1262 Sánchez (Universidad Complutense de Madrid), Manuel Domínguez-Rodrigo (Universidad de 1263 Alcalá), Joseph V. Ferraro (Baylor University), Kristen Hawkes (University of Utah), James 1264 O'Connell (University of Utah), James Oliver (Pennsylvania State University), Jennifer Parkinson 1265 (University of San Diego), Thomas Plummer (Queens College, City University of New York), 1266 John D. Speth (University of Michigan), Kathlyn Stewart (Canadian Museum of Nature), Michael 1267 J. Walker (Universidad de Murcia), and José Yravedra (Universidad Complutense de Madrid). We 1268 also thank our friend Jonathan Lim (University of Oxford) for crafting the map used in Figure 1 in 1269 ArcGIS. The research of G.L.M. was supported by the Arts and Humanities Research Council 1270 (grant number AH/R012709/1) through a Baillie Gifford AHRC Scholarship (OOC-DTP program)

1271 for his Ph.D. in Archaeology at St. Hugh's College, University of Oxford (UK). The research of 1272 J.C. was supported by the Arts and Humanities Research Council (grant number AH/R012709/1) 1273 through a St. John's College Match-funded Studentship (OOC-DTP program) for his Ph.D. in 1274 Biological Anthropology at St. John's College, University of Cambridge (UK). 


\section{References}

1276 Aiello, L.C., Wheeler, P., 1995. The expensive-tissue hypothesis: The brain and the digestive 1277 system in human and primate evolution. Current Anthropology 36, 199-221. 1278 https://doi.org/10.1086/204350

1279 Aramendi, J., Maté-González, M.A., Yravedra, J., Ortega, M.C., Arriaza, M.C., González1280 Aguilera, D., Baquedano, E., Domínguez-Rodrigo, M., 2017. Discerning carnivore agency 1281 through the three-dimensional study of tooth pits: Revisiting crocodile feeding behaviour at 1282 FLK- Zinj and FLK NN3 (Olduvai Gorge, Tanzania). Palaeogeography, Palaeoclimatology, 1283 Palaeoecology 488, 93-102. https://doi.org/10.1016/j.palaeo.2017.05.021

1285 Archer, W., Braun, D.R., Harris, J.W.K., McCoy, J.T., Richmond, B.G., 2014. Early Pleistocene 1286 aquatic resource use in the Turkana Basin. Journal of Human Evolution 77, 74-87. 1287 https://doi.org/10.1016/j.jhevol.2014.02.012

1288 Arráiz, H., Barboni, D., Ashley, G.M., Mabulla, A., Baquedano, E., Domínguez-Rodrigo, M., 1289 2017. The FLK Zinj paleolandscape: reconstruction of a 1.84 Ma wooded habitat in the FLK 1290 Zinj-AMK-PTK-DS archaeological complex, Middle Bed I (Olduvai Gorge, Tanzania). 1291 Palaeogeography, Palaeoclimatology, and Palaeoecology 488, 9-20. 1292 https://doi.org/10.1016/j.palaeo.2017.04.025

1293 Arriaza, M.C., Domínguez-Rodrigo, M., Martínez-Maza, C., Mabulla, A., Baquedano, E., 2015.

1294 Differential predation by age and sex classes in blue wildebeest in Serengeti: Study of a

1295 modern carnivore den in Olduvai Gorge (Tanzania). PLoS ONE 10, e0125944.

1296 https://doi.org/10.1371/journal.pone.0125944 
1297 Arroyo, A., de la Torre, I., 2016. Assessing the function of pounding tools in the Early Stone 1298 Age: A microscopic approach to the analysis of percussive artefacts from Beds I and II, 1299 Olduvai Gorge (Tanzania). Journal of Archaeological Science 74, $23-34$.

1300 https://doi.org/10.1016/j.jas.2016.08.003

1301 Arroyo, A., de la Torre, I., 2018. Pounding tools in HWK EE and EF-HR (Olduvai Gorge, 1302 Tanzania): Percussive activities in the Oldowan-Acheulean transition. Journal of Human 1303 Evolution 120, 402-421. https://doi.org/10.1016/j.jhevol.2017.10.005

1304 Arroyo, A., Hirata, S., Matsuzawa, T., Torre, I. de la, 2016. Nut cracking tools used by captive 1305 chimpanzees (Pan troglodytes) and their comparison with Early Stone Age percussive 1306 artefacts from Olduvai Gorge. PLoS ONE 11, e0166788.

1307 https://doi.org/10.1371/journal.pone.0166788

1308 Ashley, G.M., Barboni, D., Dominguez-Rodrigo, M., Bunn, H.T., Mabulla, A.Z.P., Diez-Martin, 1309 F., Barba, R., Baquedano, E., 2010. A spring and wooded habitat at FLK Zinj and their 1310 relevance to origins of human behavior. Quaternary Research 74, 304-314. 1311 https://doi.org/10.1016/j.yqres.2010.07.015

1312 Ashley, G.M., Tactikos, J.C., Owen, R.B., 2009. Hominin use of springs and wetlands: 1313 Paleoclimate and archaeological records from Olduvai Gorge ( 1.79-1.74 Ma). 1314 Palaeogeography, Palaeoclimatology, Palaeoecology 272, 1-16. 1315 https://doi.org/10.1016/j.palaeo.2008.10.016

1316 Audet, J.N., Lefebvre, L., 2017. What's flexible in behavioral flexibility? Behavioral Ecology 28, 1317 943-947. https://doi.org/10.1093/beheco/arx007 
1318 Backwell, L.R., d'Errico, F., 2001. Evidence of termite foraging by Swartkrans early hominids.

1319 Proceedings of the National Academy of Sciences USA 98, 1358-1363.

1320 https://doi.org/10.1073/pnas.98.4.1358

1321 Bamford, M.K., 2011. Late Pliocene woody vegetation of Area 41, Koobi Fora, East Turkana

1322 Basin, Kenya. Review of Palaeobotany and Palynology 164, 191-210.

1323 https://doi.org/10.1016/j.revpalbo.2011.01.004

1324 Bartram, L.E., Kroll, E.M., Bunn, H.T. 1991. Variability in camp structure and bone food refuse

1325 patterning at Kua San hunter-gatherer camps. In: Kroll. E.M., Douglas Price, T. (Eds.), The

1326 Interpretation of Archaeological Spatial Patterning. Plenum Press, New York, pp. 77-148.

1327 https://doi.org/10.1007/978-1-4899-2602-9_5

1328 Behrensmeyer, A.K., 1978. Taphonomic and ecologic information from bone weathering.

1329 Paleobiology 4, 150-162. https://doi.org/10.1017/S0094837300005820

1330 Behrensmeyer, A.K., Potts, R., Plummer, T., Tauxe, L., Opdyke, N., Jorstad, T., 1995. The

1331 Pleistocene locality of Kanjera, western Kenya: stratigraphy, chronology and

1332 paleoenvironments. Journal of Human Evolution 29, 247-274.

1333 https://doi.org/10.1006/jhev.1995.1059

1334 Bello-Alonso, P., Rios-Garaizar, J., Panera, J., Pérez-González, A., Rubio-Jara, S., Rojas-

1335 Mendoza, R., Domínguez-Rodrigo, M., Baquedano, E., Santonja, M., 2019. A use-wear

1336 interpretation of the most common raw materials from the Olduvai Gorge: Naibor Soit quartzite.

1337 Quaternary International 526, 169-192. https://doi.org/10.1016/j.quaint.2019.09.025

1338 Bencomo Viala, M., Jardón Giner, P., Sirvent Cañada, L.M., Hortelano Piqueras, L., 2020.

1339 Understanding woodworking in Paleolithic times by means of use-wear analysis. Journal of

1340 Archaeological Science: Reports 29, 102119. https://doi.org/10.1016/j.jasrep.2019.102119 
1341 Ben-Dor, M., Gopher, A., Hershkovitz, I., Barkai, R., 2011. Man the Fat Hunter: The demise of 1342 Homo erectus and the emergence of a new hominin lineage in the Middle Pleistocene (ca. 400 1343 kyr) Levant. PLoS ONE 6, e28689. https://doi.org/10.1371/journal.pone.002868

1344 Beverly, E.J., Ashley, G.M., Driese, S.G., 2014. Reconstruction of a Pleistocene paleocatena using 1345 micromorphology and geochemistry of lake margin paleo-Vertisols, Olduvai Gorge, Tanzania. 1346 Quaternary International 322-323, 78-94. https://doi.org/10.1016/j.quaint.2013.10.005

1347 Bibi, F., Pante, M., Souron, A., Stewart, K., Varela, S., Werdelin, L., Boisserie, J.-R., Fortelius, 1348 M., Hlusko, L., Njau, J., de la Torre, I., 2018. Paleoecology of the Serengeti during the 1349 Oldowan-Acheulean transition at Olduvai Gorge, Tanzania: The mammal and fish evidence. 1350 Journal of Human Evolution 120, 48-75. https://doi.org/10.1016/j.jhevol.2017.10.009

1351 Binford, L.R., 1978. Nunamiut Ethnoarchaeology. Academic Press, New York.

1352 Binford, L.R., 1979. Organization and formation processes: Looking at curated technologies. 1353 Journal of Anthropological Research 35, 255-273. https://doi.org/10.1086/jar.35.3.3629902 1354 Binford, L.R., 1981. Bones: Ancient men and modern myths. Academic Press, Orlando. 1355 Binford, L.R., 1985. Human ancestors: changing views of their behaviour. Journal of 1356 Anthropological Archaeology 4, 292-327. https://doi.org/10.1016/0278-4165(85)90009-1

1357 Blasco, R., 2008. Human consumption of tortoises at level IV of Bolomor Cave (Valencia, Spain). 1358 Journal of Archaeological Science 35, 2839-2848. https://doi.org/10.1016/j.jas.2008.05.013 1359 Blumenschine, R.J., 1986. Early hominid scavenging opportunities: implications of carcass 1360 availability in the Serengeti and Ngorongoro ecosystems. British Archaeological Reports, $1361 \quad$ Oxford.

1362 Blumenschine, R.J., 1987. Characteristics of an early hominid scavenging niche. Current 1363 Anthropology 28, 383-407. https://doi.org/10.1086/203544 
1364 Blumenschine, R.J., 1988. An experimental model of the timing of hominid and carnivore 1365 influence on archaeological bone assemblages. Journal of Archaeological Science 15, 483-502. 1366 https://doi.org/10.1016/0305-4403(88)90078-7

1367 Blumenschine, R.J., 1991. Hominid carnivory and foraging strategies, and the socioeconomic 1368 function of early archaeological sites. Philosophical Transactions of the Royal Society 334, 1369 211-221. https://doi.org/10.1098/rstb.1991.0110

1370 Blumenschine, R.J., 1995. Percussion marks, tooth marks, and experimental determination of the 1371 timing of homind and carnivore access to long bones at FLK Zinjanthropus, Olduvai Gorge, 1372 Tanzania. Journal of Human Evolution 29, 21-51. https://doi.org/10.1006/jhev.1995.1046

1373 Blumenschine, R.J., Cavallo, J.A., Capaldo, S.D., 1994. Competition for carcasses and early 1374 hominid behavioral ecology: a case study and conceptual framework. Journal of Human 1375 Evolution 27, 197-213. https://doi.org/10.1006/jhev.1994.1042

1376 Blumenschine, R.J., Madrigal, T.C., 1993. Variability in long bone marrow yields of East African 1377 ungulates and its zooarchaeological implications. Journal of Archaeological Science 20, 555$1378 \quad 587$. https://doi.org/10.1006/jasc.1993.1034

1379 Blumenschine, R.J., Marean, C.W., 1993. A carnivore's view of archaeological bone assemblages. 1380 In: Hudson, J. (Ed.), From Bones to Behavior: Ethno-archaeological and Experimental 1381 Contributions to the Interpretation of Zooarchaeological Remains, Center for Archaeological 1382 Investigations, University of Southern Illinois, Carbondale, pp. 273-300.

1383 Blumenschine, R.J., Masao, F.T., Tactikos, J.C., Ebert, J.I., 2008. Effects of distance from stone 1384 source on landscape-scale variation in Oldowan artifact assemblages in the Paleo-Olduvai 1385 Basin, Tanzania. Journal of Archaeological Science 35, 76-86. $1386 \quad$ https://doi.org/10.1016/j.jas.2007.02.009 
Blumenschine, R.J., Stanistreet, I.G., Njau, J.K., Bamford, M.K., Masao, F.T., Albert, R.M., 1388 Stollhofen, H., Andrews, P., Prassack, K.A., McHenry, L.J., Fernández-Jalvo, Y., Camilli, E.L., Ebert, J.I., 2012. Environments and hominin activities across the FLK Peninsula during Zinjanthropus times (1.84 Ma), Olduvai Gorge, Tanzania. Journal of Human Evolution 63, 364-383. https://doi.org/10.1016/j.jhevol.2011.10.001

Blumenthal, S.A., Cerling, T.E., Smiley, T.M., Badgley, C.E., Plummer, T.W., 2019. Isotopic records of climate seasonality in equid teeth. Geochimica et Cosmochimica Acta 260, 329-348. https://doi.org/10.1016/j.gca.2019.06.037

Bobe, R., Behrensmeyer, A.K., 2004. The expansion of grassland ecosystems in Africa in relation to mammalian evolution and the origin of the genus Homo. Palaeogeography, Palaeoclimatology, Palaeoecology 207, 399-420. https://doi.org/10.1016/j.palaeo.2003.09.033

Boesch, C., Boesch, H., 1989. Hunting behavior of wild chimpanzees in the Taï National Park. American Journal of Physical Anthropology 78, 547-573. 1404 DiMaggio, E.N., Dupont-Nivet, G., Engda, B., Feary, D.A., Garello, D.I., Kerfelew, Z., 1405 McPherron, S.P., Patterson, D.B., Reeves, J.S., Thompson, J.C., Reed, K.E., 2019. Earliest 1406 known Oldowan artifacts at >2.58 Ma from Ledi-Geraru, Ethiopia, highlight early technological 1407 diversity. Proceedings of the National Academy of Sciences USA 116, 11712-11717. 1408 https://doi.org/10.1073/pnas.1820177116 
1409 Braun, D.R., Harris, J.W.K., 2003. Technological developments in the Oldowan of Koobi Fora: 1410 Innovative techniques of artifact analysis. In: Moreno, J.M., Mora Torcal, R., de la Torre Sainz, 1411 I. (Eds.), Treballs d'Arqueologia, 9. Oldowan: Rather more than smashing stones. First Hominid 1412 Technology Workshop, Bellaterra, December 2001. Centre d'Estudis del Patrimoni 1413 Arqueològic de la Prehistòria, Universitat Autònoma de Barcelona, Barcelona, pp. 117-144.

1414 Braun, D.R., Harris, J.W.K., Levin, N.E., McCoy, J.T., Herries, A.I.R., Bamford, M.K., Bishop, 1415 L.C., Richmond, B.G., Kibunjia, M., 2010. Early hominin diet included diverse terrestrial and 1416 aquatic animals $1.95 \mathrm{Ma}$ in East Turkana, Kenya. Proceedings of the National Academy of 1417 Sciences USA 107, 10002-10007. https://doi.org/10.1073/pnas.1002181107

1418 Braun, D.R., Plummer, T.W., Ditchfield, P., Ferraro, J.V., Maina, D., Bishop, L.C., Potts, R., 2008. 1419 Oldowan behavior and raw material transport: perspectives from the Kanjera Formation. 1420 Journal of Archaeological Science 35, 2329-2345. https://doi.org/10.1016/j.jas.2008.03.004

1421 Braun, D.R., Plummer, T.W., Ditchfield, P.W., Bishop, L.C., Ferraro, J.V., 2009b. Oldowan 1422 technology and raw material variability at Kanjera South. In: Hovers, E., Braun, D.R. (Eds.), 1423 Interdisciplinary Approaches to the Oldowan. Springer Netherlands, Dordrecht, pp. 99-110. 1424 https://doi.org/10.1007/978-1-4020-9060-8_9

1425 Braun, D.R., Plummer, T.W., Ferraro, J.V., Ditchfield, P., Bishop, L.C., 2009a. Raw material 1426 quality and Oldowan hominin toolstone preferences: evidence from Kanjera South, Kenya. 1427 Journal of Archaeological Science 36, 1605-1614. https://doi.org/10.1016/j.jas.2009.03.025

1428 Brelsford, W.V., 1946. Fishermen of the Bangweulu swamps. Rhodes-Livingstone Institute, 1429 Livingstone, Zambia.

1430 Broadhurst, C.L., Wang, Y., Crawford, M.A., Cunnane, S.C., Parkington, J.E., Schmidt W.F., 1431 2002. Brain-specific lipids from marine, lacustrine, or terrestrial food resources: Potential 
1432 impact on early African Homo sapiens. Comparative Biochemistry and Physiology Part B:

1433 Biochemistry and Molecular Biology 131, 653-673. https://doi.org/10.1016/S1096-

$1434 \quad 4959(02) 00002-7$

1435 Bunn, H.T., 1981. Archaeological evidence for meat-eating by Plio-Pleistocene hominids from 1436 Koobi Fora and Olduvai Gorge. Nature. 291, 574-577. https://doi.org/10.1038/291574a0

1437 Bunn, H.T., 1986. Patterns of skeletal representation and hominid subsistence activities at Olduvai 1438 Gorge, Tanzania, and Koobi Fora, Kenya. Journal of Human Evolution 15, 673-690. 1439 https://doi.org/10.1016/S0047-2484(86)80004-5

1440 Bunn, H.T., 2001. Hunting, power scavenging, and butchering by Hadza foragers and by Plio1441 Pleistocene Homo. In: Stanford, C.B., Bunn, H.T. (Eds.), Meat-Eating and Human Evolution. 1442 Oxford University Press, Oxford, pp. 199-218.

1443 Bunn, H.T., 2007. Meat made us human. In: Ungar, P.S. (Ed.), Evolution of the Human Diet: The 1444 Known, the Unknown, and the Unknowable. Oxford University Press, Oxford, pp. 191-211

1445 Bunn, H.T., Bartram, L.E., Kroll, E.M., 1988. Variability in bone assemblage formation from 1446 Hadza hunting, scavenging, and carcass processing. Journal of Anthropological Archaeology 1447 7, 412-457. https://doi.org/10.1016/0278-4165(88)90004-9

1448 Bunn, H.T., Ezzo, J.A., 1993. Hunting and scavenging by Plio-Pleistocene hominids: Nutritional 1449 constraints, archaeological patterns, and behavioural implications. Journal of Archaeological 1450 Science 20, 365-398. https://doi.org/10.1006/jasc.1993.1023

1451 Bunn, H.T., Gurtov, A.N., 2014. Prey mortality profiles indicate that Early Pleistocene Homo at 1452 Olduvai was an ambush predator. Quaternary International 322-323, 44-53. 1453 https://doi.org/10.1016/j.quaint.2013.11.002 
1454 Bunn, H.T., Harris, J.W.K., Isaac, G., Kaufulu, Z., Kroll, E., Schick, K., Toth, N., Behrensmeyer, 1455 A.K., 1980. FxJj50: An early Pleistocene site in northern Kenya. World Archaeology 12, 1091456 136. https://doi.org/10.1080/00438243.1980.9979787

1457 Bunn, H.T., Kroll, E.M. 1986. Systematic butchery by Plio-Pleistocene hominids at Olduvai 1458 Gorge, Tanzania. Current Anthropology 27, 431-452. https://doi.org/10.1086/203467

1459 Bunn, H.T., Pickering, T.R., 2010. Bovid mortality profiles in paleoecological context falsify 1460 hypotheses of endurance running-hunting and passive scavenging by early Pleistocene 1461 hominins. Quaternary Research 74, 395-404. https://doi.org/10.1016/j.yqres.2010.07.012

1462 Butzer, K.W., 1982. Archaeology as Human Ecology. Cambridge University Press, Cambridge.

1463 Cáceres, I. Rogers, M.J., Semaw, S., Leiss, A.C., 2017. Crocodiles in the diet of the first Oldowan 1464 toolmakers: evidence from OGS-6 at Gona (Afar, Ethiopia). III Jornadas de Prehistoria 1465 Africana 2017, 20. https://cir.cenieh.es/handle/20.500.12136/944

1466 Camarós, E., Cueto, M., Teira, L.C., Tapia, J., Cubas, M., Blasco, R., Rosell, J., Rivals, F., 2013. 1467 Large carnivores as taphonomic agents of space modification: an experimental approach with 1468 archaeological implications. Journal of Archaeological Science 40, 1361-1368. 1469 https://doi.org/10.1016/j.jas.2012.09.037

1470 Capaldo, S.D., 1997. Experimental determinations of carcass processing by Plio-Pleistocene 1471 hominids and carnivores at FLK 22 (Zinjanthropus) Olduvai Gorge, Tanzania. Journal of 1472 Human Evolution 33, 555-597. https://doi.org/10.1006/jhev.1997.0150

1473 Capaldo, S.D., Peters, C.R., 1995. Skeletal inventories from wildebeest drownings at Lakes Masek 1474 and Ndutu in the Serengeti ecosystem of Tanzania. Journal of Archaeological Science 22, 385$1475 \quad$ 408. https://doi.org/10.1006/jasc. 1995.0039 
1476 Caruana, M.V., 2020. Exploring the influence of predation risks on Oldowan tool use in South 1477 $\begin{array}{lllll}\text { Africa. Journal of } & \text { Field }\end{array}$

$1478 \quad$ https://doi.org/10.1080/00934690.2020.1813394

1479 Cerling, T.E., Wynn, J.G., Andanje, S.A., Bird, M.I., Korir, D.K., Levin, N.E., Mace, W., 1480 Macharia, A.N., Quade, J., Remien, C.H., 2011. Woody cover and hominin environments in 1481 the past 6 million years. Nature 476, 51-56. https://doi.org/10.1038/nature10306

1482 Chamaille-Jammes, S., Fritz, H., Valeix, M., Murindagomo, F., Clobert, J. 2008. Resource 1483 variability, aggregation and direct density dependence in an open context: the local regulation 1484 of an African elephant population. Journal of Animal Ecology 77, 5-144. 1485 https://doi.org/10.1111/j.1365-2656.2007.01307.x

1486 Child, G., Richter, W.V., 1969. Observation on ecology and behaviour of lechwe, puku and 1487 waterbuck along the Chobe River, Botswana. Zeitschrift für Säugetierkunde 34, 275-295.

1488 Clark, J., Linares-Matás, G.J., 2020. The role of landscape knowledge networks in the Early 1489 Pleistocene technological variability of East Africa. Archaeological Review from Cambridge $1490 \quad 35.2,25-44$. https://doi.org/10.17863/CAM.71847

1491 Cobo-Sánchez, L., 2020. Taphonomic and Spatial Study of the Archaeological Site DS from Bed 1492 I in Olduvai Gorge (Tanzania). Ph.D. Dissertation, Universidad Complutense de Madrid.

1493 Collins, D.A., McGrew, W.C., 1988. Habitats of three groups of chimpanzees (Pan troglodytes) 1494 in western Tanzania compared. Journal of Human Evolution 17, 553-574. 1495 https://doi.org/10.1016/0047-2484(88)90084-X

1496 Cordain, L., Miller, J.B., Eaton, S.B., Mann, N., Holt, S.H., Speth, J.D., 2000. Plant-animal 1497 subsistence ratios and macronutrient energy estimations in worldwide hunter-gatherer diets. 1498 The American Journal of Clinical Nutrition 71, 682-692. https://doi.org/10.1093/ajcn/71.3.682 
1499 Cordain, L., Watkins, B.A., Florant, G.L., Kelher, M., Rogers, L., Li, Y., 2002. Fatty acid analysis 1500 of wild ruminant tissues: evolutionary implications for reducing diet-related chronic disease. 1501 European Journal of Clinical Nutrition 56, 181-191. https://doi.org/10.1038/sj.ejcn.1601307

1502 Cordain, L., Watkins, B.A., Mann, N.J., 2001. Fatty acid composition and energy density of foods 1503 available to African hominids. In: Simopoulos, A.P., Pavlou, K.N. (Eds.), Nutrition and Fitness: 1504 Metabolic Studies in Health and Disease. Karger, Basel, pp. 144-161.

1505 Corey, M. 2021. Raiding a baboon camp with Hadza hunter-gatherers in Tanzania. YouTube. 1506 https://www.youtube.com/watch?v=Ny4bHOnSg0o (Timestamp, 5:22; Last Accessed $1507 \quad 14 / 05 / 2021)$

1508 Davidson Z, Valeix M, Van Kesteren F, Loveridge AJ, Hunt JE, Murindagomo F, MacDonald, 1509 D.W. 2013. Seasonal diet and prey preference of the African lion in a waterhole-driven semi1510 arid savanna. PLoS ONE 8, e55182. https://doi.org/10.1371/journal.pone.0055182

1511 d'Errico, F., Backwell., L., 2009. Assessing the function of early hominin bone tools. Journal of 1512 Archaeological Science 36, 1764-1773. https://doi.org/10.1016/j.jas.2009.04.005

1513 de Heinzelin, J., Clark, J.D., White, T., Hart, W., Renne, P., WoldeGabriel, G., Beyene, Y., Vrba, 1514 E., 1999. Environment and behavior of 2.5-Million-Year-Old Bouri hominids. Science 284, $1515 \quad 625-629$. https://doi.org/10.1126/science.284.5414.625

1516 de la Torre, I., Benito-Calvo, A., Arroyo, A., Zupancich, A., Proffitt, T., 2013. Experimental 1517 protocols for the study of battered stone anvils from Olduvai Gorge (Tanzania). Journal of 1518 Archaeological Science 40, 313-332. https://doi.org/10.1016/j.jas.2012.08.007

1519 de la Torre, I., Mora, R., 2005. Technological strategies in the Lower Pleistocene at Olduvai Beds 1520 I \& II. Universite de Liége, Service de Prehistoire, Liége. 
1521 deMenocal, P.B., 1995. Plio-Pleistocene African climate. Science 270, 53-59. 1522 https://doi.org/10.1126/science.270.5233.53

1523 deMenocal, P.B., 2004. African climate change and faunal evolution during the Pliocene1524 Pleistocene. Earth and Planetary Science Letters 220, 3-24. https://doi.org/10.1016/S0012$1525 \quad 821 X(04) 00003-2$

1526 Dickinson, A., 1981. Conditioning and associative learning. British Medical Bulletin 37, 165-168. 1527 https://doi.org/10.1093/oxfordjournals.bmb.a071695

1528 Ditchfield, P.W., Whitfield, E., Vincent, T., Plummer, T., Braun, D., Deino, A., Hertel, F., Oliver, 1529 J.S., Louys, J., Bishop, L.C., 2019. Geochronology and physical context of Oldowan site 1530 formation at Kanjera South, Kenya. Geological Magazine 156, 1190-1200. $1531 \quad$ https://doi.org/10.1017/S0016756818000602

1532 Domínguez-Rodrigo, M., 1994. Dinámica trófica, estrategias de consumo y alteraciones óseas en 1533 la sabana africana: resumen de un proyecto de investigación etnoarqueológico (1991-1993). 1534 Trabajos De Prehistoria 51, 15-37. https://doi.org/10.3989/tp.1994.v51.i1.462

1535 Domínguez-Rodrigo, M., 1997. Meat-eating by early hominids at the FLK 22 Zinjanthropus site, 1536 Olduvai Gorge (Tanzania): an experimental approach using cutmark data. Journal of Human 1537 Evolution 33, 669-690. https://doi.org/10.1006/jhev.1997.0161

1538 Domínguez-Rodrigo, M., 1999. Flesh availability and bone modifications in carcasses consumed 1539 by lions: palaeoecological relevance in hominid foraging patterns. Palaeogeography, 1540 Palaeoclimatology, Palaeoecology $149, \quad 373-388 . \quad$ https://doi.org/10.1016/S0031$1541 \quad 0182(98) 00213-2$ 
1542 Domínguez-Rodrigo, M., 2001. A study of carnivore competition in riparian and open habitats of 1543 modern savannas and its implications for hominid behavioral modeling. Journal of Human 1544 Evolution 40, 77-98. https://doi.org/10.1006/jhev.2000.0441

1545 Domínguez-Rodrigo, M., 2002. Hunting and scavenging by early humans: the state of the debate. 1546 Journal of World Prehistory 16, 1-54. https://doi.org/10.1023/A:1014507129795

1547 Domínguez-Rodrigo, M., 2009. Are all Oldowan sites palimpsests? If so, what can they tell us 1548 about hominid carnivory? In: Hovers, E., Braun, D.R. (Eds.), Interdisciplinary Approaches to 1549 the Oldowan. Springer Netherlands, Dordrecht, pp. 129-147. https://doi.org/10.1007/978-11550 4020-9060-8_11

1551 Domínguez- Rodrigo, M., Alcalá, L., 2016.3.3-Million-Year-Old stone tools and butchery traces? 1552 More evidence needed. PaleoAnthropology 2016, 46-53. 1553 https://doi.org/10.4207/PA.2016.ART99

1555 Domínguez-Rodrigo, M., Barba, R., 2006. New estimates of tooth mark and percussion mark 1556 frequencies at the FLK Zinj site: the carnivore-hominid-carnivore hypothesis falsified. Journal 1557 of Human Evolution 50, 170-194. https://doi.org/10.1016/j.jhevol.2005.09.005

1558 Domínguez-Rodrigo, M., Barba, R., Egeland, C.P., 2007. Deconstructing Olduvai: A Taphonomic 1559 Study of the Bed I Sites. Springer-Verlag, New York. https://doi.org/10.1007/978-1-4020$1560 \quad 6152-3$

1561 Domínguez-Rodrigo, M., Bunn, H.T., Mabulla, A.Z.P., Ashley, G.M., Diez-Martin, F., Barboni, 1562 D., Prendergast, M.E., Yravedra, J., Barba, R., Sánchez, A., Baquedano, E., Pickering, T.R., 1563 2010. New excavations at the FLK Zinjanthropus site and its surrounding landscape and their 
1564 behavioral implications. Quaternary Research 74, 315-332.

1565 https://doi.org/10.1016/j.yqres.2010.07.003

1566 Domínguez-Rodrigo, M., Cobo-Sánchez, L., 2017. A spatial analysis of stone tools and fossil 1567 bones at FLK Zinj 22 and PTK I (Bed I, Olduvai Gorge, Tanzania) and its bearing on the social 1568 organization of early humans. Palaeogeography, Palaeoclimatology, Palaeoecology 488, $21-$ 1569 34. https://doi.org/10.1016/j.palaeo.2017.04.010

1570 Domínguez-Rodrigo, M., Cobo-Sánchez, L., Aramendi, J., Gidna, A., 2019a. The meta-group 1571 social network of early humans: A temporal-spatial assessment of group size at FLK Zinj 1572 (Olduvai Gorge, Tanzania). Journal of Human Evolution 127, 54-66. 1573 https://doi.org/10.1016/j.jhevol.2018.11.001

1574 Domínguez-Rodrigo, M., Pickering, T.R., 2017. The meat of the matter: an evolutionary 1575 perspective on human carnivory. Azania: Archaeological Research in Africa 52, 4-32. $1576 \quad$ https://doi.org/10.1080/0067270X.2016.1252066

1577 Domínguez-Rodrigo, M., Pickering, T.R., Semaw, S., Rogers, M.J., 2005. Cutmarked bones from 1578 Pliocene archaeological sites at Gona, Afar, Ethiopia: implications for the function of the 1579 world's oldest stone tools. Journal of Human Evolution 48, 109-121. 1580 https://doi.org/10.1016/j.jhevol.2004.09.004

1581 Domínguez-Rodrigo, M., Sánchez-Flores, A.J., Baquedano, E., Carmen Arriaza, M., Aramendi, 1582 J., Cobo-Sánchez, L., Organista, E., Barba, R., 2019b. Constraining time and ecology on the 1583 Zinj paleolandscape: Microwear and mesowear analyses of the archaeofaunal remains of FLK 1584 Zinj and DS (Bed I), compared to FLK North (Bed I) and BK (Bed II) at Olduvai Gorge 1585 (Tanzania). Quaternary International 526, 4-14. https://doi.org/10.1016/j.quaint.2019.05.041 
1586 Domínguez-Rodrigo, M., Serrallonga, J., Luque, L., Diez-Martín, F., Alcalá, L., Bushozi, P., 2009.

1587 The Acheulian sites from the south escarpment. In: Domínguez-Rodrigo, M., Alcalá, L., Luque,

1588 L. (Eds.), Peninj: A Research Project on Human Origins 1995-2005. Oxbow Books (American

1589 School of Prehistoric Research), Cambridge, pp. 205-226.

1590 Du, H., Fu, J., Wang, S., Liu, H., Zeng, Y., Yang, J., Xiong, S., 2018. 1 H-NMR metabolomics 1591 analysis of nutritional components from two kinds of freshwater fish brain extracts. RSC 1592 Advances 8, 19470-19478. https://doi.org/10.1039/C8RA02311E

1593 Dublin, H.T., Ogutu, J.O., 2015. Population regulation of African buffalo in the Mara-Serengeti 1594 ecosystem. Wildlife Research 42, 382-393. https://doi.org/10.1071/WR14205

1595 Dufour, D.L., 1987. Insects as food: A case study from the Northwest Amazon. American 1596 Anthropologist 89, 383-397. https://doi.org/10.1525/aa.1987.89.2.02a00070

1597 Eaton, S. B., Easton III, S.B., Konner, M.J., 1997. Paleolithic nutrition revisited: A twelve-year 1598 retrospective on its nature and implications. European Journal of Clinical Nutrition 51, 2011599216.

1600 Egeland, C.P., Domínguez-Rodrigo, M., Barba, R., 2007. The Hunting-versus-scavenging 1601 debate. In: Domínguez-Rodrigo, M., Barba, R., Egeland, C.P. (Eds.), Deconstructing Olduvai: 1602 A Taphonomic Study of the Bed I Sites. Springer, Dordrecht, pp. 11-22. 1603 https://doi.org/10.1007/978-1-4020-6152-3_2

1604 Egeland, C.P., 2014. Taphonomic estimates of competition and the role of carnivore avoidance 1605 in hominin site use within the Early Pleistocene Olduvai basin. Quaternary International 322$1606 \quad 323,95-106$. https://doi.org/10.1016/j.quaint.2013.11.021

1607 Estes, R.D., 2004. The Behavior Guide to African Mammals: Including Hoofed Mammals, 1608 Carnivores, Primates (4th ed.). University of California Press, Berkeley. 
1609 Ewer, R.F., 1973. The Carnivores. Cornell University Press, Ithaca.

1610 Faith, J.T., Domínguez-Rodrigo, M., Gordon, A.D., 2009. Long-distance carcass transport at 1611 Olduvai Gorge? A quantitative examination of Bed I skeletal element abundances. Journal of 1612 Human Evolution 56, 247-256. https://doi.org/10.1016/j.jhevol.2008.12.008

1613 Ferraro, J.V., 2007. Broken Bones and Shattered Stones: On the Foraging Ecology of Oldowan 1614 Hominins. Ph.D. Dissertation, University of California.

1615 Ferraro, J.V., Plummer, T.W., Pobiner, B.L., Oliver, J.S., Bishop, L.C., Braun, D.R., Ditchfield, 1616 P.W., Seaman III, J.W., Binetti, K.M., Seaman Jr., J.W., Hertel, F., Potts, R., 2013. Earliest 1617 archaeological evidence of persistent hominin carnivory. PLoS ONE 8, e62174. 1618 https://doi.org/10.1371/journal.pone.0062174

1619 FitzGibbon, C.D., 1993. Antipredator strategies of female Thomson's gazelles with hidden fawns. 1620 Journal of Mammalogy 74, 758-762. https://doi.org/10.2307/1382299

1621 Fleming, T.H., Breitwisch, R., Whitesides, G.H., 1987. Patterns of tropical vertebrate frugivore 1622 diversity. Annual Review of Ecology and Systematics 18, 91-109. 1623 https://doi.org/10.1146/annurev.es.18.110187.000515

1624 Foley, R.A., 1983. Modelling hunting strategies and inferring predator behaviour from prey 1625 attributes. In: Clutton-Brock, J., Grigson C. (Eds.), Animals and Archaeology: 1. Hunters and 1626 their Prey. BAR International Series 163, Oxford, pp. 63-75.

1627 Foley, R.A., 1985. Optimality theory in anthropology. Man 20, 222-242.

1628 Foley, R.A., 1993. The influence of seasonality on hominid evolution. In: Ulijaszek, S.J., 1629 Strickland S. (Eds.), Seasonality and Human Ecology. Cambridge University Press, Cambridge, 1630 pp. 17-37. 
1631 Foley, R.A., 2001. The evolutionary consequences of increased carnivory in hominids. In: 1632 Stanford, C.B., Bunn, H.T. (Eds.), Meat-Eating and Human Evolution. Oxford University Press, $1633 \quad$ New York, pp. 305-331.

1634 Foley, R.A., Lee, P.C., 1991. Ecology and energetics of encephalization in hominid evolution. 1635 Philosophical Transactions of the Royal Society of London Series B: Biological Sciences 334, $1636 \quad 223-232$. https://doi.org/10.1098/rstb.1991.0111

1637 Funston, P., Mills, M., 2006. The influence of lion predation on the population dynamics of 1638 common large ungulates in the Kruger National Park. South African Journal of Wildlife 1639 Research 36, 9-22. https://doi.org/10.10520/EJC117232

1640 Gallotti, R., 2018. Before the Acheulean in East Africa: An overview of the Oldowan lithic 1641 assemblages. In: Gallotti, R., Mussi, M. (Eds.), The Emergence of the Acheulean in East Africa 1642 and Beyond: Contributions in Honor of Jean Chavaillon. Springer, Cham, pp. 13-32. 1643 https://doi.org/10.1007/978-3-319-75985-2_2

1644 Gagnon, M., Chew, A.E., 2000. Dietary preferences in extant African bovidae. Journal of 1645 1646

1647 Gao, X., Liu, J.-H., Ruan, Q.-J., Ge, J., Huang, Y., Liu, J., Li, Shufeng, Guan, Y., Shen, H., Wang, 1648 Y., Stidham, T., Deng, C., Li, Shenghua, Han, F., Li, B., Dennell, R., 2021. 300,000-year-old 1649 wooden tools from Gantangqing, southwest China. ResearchSquare. 1650 https://doi.org/10.21203/rs.3.rs-226285/v1

1651 Gathogo, P.N., Brown, F.H., 2006. Stratigraphy of the Koobi Fora Formation (Pliocene and 1652 Pleistocene) in the Ileret region of northern Kenya. Journal of African Earth Sciences. 45, 3691653 390. https://doi.org/10.1016/j.jafrearsci.2006.03.006 
1654 Gidna, A.O., Kisui, B., Mabulla, A., Musiba, C., Domínguez-Rodrigo, M., 2014. An ecological 1655 neo-taphonomic study of carcass consumption by lions in Tarangire National Park (Tanzania) 1656 and its relevance for human evolutionary biology. Quaternary International 322-323, 1671657 180. https://doi.org/10.1016/j.quaint.2013.08.059

1658 Gilby, I.C., Wawrzyniak, D., 2018. Meat eating by wild chimpanzees (Pan troglodytes 1659 schweinfurthii): Effects of prey age on carcass consumption sequence. International Journal of 1660 Primatology 39, 127-140. https://doi.org/10.1007/s10764-018-0019-9

1661 Gómez, A., Petrzelkova, K.J., Burns, M.B., Yeoman, C.J., Amato, K.R., Vlckova, K., Modry, D., 1662 Todd, A., Jost Robinson, C.A., Remis, M.J., Torralba, M.G., Morton, E., Umaña, J.D., 1663 Carbonero, F., Gaskins, H.R., Nelson, K.E., Wilson, B.A., Stumpf, R.M., White, B.A., Leigh, 1664 S.R., Blekhman, R., 2016. Gut microbiome of coexisting BaAka Pygmies and Bantu reflects 1665 gradients of traditional subsistence patterns. Cell Reports 14, 2142-2153. 1666 https://doi.org/10.1016/j.celrep.2016.02.013

1667 Goodall, J., 1971. In the Shadow of Man. Houghton Mifflin, Boston.

1668 Goodall, J., 1986. The Chimpanzees of Gombe: Patterns of Behavior. Harvard University Press, 1669 Cambridge (MA).

1670 Greenwood, P.H., 1955. Reproduction in the cat-fish, Clarias mossambicus Peters. Nature 176, $1671 \quad 516-518$. https://doi.org/10.1038/176516b0

1672 Greenwood, P.H., Todd, E.J., 1970. Fish remains from Olduvai. In: Leakey, L.S.B., Savage, R.J.G. 1673 (Eds.), Fossil Vertebrates of Africa, Volume 2. Academic Press, London, pp. 225-241.

1674 Gürbüz, R.B., Lycett, S.J., 2021. Could woodworking have driven lithic tool selection? Journal of 1675 Human Evolution 156, 102999. https://doi.org/10.1016/j.jhevol.2021.102999 
1676 Hamilton III, W.J., Tilson, R.L., 1985. Fishing baboons at desert waterholes. American Journal of 1677 Primatology 8, 255-257. https://doi.org/10.1002/ajp.1350080308

1678 Hart, T.B., Hart, J.A., 1986. The ecological basis of hunter-gatherer subsistence in African rain 1679 forests: The Mbuti of eastern Zaire. Human Ecology 14, 29-55. 1680 https://doi.org/10.1007/BF00889209

1681 Hawkes, K., 2000. Hunting and the evolution of egalitarian societies: lessons from the Hadza. In: 1682 Diehl, M.W. (Ed.), Hierarchies in Action: Cui Bono? Center for Archaeological Investigation, 1683 Southern Illinois University, Carbondale, pp. 59-83.

1684 Hawkes, K., 2016. Ethnoarchaeology and Plio-Pleistocene sites: Some lessons from the Hadza. 1685 Journal of Anthropological Archaeology 44, 158-165. 1686 https://doi.org/10.1016/j.jaa.2016.07.005

1687 Hawkes, K., Finlay, B.L., 2018. Mammalian brain development and our grandmothering life 1688 history. Physiology \& Behavior 193, 55-68. https://doi.org/10.1016/j.physbeh.2018.01.013

1689 Hawkes, K., Hill, K., O’Connell, J.F., 1982. Why hunters gather: Optimal foraging and the Ache 1690 of Eastern Paraguay. American Ethnologist 9, 379-398. 1691 https://doi.org/10.1525/ae.1982.9.2.02a00100

1692 Hawkes, K., O'Connell, J.F., 1992. On optimal foraging models and subsistence transitions. 1693 Current Anthropology 33, 63-66. https://doi.org/10.1086/204035

1694 Hawkes, K., O'Connell, J.F., Blurton Jones, N.G., 1989. Hardworking Hadza grandmothers. In: 1695 Standen, V., Foley R.A. (Eds.), Comparative Socioecology: The Behavioural Ecology of 1696 Humans and Other Mammals. Blackwell Scientific, Oxford, pp. 341-366.

1697 Hawkes, K., O’Connell, J.F., Blurton Jones., N.G., 1991. Hunting income patterns among the 1698 Hadza: big game, common goods, foraging goals, and the evolution of the human diet. 
Philosophical Transactions of the Royal Society B: Biological Sciences 334, 243-251. https://doi.org/10.1098/rstb.1991.0113

1701 Hawkes, K., O'Connell, J.F., Blurton Jones, N.G., 1995. Hadza children's foraging: juvenile 1702 dependency, social arrangements, and mobility among hunter-gatherers. Current Anthropology $1703 \quad 36,688-700$. https://doi.org/10.1086/204420

1704 Hawkes, K., O'Connell, J.F., Blurton Jones, N.G., 1997. Hadza women's time allocation, offspring 1705 provisioning, and the evolution of post-menopausal life spans. Current Anthropology 38, 5511706 578. https://doi.org/10.1086/204646

1707 Hawkes, K., O'Connell, J.F., Blurton Jones, N.G., 2018. Hunter-gatherer studies and human 1708 evolution: a very selective review. American Journal of Physical Anthropology 165, 777-800. 1709 https://doi.org/10.1002/ajpa.23403

1710 Hayden, B., 1981. Subsistence and ecological adaptations of modern hunter/gatherers. In: Harding, 1711 R.S.O., Teleki, G. (Eds.), Omnivorous Primates: Gathering and Hunting in Human Evolution. 1712 Columbia University Press, New York, pp. 344-421.

1713 Herbert, H.J., 1972. The population dynamics of the waterbuck Kobus ellipsiprymnus (Ogilby, 1714 1833) in the Sabi-Sand wildtuin. Mammalia Depicta. Verlag Paul Parey, Berlin.

1715 Herbert, T.D., Peterson, L.C., Lawrence, K.T., Liu, Z., 2010. Tropical ocean temperatures over the 1716 past 3.5 Million years. Science 328, 1530-1534. https://doi.org/10.1126/science.1185435

1717 Hernandez-Aguilar, R.A., Moore, J., Pickering, T.R., 2007. Savanna chimpanzees use tools to 1718 harvest the underground storage organs of plants. Proceedings of the National Academy of 1719 Sciences USA 104, 19210-19213. https://doi.org/10.1073/pnas.0707929104

1720 Hicks, T.C, Kühl, H.S, Boesch, C., Dieguez, P., Ayimisin, A.E, Fernandez, R.M, Zungawa, D.B, 1721 Kambere, M., Swinkels, J., Menken, S.B.J., Hart, J., Mundry, R., Roessingh, P., 2019. Bili- 
1722 Uéré: A chimpanzee behavioural realm in northern Democratic Republic of Congo. Folia 1723 Primatologica 90, 3-64. https://doi.org/10.1159/000492998

1724 Hill, K., Hawkes, K., Hurtado, M., Kaplan, H., 1984. Seasonal variance in the diet of Ache hunter1725 gatherers in Eastern Paraguay. Human Ecology 12, 101-135. 1726 https://doi.org/10.1007/BF01531269

1727 Hitchcock, R.K., 1989. Settlement, seasonality, and subsistence stress among the Tyua of northern 1728 Botswana. In: Huss-Ashmore, R., Curry, J.J., Hitchcock, R.K. (Eds.), Coping with Seasonal 1729 Constraints. MASCA Research Papers in Science and Archaeology, 5. University Museum, 1730 University of Pennsylvania, Philadelphia, pp. 64-85.

1731 Hitchcock, R.K., Yellen, J.E., Gelburd, D.J., Osborn, A.J., Crowell, A.L., 1996. Subsistence 1732 hunting and resource management among the Ju/'Hoansi of northwestern Botswana. African 1733 Study Monographs 17, 153-220. https://doi.org/10.14989/68150

1734 Hopcraft, J.G.C., Sinclair, A.R.E., Packer, C., 2005. Planning for success: Serengeti lions seek 1735 prey accessibility rather than abundance. Journal of Animal Ecology 74, 559-566. $1736 \quad$ https://doi.org/10.1111/j.1365-2656.2005.00955.x

1737 Hosfield, R., 2020. The earliest Europeans - a year in the life: seasonal survival strategies in the 1738 Lower Palaeolithic. Oxbow Books, Oxford.

1739 Hurtado, A.M., Hill, K.R., 1990. Seasonality in a foraging society: Variation in diet, work effort, 1740 fertility, and sexual division of labor among the Hiwi of Venezuela. Journal of Anthropological 1741 Research 46, 293-346. https://doi.org/10.1086/jar.46.3.3630428

1742 Ichikawa, M., 1983. An examination of the hunting-dependent life of the Mbuti Pygmies. African 1743 Study Monographs 4, 55-76. https://doi.org/10.14989/68001 
1744 Ims, R.A., 1990. On the adaptive value of reproductive synchrony as a predator-swamping 1745 strategy. American Naturalist 136, 485-498. https://doi.org/10.1086/285109

1746 Ingram, V., Ewane, M., Njie Ndumbe, L., Awono, A., 2017. Challenges to governing sustainable 1747 forest food: Irvingia spp. from southern Cameroon. Forest Policy and Economics 84, 29-37. $1748 \quad$ https://doi.org/10.1016/j.forpol.2016.12.014

1749 Isaac, G.L., 1978. The food-sharing behavior of protohuman hominids. Scientific American 238, 1750 90-108. https://doi.org/10.1038/scientificamerican0478-90

1751 Isaac, G.L., 1984. The archaeology of human origins. Advances in World Archaeology 3, 1-87.

1752 Isaac, G.L. 1986. Foundation stones: early artifacts as indicators of activities and abilities. In:

1753 Bailey, G.N., Callow, P. (Eds.), Stone Age Prehistory. Cambridge University Press, Cambridge, 1754 pp. 221-241.

1755 Jarman, P.J., 1974. The social organization of antelope in relation to their ecology. Behaviour 48, 1756 215-266. https://doi.org/10.1163/156853974X00345

1757 Jayathilakan, K., Sultana, K., Radhakrishna, K., Bawa, A.S., 2012. Utilization of byproducts and 1758 waste materials from meat, poultry and fish processing industries: a review. Journal of Food 1759 Science and Technology 49, 278-293. https://doi.org/10.1007/s13197-011-0290-7

1760 Jerardino, A., Marean, C.W., 2010. Shellfish gathering, marine paleoecology and modern human 1761 behavior: Perspectives from Cave PP13B, Pinnacle Point, South Africa. Journal of Human 1762 Evolution 59, 412-424. https://doi.org/10.1016/j.jhevol.2010.07.003

1763 Joannes-Boyau, R., Adams, J.W., Austin, C., Arora, M., Moffat, I., Herries, A.I.R., Tonge, M.P., 1764 Benazzi, S., Evans, A.R., Kullmer, O., Wroe, S., Dosseto, A., Fiorenza, L., 2019. Elemental 1765 signatures of Australopithecus africanus teeth reveal seasonal dietary stress. Nature 572, 112 1766 115. https://doi.org/10.1038/s41586-019-1370-5 
1767 Jones, P.R., 1981. Experimental implement manufacture and use: A case study from Olduvai 1768 Gorge, Tanzania. Philosophical Transactions of the Royal Society of London Series B: 1769 Biological Sciences 292, 189-195. https://doi.org/10.1098/rstb.1981.0027

1770 Jones, P.R., 1994. Results of experimental work in relation to the stone industries of Olduvai 1771 Gorge. In: Leakey M.D., Roe D.A. (Eds.), Olduvai Gorge: Volume 5. Excavations in Beds III, 1772 IV, and the Masek Beds. Cambridge University Press, Cambridge, pp. 254-298.

1773 Joordens, J.C.A., Feibel, C.S., Vonhof, H.B., Schulp, A.S., Kroon, D., 2019. Relevance of the 1774 eastern African coastal forest for early hominin biogeography. Journal of Human Evolution 1775 131, 176-202. https://doi.org/10.1016/j.jhevol.2019.03.012

1776 Joordens, J.C.A., Kuipers, R.S., Wanink, J.H., Muskiet, F.A.J., 2014. A fish is not a fish: Patterns 1777 in fatty acid composition of aquatic food may have had implications for hominin evolution. 1778 Journal of Human Evolution 77, 107-116. https://doi.org/10.1016/j.jhevol.2014.04.004

1779 Jubb, R.A., 1967. Freshwater fishes of southern Africa. Balkema, Capetown.

1780 Kaplan, H., Hill, K., 1985. Food sharing among Ache foragers: tests of explanatory hypotheses. 1781 Current Anthropology 26, 223-246. https://doi.org/10.1086/203251

1782 Karanth, K.U., Sunquist, M.E., 1995. Prey selection by tiger, leopard and dhole in tropical forests. 1783 Journal of Animal Ecology 64, 439-450. https://doi.org/10.2307/5647

1784 Kassa, B., Libois, R., Sinsin, B., 2007. Diet and food preference of the waterbuck (Kobus 1785 ellipsiprymnus defassa) in the Pendjari National Park, Benin. African Journal of Ecology 46, $1786 \quad 303-310$. https://doi.org/10.1111/j.1365-2028.2007.00827.x

1787 Kelly, R.L., 2013. The Lifeways of Hunter-Gatherers: The Foraging Spectrum (2nd ed.). 1788 Cambridge University Press, Cambridge. https://doi.org/10.1017/CBO9781139176132 
1789 Key, A., Proffitt, T., de la Torre, I., 2020. Raw material optimization and stone tool engineering 1790 in the Early Stone Age of Olduvai Gorge (Tanzania). Journal of The Royal Society Interface 17, 20190377. https://doi.org/10.1098/rsif.2019.0377

1792 Kingdon, J., 2015. The Kingdon Field Guide to African Mammals (2nd ed.). Bloomsbury, London. 1793 Kingdon, J., Hoffman, M., 2013. Mammals of Africa (Volume VI): Hippopotamuses, Pigs, Deer, 1794 Giraffe and Bovids. Bloomsbury, London.

1795 Kitanishi, K., 1994. The exchange of forest products (lrvingia nuts) between the Aka hunter 1796 gatherers and the cultivators in Northeastern Congo. Tropics 4, 79-92. $1797 \quad$ https://doi.org/10.3759/tropics.4.79

1798 Kitanishi, K., 1995. Seasonal changes in the subsistence activities and food intake of the Aka 1799 hunter-gatherers in northeastern Congo. African Study Monographs 16, 73-118. 1800 https://doi.org/10.14989/68133

1801 Kofron, C.P., 1993. Behavior of Nile crocodiles in a seasonal river in Zimbabwe. Copeia 2, $463-$ 1802 469. https://doi.org/10.2307/1447146

1803 Kruuk, H., 1976. The Spotted Hyena: A Study of Predation and Social Behaviour. University of 1804 Chicago Press, Chicago.

1805 Kuipers, R., Luxwolda, M., Janneke Dijck-Brouwer, D., Eaton, S., Crawford, M., Cordain, L., 1806 Muskiet, F., 2010. Estimated macronutrient and fatty acid intakes from an East African 1807 Paleolithic diet. British Journal of Nutrition 104(11), 1666-1687. $1808 \quad$ https://doi.org/10.1017/S0007114510002679

1809 Kummer, H., Goodall, J. 1985. Conditions of innovative behaviour in primates. Philosophical 1810 Transactions of the Royal Society of London Series B: Biological Sciences 308, 203-214. 1811 https://doi.org/10.1098/rstb.1985.0020 
1812 Kurland, J.A., Beckerman, S.J., 1985. Optimal foraging and hominid evolution: labor and

1813 reciprocity. American Anthropologist 87, 73-93.

1814 https://doi.org/10.1525/aa.1985.87.1.02a00070

1815 Kyriacou, K., Blackhurst, D.M., Parkington, J.E., Marais A.D., 2016. Marine and terrestrial

1816 foods as a source of brain-selective nutrients for early Modern Humans in the southwestern

1817 Cape, South Africa. Journal of Human Evolution 97, 86-96.

1818 https://doi.org/10.1016/j.jhevol.2016.04.009

1819 Laden, G., Wrangham, R. 2005. The rise of the hominids as an adaptive shift in fallback foods:

1820 plant underground storage organs (USOs) and australopith origins. Journal of Human Evolution

$1821 \quad 49,482-498$. https://doi.org/10.1016/j.jhevol.2005.05.007

1822 Lam, Y.M., 2008. What have taphonomic studies taught us about early hominin behavior?

1823 Evolutionary Anthropology 17, 158-161. https://doi.org/10.1002/evan.20175

1824 Lambert, J.E., 2007. Seasonality, fallback strategies, and natural selection: a chimpanzee and

1825 Cercopithecoid model for interpreting the evolution of the hominin diet. In: Ungar, P.S. (Ed.),

1826 Evolution of the human diet: the known, the unknown, and the unknowable. Oxford University

1827 Press, Oxford, pp. 324-343.

1828 Leakey, M.D., 1971. Olduvai Gorge: Volume 3, Excavations in Beds I and II, 1960-1963.

1829 Cambridge University Press, Cambridge.

1830 Lee, R.B., 2013. The Dobe Ju/'hoansi (4th Ed.). Wadsworth, Belmont (CA).

1831 Lee, R.B., DeVore, I. 1968. Man the Hunter. Based on a symposium, Chicago, 1966. Aldine, 1832 Chicago.

1833 Lemorini, C., Bishop, L.C., Plummer, T.W., Braun, D.R., Ditchfield, P.W., Oliver, J.S., 2019. Old 1834 stones' song - second verse: use-wear analysis of rhyolite and fenetized andesite artifacts from 
1835 the Oldowan lithic industry of Kanjera South, Kenya. Archaeological and Anthropological 1836 Sciences 11, 4729-4754. https://doi.org/10.1007/s12520-019-00800-z

1837 Lemorini, C., Plummer, T.W., Braun, D.R., Crittenden, A.N., Ditchfield, P.W., Bishop, L.C., 1838 Hertel, F., Oliver, J.S., Marlowe, F.W., Schoeninger, M.J., Potts, R., 2014. Old stones' song: 1839 Use-wear experiments and analysis of the Oldowan quartz and quartzite assemblage from 1840 Kanjera South (Kenya). Journal of Human Evolution 72, 10-25. $1841 \quad$ https://doi.org/10.1016/j.jhevol.2014.03.002

1842 Lent, P.C., 1974. Mother-infant relationships in ungulates. In Geist, V., Walther, F. (Eds.), The 1843 Behaviour of Ungulates and Its Relation to Management. International Union for Conservation 1844 and Natural Resources Publications, Morges, pp. 14-55.

1845 Lesnik, J.J., 2014. Termites in the hominin diet: A meta-analysis of termite genera, species and 1846 castes as a dietary supplement for South African robust australopithecines. Journal of Human 1847 Evolution 71, 94-104. https://doi.org/10.1016/j.jhevol.2013.07.015

1848 Liebenberg, L., 2006. Persistence hunting by modern hunter-gatherers. Current Anthropology 47, 1849 1017-1026. https://doi.org/10.1086/508695

1850 Lisiecki, L.E., Raymo, M.E., 2005. A Pliocene-Pleistocene stack of 57 globally distributed benthic $1851 \quad \delta^{18} \mathrm{O}$ records. Paleoceanography and Paleoclimatology 20(1), PA1003. 1852 https://doi.org/10.1029/2004PA001071

1853 Lombard, M., Kyriacou, K., 2018. Hunter-Gatherer Women. In: Oxford Research Encyclopedia 1854 of Anthropology. Oxford University 1855 https://doi.org/10.1093/acrefore/9780190854584.013.105 
1856 Lupo, K., 2001. Archaeological skeletal part profiles and differential transport: an

1857 ethnoarchaeological example from Hadza bone assemblages. Journal of Anthropological

1858 Archaeology 20, 361-378. https://doi.org/10.1006/jaar.2000.0378

1859 Lupo, K.D., 2006. What explains the carcass field processing and transport decisions of 1860 contemporary hunter-gatherers? Measures of Economic Anatomy and Zooarchaeological 1861 Skeletal Part Representation. Journal of Archaeological Method and Theory 13, 19-66. 1862 https://doi.org/10.1007/s10816-006-9000-6

1863 Magill, C.R., Ashley, G.M., Domínguez-Rodrigo, M., Freeman, K.H., 2016. Dietary options and 1864 behavior suggested by plant biomarker evidence in an early human habitat. Proceedings of the 1865

1867 Marean, C.W., Spencer, L.M., Blumenschine, R.J., Capaldo, S.D., 1992. Captive hyaena bone 1868 choice and destruction, the schlepp effect and Olduvai archaeofaunas. Journal of 1869 Archaeological Science 19, 101-121. https://doi.org/10.1016/0305-4403(92)90009-R

1870 Marlowe, F.W., Berbesque, J.C., 2009. Tubers as fallback foods and their impact on Hadza hunter1871 gatherers. American Journal of Physical Anthropology 140, 751-758. 1872 https://doi.org/10.1002/ajpa.21040

1873 Marlowe, F.W., Berbesque, J.C., Wood, B., Crittenden, A., Porter, C., Mabulla, A., 2014. Honey, 1874 Hadza, hunter-gatherers, and human evolution. Journal of Human Evolution 71, 119-128. 1875 https://doi.org/10.1016/j.jhevol.2014.03.006

1876 Marshall, A.J., Boyko, C.M., Fellen, K.M., Boyko, R.H., Leighton, M., 2009. Defining fallback 1877 foods and assessing their importance in primate ecology and evolution. American Journal of 1878 Physical Anthropology 140, 603-614. https:/doi.org/10.1002/ajpa.21082 
1879 Marshall, A.J., Wrangham, R.W., 2007. Evolutionary consequences of fallback foods. 1880 International Journal of Primatology 28, 1219-1235. https://doi.org/10.1007/s10764-007-9218$1881 \quad 5$

1882 Mattisson, J., Rauset, G.R., Odden, J., Andrén, H., Linnell, J.D.C., Persson, J., 2016. Predation or 1883 scavenging? Prey body condition influences decision-making in a facultative predator, the 1884 wolverine. Ecosphere 7, e01407. https://doi.org/10.1002/ecs2.1407

1885 McGrew, W.C., Ham, R.M., White, L.J.T., Tutin, C.E.G., Fernandez, M., 1997. Why don’t 1886 chimpanzees in Gabon crack nuts? International Journal of Primatology 18, 353-374. 1887 https://doi.org/10.1023/A:1026382316131

1888 McGrew, W.C., Tutin, C.E.G., Baldwin, P.J., 1979. Chimpanzees, tools, and termites: cross1889 cultural comparisons of Senegal, Tanzania, and Rio Muni. Man 14, 185-214. 1890 https://doi.org/10.2307/2801563

1891 McPherron, S.P., Alemseged, Z., Marean, C.W., Wynn, J.G., Reed, D., Geraads, D., Bobe, R., 1892 Béarat, H.A., 2010. Evidence for stone-tool-assisted consumption of animal tissues before $1893 \quad 3.39$ million years ago at Dikika, Ethiopia. Nature 466, 857-860.

1894 https://doi.org/10.1038/nature09248

1895 McNaughton, S.J., Georgiadis, N.J., 1986. Ecology of African grazing and browsing mammals. 1896 Annual Review of Ecology and Systematics 17, 39-65.

1897 https://doi.org/10.1146/annurev.es.17.110186.000351

1898 Melin, A.D., Young, H.C., Mosdossy, K.N., Fedigan, L.M., 2014. Seasonality, extractive foraging 1899 and the evolution of primate sensorimotor intelligence. Journal of Human Evolution 71, 77-86. 1900 https://doi.org/10.1016/j.jhevol.2014.02.009 
1901 Metcalfe, D., Barlow, K.R., 1992. A model for exploring the optimal trade-off between field 1902 processing and transport. American Anthropologist 94, 340-356. 1903 https://doi.org/10.1525/aa.1992.94.2.02a00040

1904 Mitani, J.C, Watts, D.P., 2005. Seasonality in hunting by non-human primates. In: Brockman, 1905 D.K., van Schaik, C.P. (Eds.), Seasonality in Primates: Studies of Living and Extinct Human 1906 and Non-Human Primates. Cambridge University Press, Cambridge, pp. 215-241.

1907 Molinari-Jobin, A., Molinari, P., Loison, A., Gaillard, J.M., Breitenmoser, U., 2004. Life cycle 1908 period and activity of prey influence their susceptibility to predators. Ecography 27, 323-329. 1909 https://doi.org/10.1111/j.0906-7590.2004.03862.x

1910 Moore, J., Black, J., Hernandez-Aguilar, R.A., Idani, G., Piel, A., Stewart, F., 2017. Chimpanzee 1911 vertebrate consumption: savanna and forest chimpanzees compared. Journal of Human 1912 Evolution 112, 30-40. https://doi.org/10.1016/j.jhevol.2017.09.004

1913 Munro, H. N., 1964. General aspects of the regulation of protein metabolism by diet and by 1914 hormones. In: Munro, H.N. and Allison, J.B. (Eds), Mammalian Protein Metabolism (Vol. 1). 1915 Academic Press, New York, pp. 381-481.

1916 Murdock, G.K., Stine, W.W., Maple, T.L., 1983. Observations of maternal-infant interactions in a 1917 captive herd of sable antelope (Hippotragus niger). Zoo Biology 2, 215-224. 1918 https://doi.org/10.1002/zoo.1430020307

1919 Murray, M.G., 1982. The rut of impala: aspects of seasonal mating under tropical conditions. 1920 Zeitschrift für Tierpsychologie 59, 319-337. https://doi.org/10.1111/j.1439$1921 \quad$ 0310.1982.tb00345.x

1922 Navarrete, A.F., Reader, S.M., Street, S.E., Whalen, A., Laland, K.N., 2016. The coevolution of 1923 innovation and technical intelligence in primates. Philosophical Transactions of the Royal 
1924 Society of London Series B: Biological Sciences 371, 20150186. 1925 https://doi.org/10.1098/rstb.2015.0186

1926 Newlin, H.E., McCay, C.M., 1948. Bone marrow for fat storage in rabbits. Archives of 1927 Biochemistry 17, 125-128.

1928 Nilssen, P.J., 2000. An Actualistic Butchery Study in South Africa and Its Implications for 1929 Reconstructing Hominid Strategies of Carcass Acquisition and Butchery in the Upper 1930 Pleistocene and Plio-Pleistocene. Ph.D. dissertation. University of Cape Town.

1931 Njau, J.K., 2012. Crocodile Predation and Hominin Evolution: Landscape Paleoanthropology at 1932 Olduvai Gorge. LAP GmbH and Co. KG, Saarbrucken, Germany.

1933 Njau, J.K., Blumenschine, R.J., 2012. Crocodylian and mammalian carnivore feeding traces on 1934 hominin fossils from FLK 22 and FLK NN 3, Late Pliocene, Olduvai Gorge, Tanzania. Journal 1935 of Human Evolution 63, 408-417. https://doi.org/10.1016/j.jhevol.2011.05.008

1936 O’Connell, J.F., Hawkes, K., Jones, N.B., 1988a. Hadza hunting, butchering, and bone transport 1937 and their archaeological implications. Journal of Anthropological Research 44, 113-161.

1938 https://doi.org/10.1086/jar.44.2.3630053

1939 O’Connell, J.F., Hawkes, K., Blurton Jones, N.G., 1988b. Hadza scavenging: implications for Plio1940 Pleistocene subsistence. Current Anthropology 29, 356-363. https://doi.org/10.1086/203648

1941 O'Connell, J.F., Hawkes, K., Blurton-Jones, N. 1990. Reanalysis of large mammal body part 1942 transport among the Hadza. Journal of Archaeological Science 17, 301-16. 1943 https://doi.org/10.1016/0305-4403(90)90025-Z

1944 O'Connell, J.F., Hawkes, K., Blurton-Jones, N.G., 1992. Patterns in the distribution, site 1945 structure and assemblage composition of Hadza kill-butchering sites. Journal of 1946 Archaeological Science 19, 319-345. https://doi.org/10.1016/0305-4403(92)90020-4 
1947 O’Connell, J.F., Hawkes, K., Lupo, K.D., Blurton Jones, N.G., 2002. Male strategies and Plio1948 Pleistocene archaeology. Journal of Human Evolution 43, 831-872. 1949 https://doi.org/10.1006/jhev.2002.0604

1950 O'Dea, K., Jewell, P.A., Whiten, A., Altmann, S.A., Strickland, S.S., Oftedal, O.T., 1991. 1951 Traditional diet and food preferences of Australian Aboriginal hunter-gatherers. Philosophical 1952 Transactions of the Royal Society of London Series B: Biological Sciences 334, 233-241. 1953 https://doi.org/10.1098/rstb.1991.0112

1954 Oelze, V.M., Fuller, B.T., Richards, M.P., Fruth, B., Surbeck, M., Hublin, J.-J., Hohmann, G., 1955 2011. Exploring the contribution and significance of animal protein in the diet of bonobos by 1956 stable isotope ratio analysis of hair. Proceedings of the National Academy of Sciences USA 1957 108, 9792-9797. https://doi.org/10.1073/pnas.1018502108

1958 Oelze, V.M., Head, J.S., Robbins, M.M., Richards, M., Boesch, C., 2014. Niche differentiation 1959 and dietary seasonality among sympatric gorillas and chimpanzees in Loango National Park 1960 (Gabon) revealed by stable isotope analysis. Journal of Human Evolution 66, 95-106. $1961 \quad$ https://doi.org/10.1016/j.jhevol.2013.10.003

1962 Oliver, J.S., 1992. Carcass processing by the Hadza: bone breakage from butchery to consumption. 1963 In: Hudson, J. (Ed.), From Bones to Behavior: Ethnoarchaeological and Experimental 1964 Contributions to the Interpretation of Faunal Remains. Center for Archaeological 1965 Investigations, Southern Illinois University, Carbondale, pp. 200-227.

1966 Oliver, J.S., 1994. Estimates of hominid and carnivore involvement in the FLK Zinjanthropus 1967 fossil assemblage: some socioeconomic implications. Journal of Human Evolution 27, 2671968 294. https://doi.org/10.1006/jhev.1994.1046 
1969 Oliver, J.S., Plummer, T.W., Hertel, F., Bishop, L.C., 2019. Bovid mortality patterns from Kanjera 1970 South, Homa Peninsula, Kenya and FLK-Zinj, Olduvai Gorge, Tanzania: Evidence for habitat 1971 mediated variability in Oldowan hominin hunting and scavenging behavior. Journal of Human 1972 Evolution 131, 61-75. https://doi.org/10.1016/j.jhevol.2019.03.009

1973 Owen-Smith, N. 2008. Changing vulnerability to predation related to season and sex in an African 1974 ungulate assemblage. Oikos 117, 602-610. https://doi.org/10.1111/j.0030-1299.2008.16309.x 1975 Pante, M.C., Blumenschine, R.J., Capaldo, S.D., Scott, R.S., 2012. Validation of bone surface 1976 modification models for inferring fossil hominin and carnivore feeding interactions, with 1977 reapplication to FLK 22, Olduvai Gorge, Tanzania. Journal of Human Evolution 63(2), 395$1978 \quad$ 407. https://doi.org/10.1016/j.jhevol.2011.09.002

1979 Pante, M.C., Njau, J.K., Hensley-Marschand, B., Keevil, T.L., Martín-Ramos, C., Peters, R.F., de 1980 la Torre, I., 2018. The carnivorous feeding behavior of early Homo at HWK EE, Bed II, Olduvai 1981 Gorge, Tanzania. Journal of Human Evolution 120, 215-235. 1982 https://doi.org/10.1016/j.jhevol.2017.06.005

1983 Pante, M.C., Scott, R.S., Blumenschine, R.J., Capaldo, S.D., 2015. Revalidation of bone surface 1984 modification models for inferring fossil hominin and carnivore feeding interactions. Quaternary 1985 International 355, 164-168. https://doi.org/10.1016/j.quaint.2014.09.007

1986 Pape, R., Löffler, J., 2015. Seasonality of habitat selection shown to buffer alpine reindeer 1987 pastoralism against climate variability. Ecosphere 6(12), 260. http://dx.doi.org/10.1890/ES15$1988 \quad 00169.1$

1989 Parkinson, J.A., 2013. A GIS Image Analysis Approach to Documenting Oldowan Hominin 1990 Carcass Acquisition: Evidence from Kanjera South, FLK Zinj, and Neotaphonomic Models of 1991 Carnivore Bone Destruction. Ph.D. Dissertation, City University of New York. 
1992 Parkinson, J.A., 2018. Revisiting the hunting-versus-scavenging debate at FLK Zinj: A GIS spatial 1993 analysis of bone surface modifications produced by hominins and carnivores in the FLK 22 1994 assemblage, Olduvai Gorge, Tanzania. Palaeogeography, Palaeoclimatology, Palaeoecology 1995 511, 29-51. https://doi.org/10.1016/j.palaeo.2018.06.044

1996 Pascual-Garrido, A., Almeida-Warren, K., 2021. Archaeology of the perishable: ecological 1997 constraints and cultural variants in chimpanzee termite fishing. Current Anthropology 62, 333$1998 \quad 362$. https://doi.org/10.1086/713766

1999 Pennec, F., Gérard, C., Meterreau, L., Monghiemo, C., Bokika Ngawolo, J., Laurent, R., \& Narat, 2000 V., 2020. Spatiotemporal variation of bonobo (Pan paniscus) habitat use in a forest-savanna 2001 mosaic. International Journal of Primatology 41, 775-799. https://doi.org/10.1007/s10764-020$2002 \quad 00180-5$.

2003 Pereira, L.M., Owen-Smith, N., Moleón, M., 2014. Facultative predation and scavenging by 2004 mammalian carnivores: seasonal, regional and intra-guild comparisons. Mammal Review 44, 2005 44-55. https://doi.org/10.1111/mam.12005

2006 Plummer, T., 2004. Flaked stones and old bones: biological and cultural evolution at the dawn of 2007 technology. American Journal of Physical Anthropology 125, 118-164.

2008 Plummer, T.W., Bishop, L.C., 2016. Oldowan hominin behavior and ecology at Kanjera South, 2009 Kenya. Journal of Anthropological Sciences. 94, 1-12. https://doi.org/10.4436/JASS.94033

2010 Plummer, T.W., Bishop, L.C., Ditchfield, P., Hicks, J., 1999. Research on Late Pliocene Oldowan 2011 Sites at Kanjera South, Kenya. Journal of Human Evolution 36, 151-170. 2012 https://doi.org/10.1006/jhev.1998.0256 
2013 Plummer, T.W., Ditchfield, P.W., Bishop, L.C., Kingston, J.D., Ferraro, J.V., Braun, D.R., Hertel, 2014 F., Potts, R., 2009. Oldest evidence of toolmaking hominins in a grassland-dominated 2015 ecosystem. PLoS ONE 4, e7199. https://doi.org/10.1371/journal.pone.0007199

2016 Pobiner, B.L., 2015. New actualistic data on the ecology and energetics of hominin scavenging 2017 opportunities. Journal of Human Evolution 80, 1-16. 2018 https://doi.org/10.1016/j.jhevol.2014.06.020

2019 Pobiner, B.L., 2020. The zooarchaeology and paleoecology of early hominin scavenging. 2020 Evolutionary Anthropology 29, 68-82. https://doi.org/10.1002/evan.21824

2021 Potts, R., 1984. Home bases and early hominids. American Scientist 72, 338-347.

2022 Potts, R., 1988. Early Hominid Activities at Olduvai. Aldine, New York.

2023 Potts, R., 1991. Why the Oldowan? Plio-Pleistocene toolmaking and the transport of resources. 2024 Journal of Anthropological Research 47, 153-176. https://doi.org/10.1086/jar.47.2.3630323

2025 Potts, R., 2012. Environmental and behavioral evidence pertaining to the evolution of early Homo. 2026 Current Anthropology 53, S299-S317. https://doi.org/10.1086/667704

2027 Potts, R., Faith, J.T., 2015. Alternating high and low climate variability: The context of natural 2028 selection and speciation in Plio-Pleistocene hominin evolution. Journal of Human Evolution $2029 \quad$ 87, 5-20. https://doi.org/10.1016/j.jhevol.2015.06.014

2030 Potts, R., Shipman, P., 1981 Cutmarks made by stone tools on bones from Olduvai Gorge, 2031 Tanzania. Nature 291, 577-580. https://doi.org/10.1038/291577a0

2032 Pruetz, J.D., Bertolani, P., 2007. Savanna chimpanzees, Pan troglodytes verus, hunt with tools. 2033 Current Biology 17, 412-417. https://doi.org/10.1016/j.cub.2006.12.042

2034 Pruetz, J.D., Bertolani, P., Ontl, K.B., Lindshield, S., Shelley, M., Wessling, E.G., 2015. New 2035 evidence on the tool-assisted hunting exhibited by chimpanzees (Pan troglodytes verus) in a 
2036 savannah habitat at Fongoli, Sénégal. Royal Society Open Science 2, 140507. 2037 https://doi.org/10.1098/rsos.140507

2038 Ralls, K., Kranz, K., Lundrigan, B., 1986. Mother-young relationships in captive ungulates: 2039 variability and clustering. Animal Behaviour 34, 134-145. https://doi.org/10.1016/0003$2040 \quad 3472(86) 90015-1$

2041 Redfern, J.V., Grant, R., Biggs, H., Getz, W.M. 2003. Surface water constraints on herbivore 2042 foraging in the Kruger National Park, South Africa. Ecology 84, 2092-2107.

2043 https://doi.org/10.1890/01-0625

2044 Reeves, J. S., Braun, D. R., Finestone, E. M., Plummer, T. W. 2021. Ecological perspectives on 2045 technological diversity at Kanjera South. Journal of Human Evolution 158, 103029.

2046 https://doi.org/10.1016/j.jhevol.2021.103029

2047 Remis, M.J., 1997. Western Lowland gorillas (Gorilla gorilla gorilla) as seasonal frugivores: use 2048 of variable resources. American Journal of Primatology 43, 87-109. 2049 https://doi.org/10.1002/(SICI)1098-2345(1997)43:2<87::AID-AJP1>3.0.CO;2-T

2050 Remis, M.J., Jost Robinson, C.A., 2014. Examining Short-Term Nutritional Status Among BaAka 2051 Foragers in Transitional Economies. American Journal of Physical Anthropology 154, 365$2052 \quad 375$. https://doi.org/10.1002/ajpa.22521

2053 Richardson, D.P., Wayler, A.H., Scrimshaw, N.S., Young, V.R. 1979. Quantitative effect of an 2054 isoenergetic exchange of fat for carbohydrate on dietary protein utilization in healthy young 2055 men. American Journal of Clinical Nutrition 32, 2217-2226. 2056 https://doi.org/10.1093/ajen/32.11.2217 
2057 Riel-Salvatore, J., Barton, C.M. 2004. Late Pleistocene technology, economic behavior, and land2058 use dynamics in southern Italy. American Antiquity 69, 257-274. 2059 https://doi.org/10.2307/4128419

2060 Rivals, F., Uno, K.T., Bibi, F., Pante, M.C., Njau, J., de la Torre, I., 2018. Dietary traits of the 2061 ungulates from the HWK EE site at Olduvai Gorge (Tanzania): Diachronic changes and 2062 seasonality. Journal of Human Evolution 120, 203-214. 2063 https://doi.org/10.1016/j.jhevol.2017.08.011

2064 Russon, A.E., Compost, A., Kuncoro, P., Ferisa, A., 2014. Orangutan fish eating, primate aquatic 2065 fauna eating, and their implications for the origins of ancestral hominin fish eating. Journal of 2066 Human Evolution 77, 50-63. https://doi.org/10.1016/j.jhevol.2014.06.007

2067 Rutberg, A.T., 1987. Adaptive hypotheses of birth synchrony in ruminants: an interspecific test. 2068 American Naturalist 130, 692-710. https://doi.org/10.1086/284739

2069 Sahnouni, M., Parés, J.M., Duval, M., Cáceres, I., Harichane, Z., van der Made, J., Pérez2070 González, A., Abdessadok, S., Kandi, N., Derradji, A., Medig, M., Boulaghraif, K., Semaw, S., 2071 2018. 1.9-million- and 2.4-million-year-old artifacts and stone tool-cutmarked bones from Ain 2072 Boucherit, Algeria. Science 362, 1297-1301. https://doi.org/10.1126/science.aau0008

2073 Sampson, C.G., 2000. Taphonomy of tortoises deposited by birds and bushman. Journal of 2074 Archaeological Science 27, 779-782. https://doi.org/10.1006/jasc.1999.0500

2075 Sánchez-Yustos, P., Diez-Martín, F., Díaz, I.M., Duque, J., Fraile, C., Domínguez-Rodrigo, M., 2076 2015. Production and use of percussive stone tools in the Early Stone Age: Experimental 2077 approach to the lithic record of Olduvai Gorge, Tanzania. Journal of Archaeological Science: 2078 Reports 2, 367-383. https://doi.org/10.1016/j.jasrep.2015.03.005 
2079 Sato, H., Kawamura, K., Hayashi, K., Inai, H., Yamauchi, T., 2012. Addressing the wild yam 2080 question: how Baka hunter-gatherers acted and lived during two controlled foraging trips in the 2081 tropical rainforest of Southeastern Cameroon. Anthropological Science 120, 129-149. 2082 https://doi.org/10.1537/ase.110913

2083 Schaller, G.B., 1972. The Serengeti Lion: a Study of Predator Prey Relations. University of 2084 Chicago Press, Chicago.

2085 Schaller, G.B., Lowther, G.R., 1969. The relevance of carnivore behavior to the study of early 2086 hominids. Southwestern Journal of Anthropology 25, 307-341. 2087 https://doi.org/10.1086/soutjanth.25.4.3629426

2088 Schapera, I., 1930. The Khoisan peoples of South Africa: Bushmen and Hottentots. Routledge and 2089 Kegan Paul, London.

2090 Schoville, B.J., Otárola-Castillo, E., 2014. A model of hunter-gatherer skeletal element transport: 2091 the effect of prey body size, carriers, and distance. Journal of Human Evolution 73, 1-14. 2092 https://doi.org/10.1016/j.jhevol.2014.06.004

2093 Semaw, S., Renne, P., Harris, J.W.K., Feibel, C.S., Bernor, R.L., Fesseha, N., Mowbray, K., 1997. 2094 2.5-million-year-old stone tools from Gona, Ethiopia. Nature 385, 333-336. 2095 https://doi.org/10.1038/385333a0

2096 Semaw, S., Rogers, M.J., Quade, J., Renne, P.R., Butler, R.F., Dominguez-Rodrigo, M., Stout, D., 2097 Hart, W.S., Pickering, T., Simpson, S.W., 2003. 2.6-Million-year-old stone tools and associated 2098 bones from OGS-6 and OGS-7, Gona, Afar, Ethiopia. Journal of Human Evolution 45, 1692099 177. https://doi.org/10.1016/s0047-2484(03)00093-9 
2100 Sept, J.M., 1984. Plants and early hominids in East Africa: a study of vegetation in situations 2101 comparable to early archaeological site locations. Ph.D. Dissertation, Department of 2102 Anthropology, University of California.

2103 Shea, J.J., 2020. Prehistoric Stone Tools of Eastern Africa: A Guide. Cambridge University Press, 2104 Cambridge.

2105 Sherry, D.S., Marlowe, F.W., 2006. Anthropometric data indicate nutritional homogeneity in 2106 Hadza foragers of Tanzania. American Journal of Human Biology 19, 107-118. 2107 https://doi.org/10.1002/ajhb.20591

2108 Shipman, P., 1986. Scavenging or hunting in early hominids: Theoretical framework and tests. 2109 American Anthropologist 88, 27-43. https://doi.org/10.1525/aa.1986.88.1.02a00020

2110 Sinclair, A.R.E., 1975. The resource limitation of trophic levels in tropical grassland ecosystems. 2111 Journal of Animal Ecology 44, 497-520. https://doi.org/10.2307/3608

2112 Sinclair, A., Mduma, S., Brashares, J., 2003. Patterns of predation in a diverse predator-prey 2113 system. Nature 425, 288-290. https://doi.org/10.1038/nature01934

2114 Sinclair, A.R.E., Mduma, Simon A.R., Arcese, M., 2000. What determines phenology and 2115 synchrony of ungulate breeding in Serengeti? Ecology 81, 2100-2111. 2116 https://doi.org/10.1890/0012-9658(2000)081[2100:WDPASO]2.0.CO;2

2117 Son, V.D., 2003. Diet of Macaca fascicularis in a mangrove forest. Vietnam Laboratory Primate $2118 \quad$ News. 42, 1-5.

2119 Spencer, L.M., 1997. Dietary adaptations of Plio-Pleistocene Bovidae: implications for hominid 2120 habitat use. Journal of Human Evolution 32, 201-228. https://doi.org/10.1006/jhev.1996.0102 2121 Speth, J.D., 1983. Bison Kills and Bone Counts: Decision Making by Ancient Hunters. University 2122 of Chicago Press, Chicago. 
2123 Speth, J.D., 1987. Early hominid subsistence strategies in seasonal habitats. Journal of 2124 Archaeological Science 14, 13-29. https://doi.org/10.1016/S0305-4403(87)80003-1

2125 Speth, J.D., 1989. Early hominid hunting and scavenging: the role of meat as an energy source. 2126 Journal of Human Evolution 18, 329-343. https://doi.org/10.1016/0047-2484(89)90035-3

2127 Speth, J.D., 1990. Seasonality, resource stress, and food sharing in so-called "egalitarian" foraging 2128 societies. Journal of Anthropological Archaeology 9, 148-188. https://doi.org/10.1016/0278$2129 \quad 4165(90) 90002-U$

2130 Speth, J.D., Davis, D.D., 1976. Seasonal variability in early hominid predation. Science 192, 441$2131 \quad 445$. https://doi.org/10.1126/science.192.4238.441

2132 Speth, J.D., Spielmann, K., 1983. Energy source, protein metabolism and hunter-gatherer 2133 subsistence strategies. Journal of Anthropological Archaeology 2, 1-31. 2134 https://doi.org/10.1016/0278-4165(83)90006-5

2135 Speth, J.D., Widdowson, E.M., Oftedal, O.T., Foley, R.A., Van Soest, P., Widdowson, E.M., 2136 Whiten, A., Bone, Q., 1991. Protein selection and avoidance strategies of contemporary and 2137 ancestral foragers: unresolved issues. Philosophical Transactions of the Royal Society of 2138 London. Series B: Biological Sciences 334, 265-270. https://doi.org/10.1098/rstb.1991.0115

2139 Spinage, C.A., 1982. A Territorial Antelope: The Uganda Waterbuck. Academic Press, London.

2140 Spinage, C.A., 1984. Seasonal influences and the kidney fat index in two equatorial African 2141 ungulates. African Journal of Ecology 22, 17-22. https://doi.org/10.1111/j.1365$2142 \quad$ 2028.1984.tb00697.x

2143 Sponheimer, M., Lee-Thorp, J.A., de Ruiter, D.J., Codron, D., Codron, J., Baugh, A.T., Thackeray, 2144 F., 2005. Hominins, sedges, and termites: new carbon isotope data from the Sterkfontein valley 
2145 and Kruger National Park. Journal of Human Evolution 48, 301-312. $2146 \quad$ https://doi.org/10.1016/j.jhevol.2004.11.008

2147 Sponheimer, M., Passey, B.H., de Ruiter, D.J., Guatelli-Steinberg, D., Cerling, T.E., Lee-Thorp., 2148 J.A. 2006. Isotopic evidence for dietary variability in the early hominin Paranthropus robustus. 2149 Science 314, 980-982. https://doi.org/10.1126/science.1133827

2150 Stammers, R.C., Caruana, M.V., Herries, A.I.R., 2018. The first bone tools from Kromdraai and 2151 stone tools from Drimolen, and the place of bone tools in the South African Earlier Stone Age. 2152 Quaternary International 495, 87-101. https://doi.org/10.1016/j.quaint.2018.04.026

2153 Stanford, C.B., 2001. A comparison of social meat-foraging by chimpanzees and human foragers.

2154 In: Stanford, C.B., Bunn, H.T. (Eds.), Meat Eating and Human Evolution. Oxford University 2155 Press, Oxford, pp. 122-140.

2156 Stanford, C.B., 2012. Chimpanzees and the Behavior of Ardipithecus ramidus. Annual Review of 2157 Anthropology 41, 139-149. https://doi.org/10.1146/annurev-anthro-092611-145724

2158 Stanley, C.Q., Dudash, M.R., Ryder, T.B., Shriver, W.G., Serno, K., Adalsteinsson, S., Marra, 2159 P.P., 2021. Seasonal variation in habitat selection for a Neotropical migratory songbird using 2160 high-resolution GPS tracking. Ecosphere 12(3), e03421. https://doi.org/10.1002/ecs2.3421

2161 Staver, A.C., Hempson, G.P., 2020. Seasonal dietary changes increase the abundances of savanna 2162 herbivore species. Science Advances 6, eabd2848. https://doi.org/10.1126/sciadv.abd2848

2163 Stephens, D.W., Krebs, J.R., 1986. Foraging Theory. Princeton University Press, Princeton (NJ).

2164 Stewart, A.E., Gordon, C.H., Wich, S.A., Schroor, P., Meijaard, E., 2008. Fishing in Macaca 2165 fascicularis: A rarely observed innovative behaviour. International Journal of Primatology 29, $2166 \quad 543-548$. https://doi.org/10.1007/s10764-007-9176-y 
2167 Stewart, K.M., 1994. Early hominid utilisation of fish resources and implications for seasonality 2168 and behaviour. Journal of Human Evolution 27, 229-245. 2169 https://doi.org/10.1006/jhev.1994.1044

2170 Stewart, K.M., 2010. The case for exploitation of wetlands environments and foods by pre-sapiens 2171 hominins. In: Cunnane, S.C., Stewart, K.M. (Eds.), Human Brain Evolution: The Influence of 2172 Freshwater and Marine Resources. John Wiley and Sons, New York, pp. 137-171.

2173 Stewart, K.M., 2014. Environmental change and hominin exploitation of C4-based resources in 2174 wetland/savanna mosaics. Journal of Human Evolution 77, 1-16. 2175 https://doi.org/10.1016/j.jhevol.2014.10.003

2176 Stewart, F.A., Piel, A.K., 2014. Termite fishing by wild chimpanzees: new data from Ugalla, 2177 western Tanzania. Primates 55, 35-40. https://doi.org/10.1007/s10329-013-0362-6

2178 Surbeck, M., Hohmann, G., 2008. Primate hunting by bonobos at LuiKotale, Salonga National 2179 Park. Current Biology 18, R906-R907. https://doi.org/10.1016/j.cub.2008.08.040

2180 Tanaka, J., 1976. Subsistence ecology of Central Kalahari San. In: Lee, R.B., DeVore, I. (Eds.), 2181 Kalahari Hunter-Gatherers. Harvard University Press, Cambridge (MA), pp. 98-120.

2182 Taylor, C.R., Spinage, C.A., Lyman, C.P., 1969. Water relations of the waterbuck, an East African 2183 antelope. American Journal of Physiology 217, 630-634. $2184 \quad$ https://doi.org/10.1152/ajplegacy.1969.217.2.630

2185 Tebbich, S., Sterelny, K., Teschke, I., 2010. The tale of the finch: adaptive radiation and 2186 behavioural flexibility. Philosophical Transactions of the Royal Society: Series B, Biological 2187 Sciences 365, 1099-1109. https://doi.org/10.1098/rstb.2009.0291 
2188 Tennie, C., Gilby, I.C., Mundry, R., 2009. The meat-scrap hypothesis: small quantities of meat 2189 may promote cooperative hunting in wild chimpanzees (Pan troglodytes). Behavioral Ecology 2190 and Sociobiology 63, 421-431. https://doi.org/10.1007/s00265-008-0676-3

2191 Testart, A., 1982. The significance of food storage among hunter-gatherers: residence patterns, 2192 population densities, and social inequalities. Current Anthropology 23, 523-537. 2193 https://doi.org/10.1086/202894

2194 Thompson, J.C., Carvalho, S., Marean, C.W., Alemseged, Z., 2019. Origins of the human 2195 predatory pattern: The transition to large-animal exploitation by early hominins. Current 2196 Anthropology 60, 1-23. https://doi.org/10.1086/701477

2197 Thrash, I., Theron, G.K., Bothma, J.P. 1995. Dry season herbivore densities around drinking 2198 troughs in the Kruger National Park. Journal of Arid Environments 29, 213-219.

2199 https://doi.org/10.1016/S0140-1963(05)80091-6

2200 Trauth, M. H., Asrat, A., Berner, N., Bibi, F., Foerster, V., Grove, M., Kaboth-Bahr, S., 2201 Maslin, M. A., Mudelsee, M., Schäbitz, F. 2021. Northern Hemisphere Glaciation, African 2202 climate and human evolution. Quaternary Science Reviews 268, 107095.

2203 https://doi.org/10.1016/j.quascirev.2021.107095

2204 Tindale, N., 1972. The Pitjandjara. In: Bicchieri, M.G. (Ed.), Hunters and Gatherers Today. Holt, 2205 Rinehart, and Winston, New York, pp. 217-268.

2206 Tomita, K., 1966. The Sources of Food for the Hadzapi Tribe: The Life of a Hunting Tribe in East 2207 Africa. Kyoto University African Studies 1, 157-171.

2208 Tomlinson, D.N.S., 1979. The feeding behaviour of waterbuck in the Lake McIlwaine Game 2209 Enclosure. Rhodesia Science News 13, 11-14. 
2210 Tomlinson, D.N.S., 1981. Effects of the social organization of waterbuck Kobus ellipsiprymnus 2211 ellipsiprymnus (Ogilby 1833) on forage-habitat utilization in a Rhodesian game park. African 2212 Journal of Ecology 19, 327-339. https://doi.org/10.1111/j.1365-2028.1981.tb01070.x

2213 Toth, N. 1987. Behavioral inferences from early stone artifact assemblages: an experimental 2214 model. Journal of Human Evolution 16: 763-787. https://doi.org/10.1016/0047$2215 \quad 2484(87) 90023-6$

2216 Turnbull-Kemp, P., 1967. The Leopard. Howard Timmins, Capetown.

2217 Turner, J.C., 1979. Adaptive strategies of selective fatty acid deposition in the bone marrow of 2218 desert bighorn sheep. Comparative Biochemistry and Physiology 62A, 599-604. 2219 https://doi.org/10.1016/0300-9629(79)90110-5

2220 Uribelarrea, D., Domínguez-Rodrigo, M., Pérez-González, A., Vegas Salamanca, J., Baquedano, 2221 E., Mabulla, A., Musiba, C., Barboni, D., Cobo-Sánchez, L., 2014. Geo-archaeological and 2222 geometrically corrected reconstruction of the 1.84 Ma FLK Zinj paleolandscape at Olduvai 2223 Gorge, Tanzania. Quaternary International 322-323, 7-31. 2224 https://doi.org/10.1016/j.quaint.2013.12.023

2225 US National Research Council on Diet and Health, 1989. Diet and Health: Implications for 2226 Reducing Chronic Disease Risk. National Academies Press, Washington, DC.

2227 Valeix, M., 2011. Temporal dynamics of dry-season water-hole use by large African herbivores 2228 in two years of contrasting rainfall in Hwange National Park, Zimbabwe. Journal of Tropical 2229 Ecology 27, 163-170. https://doi.org/10.1017/S0266467410000647

2230 Van Rooyen, A.F., 1993. Variation in body condition of impala and nyala in relation to social 2231 status and reproduction. South African Journal of Wildlife Research 23, 36-38. 2232 https://journals.co.za/doi/10.10520/EJC116926 
2233 Van Schaik, C.P., Terborgh, J.W., Wright, S.J., 1993. The phenology of tropical forests: adaptive 2234 significance and consequences for primary consumers. Annual Review of Ecology, Evolution, 2235 and Systematics 24, 353-377. https://doi.org/10.1146/annurev.es.24.110193.002033

2236 Vélez, J., Espelta, J., Rivera, O., Armenteras, D., 2017. Effects of seasonality and habitat on the 2237 browsing and frugivory preferences of Tapirus terrestris in north-western Amazonia. Journal 2238 of Tropical Ecology 33(6), 395-406. https://doi.org/10.1017/S0266467417000359

2239 Vincent, A.S., 1985. Plant foods in savanna environments: a preliminary report on tubers eaten by 2240 the Hadza of southern Tanzania. World Archaeology 17, 131-147. $2241 \quad$ https://doi.org/10.1080/00438243.1985.9979958

2242 Vrba, E.S., 1985. Environment and evolution: alternative causes of the temporal distribution of 2243 evolutionary events. South African Journal of Science 81, 229-236.

2244 Watts, D.P., 2020. Meat eating by nonhuman primates: A review and synthesis. Journal of Human 2245 Evolution 149, 102882. https://doi.org/10.1016/j.jhevol.2020.102882

2246 Weissner, P., N!aici, A., 1998. Population, Subsistence, and Social Relations in the Nyae Nyae 2247 Area: Three Decades of Change. Unpublished report submitted to Nyae Nyae foundation, 2248 Windhoek, Namibia.

2249 Winterhalder, B., Smith, E.A. (Eds.), 1992. Evolutionary Ecology and Human Behavior. Aldine 2250 de Gruyter, New York.

2251 Wirtz, P., Kaiser, P., 1988. Sex differences and seasonal variation in habitat choice in a high 2252 density population of waterbuck, Kobus ellipsiprymnus (Bovidae). Zeitschrift für 2253 Säugetierkunde 53, 162-169.

2254 Wood, B.M., Gilby, I.C., 2017. From Pan to Man the Hunter: hunting and meat sharing by 2255 chimpanzees, humans, and our common ancestor. In: Muller, M.N., Wrangham, R.W., Pilbeam, 
D.R. (Eds.), Chimpanzees and Human Evolution. Harvard University Press, Cambridge (MA), pp. 339-382.

2258 Wrangham, R.W., Cheney, D., Seyfarth, R., Sarmiento, E., 2009. Shallow-water habitats as 2259 sources of fallback foods for hominins. American Journal of Physical Anthropology 140, 630642. https://doi.org/10.1002/ajpa.21122

Wynn, T., Hernandez-Aguilar, A., Marchant, L.F., McGrew, W.C., 2011. “An ape's view of the Oldowan” revisited. Evolutionary Anthropology 20, 181-197. 2263 https://doi.org/10.1002/evan.20323

2264 Yang, H., Dou, H., Baniya, R.K., Han, S., Guan, Y., Xie, B., Zhao, G., Wang, T., Mou, P, Feng, 2265 L., Ge. J., 2018. Seasonal food habits and prey selection of Amur tigers and Amur leopards in 2266 Northeast China. Scientific Reports 8, 6930. https://doi.org/10.1038/s41598-018-25275-1

2267 Yoshikawa, M., Ogawa, H., 2015. Diet of savanna chimpanzees in the Ugalla area, Tanzania. 2268 African Study Monographs 36, 189-209. https://doi.org/10.14989/200275

2269 Yravedra, J., Diez-Martín, F., Egeland, C.P., Maté-González, M.Á., Palomeque-González, J.F., 2270 Arriaza, M.C., Aramendi, J., Vargas, E.G., Estaca-Gómez, V., Sánchez, P., Fraile, C., Duque, 2271 J., Rodríguez, S. de F., González-Aguilera, D., Uribelarrea, D., Mabulla, A., Baquedano, E., 2272 Domínguez-Rodrigo, M., 2017a. FLK West (Lower Bed II, Olduvai Gorge, Tanzania): a new 2273 early Acheulean site with evidence for human exploitation of fauna. Boreas 46, 816-830. 2274 https://doi.org/10.1111/bor.12243

2275 Yravedra, J., Maté-González, M.Á., Palomeque-González, J.F., Aramendi, J., Estaca-Gómez, V., 2276 Blazquez, M.S.J., Vargas, E.G., Organista, E., González-Aguilera, D., Arriaza, M.C., Cobo2277 Sánchez, L., Gidna, A., Val, D.U.D., Baquedano, E., Mabulla, A., Domínguez-Rodrigo, M., 2278 2017b. A new approach to raw material use in the exploitation of animal carcasses at BK 
2279 (Upper Bed II, Olduvai Gorge, Tanzania): a micro-photogrammetric and geometric

2280 morphometric analysis of fossil cut marks. Boreas 46, 860-873.

$2281 \quad$ https://doi.org/10.1111/bor.1222 